Dissertação apresentada como requisito parcial para a obtenção do grau de Mestre em Direito, perante o Programa de Pós-Graduação da Faculdade de Direito da Universidade de São Paulo, Departamento de Filosofia e Teoria Geral do Direito.

Professor Orientador: Doutor Celso Fernandes Campilongo

Faculdade de Direito da Universidade de São Paulo

SÃO PAULO 


\title{
HOMO JURIDICUS: TEORIZAÇÃO SOBRE O CONCEITO DE INDIVÍDUO NO ÂMBITO DO DIREITO POSITIVO BRASILEIRO.
}

\author{
Dissertação apresentada como \\ requisito parcial para a obtenção do \\ grau de Mestre em Direito, perante \\ o Programa de Pós-Graduação da \\ Faculdade de Direito da \\ Universidade de São Paulo, \\ Departamento de Filosofia e Teoria \\ Geral do Direito.
}

Professor Orientador: Doutor Celso Fernandes Campilongo

Faculdade de Direito da Universidade de São Paulo

\author{
SÃO PAULO
}




\section{HOMO JURIDICUS: TEORIZAÇÃO SOBRE O CONCEITO DE INDIVÍDUO NO ÂMBITO DO DIREITO POSITIVO BRASILEIRO.}

Dissertação aprovada como requisito parcial para a obtenção do grau de Mestre em Direito, perante o Programa de Pós-Graduação da Faculdade de Direito da Universidade de São Paulo, Departamento de Filosofia e Teoria Geral do Direito.

Orientador:

Professor Doutor Celso Fernandes Campilongo

Departamento de Filosofia e Teoria Geral do Direito - USP

Professor Doutor

Membros

Professor Doutor 


\section{AGRADECIMENTOS}

A idéia de desenvolver um trabalho envolvendo Direito e Economia surgiu no início da década de 90. Havia terminado de concluir a faculdade de Economia e ingressado na pós-graduação, ocasião em que fui aluno do Prof. Ubirantan Iório Jorge de Souza, o “Bira”.

Foi por intermédio do Bira que conheci no Instituto Liberal do Rio de Janeiro o Prof. Og Francisco Leme, um dos maiores pensadores brasileiros, e de quem tive a honra e privilégio de ser amigo e de conviver por onze anos. Com ele estudei Economia e Filosofia.

Semanalmente discutíamos por horas a fio, desde as obras clássicas até as mais modernas, às vezes em sua sala no IL, outras em sua casa, em restaurantes, enfim, em qualquer local que pudéssemos conversar. Provavelmente aqueles que sentavam ao nosso lado, inclusive sua esposa, Maria do Carmo, deveriam achar no mínimo curiosa a nossa conversa.

Roberto Campos, João Paulo dos Reis Velloso, Arthur B. Laffer e Alberto Oliva foram apenas alguns dos intelectuais brasileiros e estrangeiros que conheci e dialoguei na presença e olhar atento do Og. Para um jovem, recém-formado em Economia, no auge dos seus vinte e (muito) poucos anos, poucas experiências poderiam ser tão gratificantes.

Se não fosse por ele muito provavelmente eu teria embarcado para o Japão com o objetivo de cursar outra pós-graduação, desta vez em Economia. Na época tinha sido recomendado para a bolsa do Governo Japonês pelo Mario Henrique Simonsen e por alguns outros professores, mas o Og sempre dizia: "se você quiser estudar Economia, precisa ir para Universidade de Chicago”. Não precisou de muito esforço para que eu mudasse de idéia e desistisse da minha intenção inicial. Todavia, sem desistir de concretizá-la, o que pretendo no futuro. 
Com seu incentivo, por volta do ano 2000 comecei a escrever um livro sobre a história do mercado financeiro brasileiro em co-autoria com Cláudio Haddad. Infelizmente o projeto foi abandonado alguns meses depois por falta de tempo. Mea culpa. Estava numa encruzilhada, onde deveria escolher entre abandonar a minha carreira profissional ou optar pela vida acadêmica. Mas a segurança é sempre um fator relevante quando se tem filhos, e o meu segundo estava a caminho.

Foram onze anos de convivência, diálogo e aprendizado. Arrependo-me de poucas coisas na vida, uma delas é de não ter estado presente na cerimônia de seu falecimento, em 6 de janeiro de 2004, aos 81 anos de vida.

Paralelamente, em 1999, quase quatro anos depois de ter desembarcado em São Paulo, fui apresentado aos professores Carlos Alberto de Bragança Pereira (“Carlinhos”) e Júlio Michael Stern (“Julinho”), ambos do Instituto de Matemática e Estatística da Universidade de São Paulo. Na ocasião eu tinha acabado de deixar meu cargo de Diretor de um grande banco estrangeiro e alçado vôo próprio.

Em pouco tempo Carlinhos e Julinho se tornaram meus amigos e professores. Meu espírito inquieto, aguerrido, briguento e teimoso foi aos poucos sendo domado (mas não tanto!) por eles.

Aprendi muito com eles, não apenas um pouquinho de Ciência, afinal os dois são consagrados professores, mas também a ter paciência e agir com parcimônia. Sou muito grato pelas discussões, broncas, e, sobretudo, pela amizade sincera e presença constante de vocês ao longo de quase dez anos de convivência.

Há muito tempo já flertava com o Direito. Meu interesse surgiu quando ganhei do Og o meu primeiro livro sobre o assunto, chamado Origins of the Common Law, de autoria de Arthr R. Hogue, um dos amigos dele da época em que cursou a Universidade de Chicago, juntamente com Milton Friedman e Frank Knight.

Naquela época, ele sempre mencionava sobre a possibilidade de cursar em conjunto o $\mathrm{PhD}$ em Economia como aluno do programa administrado pelo Committee on Social Tought, em especial como student at large. Porém, ao contrário de meu mentor, eu achava que precisava aprender o Direito de forma sistematizada, mesmo sob pena de adquirir os vícios de um ensino formal de um curso de graduação. 
A mesma falta de tempo que influenciou o abandono do livro como o Cláudio, fez com que eu postergasse o início da graduação em Direito. Porém, quando resolvi cursar a faculdade e ingressei em 2006 na Pontifícia Universidade Católica de São Paulo, não tinha a mais vaga idéia de que conheceria aquele que veio a ser o grande incentivador da minha pesquisa na área, o Prof. Celso Fernandes Campilongo, meu orientador, e a quem devo o presente Mestrado.

Ainda no primeiro ano da graduação, mesmo sem conhecê-lo, entrei na sala em que ele estava finalizando a aula, me apresentei e começamos a conversar sobre minhas idéias, ainda incipientes e desorganizadas.

Em alguns meses, passamos a discutir por e-mail, telefone, em seu escritório ou na faculdade, quando coincidia de encontrá-lo pelos corredores. Fui apresentado à Teoria dos Sistemas, de Niklas Luhmann, e gradativamente à Filosofia e Teoria do Direito.

Não queria perder meu tempo fazendo unicamente a graduação. São cinco anos que podem ser mais bem aproveitados, e cursar uma pós-graduação em Direito vinha de encontro com a minha intenção de cursar o PhD no exterior.

Passado algum tempo, fui convidado para cursar como aluno ouvinte a disciplina Teoria Geral do Direito, ministrada por ele no curso de pós-graduação da PUC. Uma espécie de pré-requisito para tê-lo como meu orientador.

Foi quando tive um vislumbre do esforço que seria necessário para levar a cabo a minha intenção de cursar a pós-graduação juntamente com a graduação. Não seria fácil fazer uma graduação com a seriedade que eu necessitava, e a pós-graduação com o nível de excelência pretendida.

Apesar de ter sido aprovado em todas as fases do processo seletivo para o programa de pós na USP existia o risco de eu não conseguir acompanhar as disciplinas. Afinal, nunca havia estudado sistematicamente o Direito e acabava de concluir o primeiro ano da graduação. 
Reconheço que não foi fácil. Longe disto. Aprender em tão pouco tempo o conteúdo necessário para desfrutar do conhecimento de meus mestres nas disciplinas cursadas não teria sido possível sem muito empenho e noites em claro.

Isso só foi possível pela boa-vontade, sempre presente, disposição de ajudar, e de discutir (mesmo ouvindo as maiores besteiras!). Celso: sou muito grato pelo seu apoio, paciência, presença constante e, sobretudo, por ter apostado em mim. Espero não ter frustrado suas expectativas.

Ao longo do Mestrado tive a oportunidade de cursar diversas disciplinas, na sua grande maioria na Faculdade de Economia, Administração, e Contabilidade e na Faculdade de Direito, ambas da Universidade de São Paulo.

A primeira disciplina na qual me inscrevi na Faculdade de Direito Metodologia de História do Pensamento Jurídico - contou com uma turma pequena, de apenas dez alunos. Foi o meu batismo de fogo. Ainda sob o comando do mesmo professor, cursei outra disciplina, com conteúdo igualmente instigante. Há muito tempo não estudava tanto, com tanto interesse, e participava de discussões tão interessantes.

Nessas duas oportunidades interagi com aquele que, juntamente com o Celso, foi responsável por grande parte da minha formação intelectual no Direito. Foram horas de aula, um número maior ainda de horas estudando, discussões e sugestões de leitura e a oportunidade de participar de debates com outros professores, seus amigos. O Prof. José Reinaldo Lima Lopes.

As disciplinas que cursei na FEA também foram proveitosas e intrigantes. O Prof. Ricardo Abramovay me fez refletir muito sobre minha formação prévia e a influência que tive resultante de meus estudos de autores pertencentes à Escola Austríaca.

A Prof. Ana Maria Bianchi me cativou com os seus conhecimentos em metodologia econômica e história do pensamento econômico, clareza na exposição de idéias, franqueza e habilidade em conduzir discussões. 
Devo bastante à Bianchi e ao Abramovay, mas, certamente, aquele que mais influenciou minha pesquisa em Economia e Filosofia Política foi o Prof. José Raymundo Novaes Chiappin, meu professor na disciplina Economia e Direito.

Discutir Bentham, Descartes, Hobbes, Jevons e Walras, dentre outros autores clássicos, pela óptica da Análise Econômica do Direito, e conduzido por um professor com formação em Física, Filosofia e Economia, foi de grande valia para os meus estudos.

Sem os ensinamentos do Chiappin e os estudos prévios feitos nas disciplinas do José Reinaldo eu não teria encontrado o fio condutor de meu trabalho. É bem verdade que ao Celso coube o papel mais difícil: a orientação necessária para dar coerência às idéias, com sugestões de leitura e diversas discussões.

Não posso deixar de mencionar um professor que se dedica a discutir as influências da sociedade moderna e da Economia no Direito. Apesar de ter lido algumas de suas obras, somente tive a oportunidade de conhecê-lo no final do segundo ano do curso de pós-graduação, quando cursei a disciplina Metodologia do Ensino Jurídico.

O dinamismo, vitalidade, conhecimento, clareza de idéias e franqueza do Prof. José Eduardo Campos de Oliveira Faria são dignos de nota. A ele faço um especial agradecimento.

Quanto às demais disciplinas, até mesmo aquelas que de alguma forma corresponderam às minhas expectativas, todas, sem exceção, contribuíram para a minha formação e estudo, pois sempre é possível encontrar em algum texto uma idéia, argumento ou referência que pode ser aproveitado.

Os meus professores na Pontifícia Universidade Católica de São Paulo também desempenharam um papel imprescindível. Cursar em paralelo a graduação e a pós-graduação não é fácil e poderia ter sido ainda mais difícil. Sem suas exceções, tolerância, apoio e condescendência eu não teria conseguido freqüentar as aulas, encontrar tempo para estudar e fazer trabalhos e seminários.

Gilson Delgado Miranda, Luiz Antônio Castro de Miranda, Luiz Guilherme A. Conci, Mairan Gonçalves Maia Jr., Maurício Sheinman, Renato Rua de 
Almeida, Silvia Saviano Sampaio, Waléria Garcelan Loma Garcia, e Yara Stroppa. Sou grato a vocês. Meu especial agradecimento à Prof. Mara Regina de Oliveira, minha professora do primeiro ano. Sem suas orientações de leitura e indicações bibliográficas, e revisão e correção de meus resumos, a preparação para a prova específica do processo seletivo para a pós-graduação teria sido em muito dificultada.

Agradeço, também, às amizades que fiz ao longo do curso. As intermináveis discussões com Andreia Cristina Bagatin, Frederico Lopes de Oliveira Diehl e Valdemar Bragheto Junqueira muito ajudaram na compreensão de certas idéias e conceitos do Direito e da Filosofia.

Por último, o mais importante. Sem o apoio, carinho e compreensão de minha mulher, Silviane, que está ao meu lado incansavelmente há 17 anos, e de meus filhos, João Vitor e Luiz Fernando, e da ajuda de minha mãe, Maria Lúcia, não teria conseguido ingressar no curso de pós-graduação, terminar meus estudos, e concluir o presente trabalho. 


\section{RESUMO}

Este trabalho objetiva a discussão acerca da possibilidade de se utilizar uma tese ontológica sobre o indivíduo no âmbito do Direito. Em primeiro lugar, é feita uma análise histórica de alguns dos conceitos e termos utilizados corriqueiramente pelo Direito e a presença de incerteza terminológica. No Capítulo 2, discute-se a necessidade de uma tese ontológica de indivíduo e a separação entre raciocínio e racionalidade. O Capítulo 3 é dedicado à análise do arcabouço teórico necessário à compreensão do lugar do Homo juridicus e do Homo oeconomicus. Para este propósito, escolheu-se a teoria dos Três Mundos, de Karl Popper. 


\begin{abstract}
This work aims the discussion about the possibility of using an ontological thesis about the individual in the Law. First, a historical analysis of some of the concepts and terms ordinarily used by the Law along with the presence of terminological uncertainty is made. Chapter 2 discusses the need for an ontological thesis about the individual and the separation between reasoning and rationality. Chapter 3 is dedicated to the analysis of the theoretical background needed to understand the place of Homo juridicus and Homo oeconomicus. For that, Karl Popper's theory of the Three Worlds was chosen.
\end{abstract}


Conteúdo

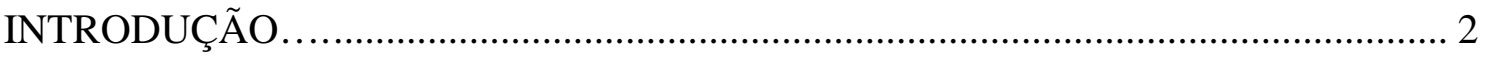

CAPÍTULO 1: Uma tentativa de reconstrução histórica dos conceitos: do oikodespótes ao pater familias, até os dias atuais.................................................... 5

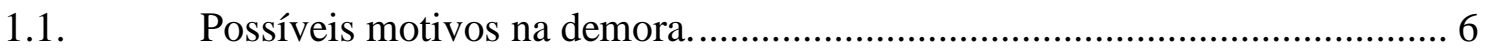

1.2. $\quad$ A (re)introdução do oikodespótes............................................................ 15

1.3. Do oikodespótes para o pater familias.......................................................... 23

1.4. Sobre o (bonus) pater familias propriamente dito.......................................... 27

1.5. A importância da religião doméstica e a origem do Direito Privado. .......... 30

1.6. O pater familias no Direito Pátrio. ................................................................ 33

1.7. A incerteza terminológica: como se chama o pater familias no Direito

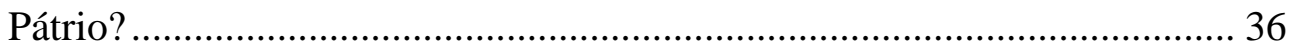

1.8. O Homo oeconomicus historicamente considerado....................................... 45

CAPÍTULO 2: A ausência de um modelo de indivíduo na metodologia jurídica e

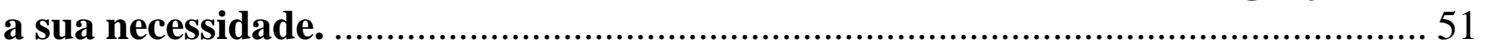

2.1. Homo juridicus: algumas tentativas incompletas........................................ 51

2.1.1. As posições de Del Vecchio e de Supiot. ............................................................51

2.1.2. Homo juridicus e Homo oeconomicus como entidades comunicativas.........53

2.2. A necessidade de um modelo de indivíduo ............................................... 58

2.3. A pessoa como destinatária do direito posto. …………………………….... 67 
2.4. Raciocínio jurídico versus racionalidade jurídica: plano concreto versus plano abstrato. 71

2.5. Os diferentes tipos de racionalidade jurídica. 84

2.6. $\quad$ Os diferentes tipos de decisão. 93

CAPÍTULO 3: A teoria de Karl Popper como explicação e demarcação. .......... 105

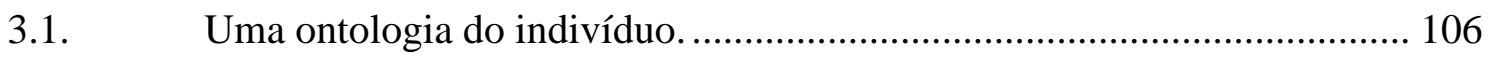

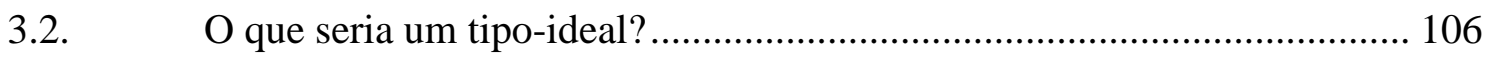

3.3. O individualismo metodológico: o tipo-ideal individualizado.................. 108

3.4. A Lógica Situacional: o autismo acaba aqui........................................ 115

3.5. O egoísmo ético: o homem deveria ser egoísta, mas não é. …................... 116

3.6. Racional, nem que seja de “mentirinha”............................................ 117

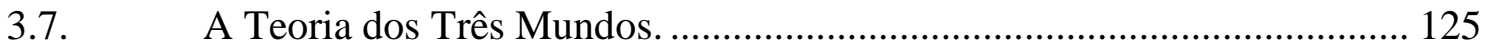

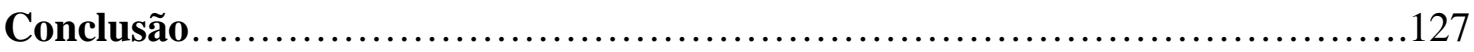

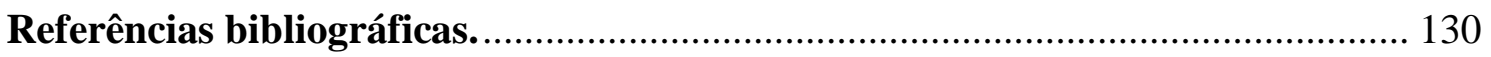




\section{INTRODUÇÃO}

Uma breve revisão das obras de metodologia jurídica é suficiente para constatar a inexistência de menção sobre um modelo de indivíduo para o Direito.

Apesar disso, ocupa-se a doutrina jurídica em teorizar sobre a decisão judicial, empregando grande esforço para discutir a racionalidade atribuível ao Julgador $^{1}$ de carne e osso, e a realização do Direito, enquanto o legislador edita normas para regular a vida em sociedade.

Procura-se, com o presente trabalho, endereçar estas situações e desenvolvê-las, para concluir com a proposta de utilização do Homo oeconomicus como tese ontológica de indivíduo para o Direito, pelo menos enquanto outra não tome o seu lugar.

Parte-se da hipótese de que a doutrina jurídica não se ocupa em elaborar qual seria a tese ontológica de indivíduo, a qual nortearia o Direito, quer pela formulação de teorias, quer pela criação de normas jurídicas no seu sentido mais amplo.

É de se estranhar o fato de que, sendo o Direito uma Ciência Humana, tal como o é a Economia, ao contrário desta última, este não possua um modelo de indivíduo que possa ser utilizado como referência na formulação de enunciados.

Enunciados estes que serviriam para o desenvolvimento de teorias e, com isso, desenvolver ainda mais o Direito. Reconhece-se, porém, a proposta da Teoria dos Sistemas e a possibilidade de se teorizar sobre a função do Direito colocando o ser humano em segundo plano, o que, de certa forma, conflitaria com o aqui proposto.

Tendo em consideração este vazio deixado pela Teoria do Direito mais tradicional, a proposta da presente pesquisa envolve investigar quais seriam os modelos de indivíduo que podem ser tradicionalmente encontrados para o Direito, de modo a

\footnotetext{
${ }^{1}$ Para o propósito do presente trabalho, integram o conceito de Julgador os magistrados, árbitros, órgãos colegiados com poder judicante e todos os demais que exerçam a função judicante pelo Estado ou em seu lugar. Mesmo quando for representado por uma coletividade, será sempre um conjunto de indivíduos que pode ser reduzido a sua singularidade. Logo, o Julgador será sempre um indivíduo.
} 
aproximá-los com a tese ontológica de indivíduo em uso pela Economia. Para tanto, o presente trabalho está dividido em quatro capítulos, além desta introdução e da conclusão.

Em primeiro lugar, é feita uma análise histórica de alguns dos conceitos e termos utilizados corriqueiramente pelo Direito e a presença de incerteza terminológica. São analisados o oikodespótes e o pater familias, bem como, é feito um breve sumário histórico do Homo oeconomicus. O objetivo é apresentar a continuidade histórica entre os conceitos e as semelhanças existentes eles.

No Capítulo 2, discute-se a necessidade de uma tese ontológica de indivíduo, analisa-se a pessoa como destinatária do Direito e apresentam-se algumas considerações acerca do Homo juridicus que podem ser encontradas na literatura. Busca-se, com isto, demonstrar que os usos em curso do Homo juridicus são insuficientes para constituir a tese ontológica de indivíduo. O mesmo pode ser dito sobre a pessoa, que, apesar de ser igualmente uma ficção, mas, no caso, jurídica, não serve para este propósito.

Discute-se também a separação entre raciocínio e racionalidade, bem como, são introduzidos os tipos diferentes de decisão que podem ser encontrados no Direito. Primeiramente, sustenta-se que o raciocínio se encontra no plano do ser humano, enquanto racionalidade somente pode ser atribuída a entidades abstratas.

Esta separação é importante para aclarar a necessidade de uma tese ontológica de indivíduo. Além disto, serve para demonstrar que o próprio legislador se incumbiu de positivar aspectos metodológicos essenciais para toda e qualquer tese ontológica a ser utilizada no âmbito do Direito.

O Capítulo 3 é dedicado à análise do arcabouço teórico necessário à compreensão do lugar do Homo juridicus e do Homo oeconomicus, duas entidades abstratas de cunho unicamente metodológico utilizadas na formulação dos enunciados que suportarão o desenvolvimento de teorias no âmbito do Direito. Para este propósito, escolheu-se a Teoria dos Três Mundos, de Karl Popper. 
Da mesma forma, são apresentadas algumas das características necessárias à tese ontológica de indivíduo para o Direito e uma forma possível para se flexibilizar o autismo característico do Homo oeconomicus. Neste sentido, utiliza-se a Lógica Situacional, outra teoria de Popper.

Em seguida, é apresentada a conclusão e, por último, a bibliografia. 


\section{CAPÍTULO 1: UMA TENTATIVA DE RECONSTRUÇÃO HISTÓRICA DOS CONCEITOS: DO OIKODESPÓTES AO PATER FAMILIAS, ATÉ OS DIAS ATUAIS.}

O presente trabalho começa pela tentativa de reconstrução histórica de um dos conceitos mais enraizados no Direito de tradição romano-germânica - o (bonus) pater familias - e também com uma afirmação: o Direito não possui um modelo ${ }^{2}$ de indivíduo em seu centro.

A dificuldade que se encontrou nesta reconstrução se deve ao caráter essencialmente argumentativo do Direito, o que prejudica a determinação do conteúdo de certos conceitos, não apenas deste que se busca reconstruir.

Para supri-la, buscou-se primeiramente entender a sua evolução histórica para, posteriormente, seguir o mesmo caminho trilhado pela Economia até o surgimento do Homo oeconomicus.

Durante a tarefa de reconstrução, identificou-se a proximidade entre o pater familias e o Homo oeconomicus por conta de uma raiz comum: o oikodespótes.

Neste sentido, aproveitar-se-á da semelhança entre o pater familias e o oikodespótes, e da semelhança entre estes e o medieval “L’Economo prudente”. Além desta semelhança, far-se-á uso da afirmação de que este último seria um ancestral ou uma antecipação do Homo oeconomicus.

Semelhança e afirmação, juntas, fornecerão os elementos necessários para permitir argumentar pela possibilidade de utilização do conceito de Homo oeconomicus no Direito em substituição do conceito de pater familias.

O Homo oeconomicus assumiria, assim, os contornos de Homo juridicus.

\footnotetext{
${ }^{2}$ Escolheu-se, por enquanto fazer referência a um “modelo de indivíduo” ou a um "tipo-ideal” ao invés de se utilizar "tese ontológica”. Esta substituição somente ocorrerá no Capítulo 3 com a apresentação da Teoria do Três Mundos, de Karl Popper.
} 
Os argumentos necessários para criar as ligações que sustentam a afirmação acima estão como frutos maduros prontos para serem colhidos, apesar das poucas fontes disponíveis. Mesmo assim, não será necessário grande exercício para aclarar a ligação existente entre oikodespótes, pater familias, oeconomia e Homo oeconomicus.

Todavia, é necessário destacar que este “novo” Homo juridicus de nada se aproxima de seus antecessores, os quais podem ser encontrados nas obras de Del Vecchio e Supiot.

Em seguida, serão apresentadas algumas das tentativas que podem ser encontradas na literatura com o intuito de se criar um modelo de indivíduo no Direito Pátrio. Para esta criação serão utilizados os elementos existentes na doutrina.

\subsection{Possíveis motivos na demora.}

De certa forma, a aproximação entre oikodespótes e pater familias é bastante evidente quando se dá um passo atrás e procura-se entender onde estes surgiram e as funções que desempenhavam nas sociedades de suas épocas.

A principal dimensão decorrente das funções inerentes ao papel social de ambos é a patrimonial; o que permitiria, com certa facilidade, a aproximação com o Homo oeconomicus. Porém, não foi isto que se verificou na doutrina jurídica mais tradicional e duas podem ser as justificativas para esta demora.

Em primeiro lugar, tradicionalmente, os autores das obras de Direito Romano no Brasil dão ao conceito de família determinada ênfase, à qual direcionou seu uso e não expressa toda a complexidade do conceito de família para gregos e romanos.

É possível dizer que o uso moderno do termo não corresponde ao seu uso antigo, o que pode ser explicado. A doutrina estrangeira também seguiu este mesmo caminho, conforme aponta Richard P. Saller. 
“A comprehensive survey of all uses of pater familias in classical texts, however, reveals a major disjunction between this modern understanding of the term (rooted in Roman Law) and ancient usage”, Saller (1999:182).

O processo de transposição temporal do papel social desempenhado pelo pater familias não levou em conta a integralidade das funções por ele desempenhadas, deixando de lado certa dimensão de suas ações, mas dando ênfase à outra: a jurídica. Mesmo a dimensão jurídica somente ressaltou os aspectos relacionados ao padrão de conduta para a verificação do dever de indenizar e aos laços familiares.

Houve, assim, um processo de cherry picking empregado pelos doutrinadores para selecionar algumas características do pater familias a fim de transpôlo para a sociedade brasileira, em especial a partir do século passado.

Com isto, ocorreu aparente desconsideração da estrutura social e de aspectos sócio-culturais da sociedade romana e, mais ainda, das influências exercidas na formação do Direito em Roma, conforme aponta Max Weber.

“Em particular, é difícil estabelecer se não só a grande propriedade imobiliária, mas também a economia agrícola em grande escala orientaram as instituições jurídicas especiais e, se o fizeram, por que caminhos as conduziram”, Weber (1994:186).

Não se pode dizer que a determinação do padrão de conduta reflete a dimensão patrimonial das funções do pater familias, por mais que esteja relacionada com o trato de bens e direitos, os quais possuem obrigatoriamente expressão econômico-financeira e, conseqüentemente, patrimonial.

Esta dimensão, deixada de lado pelos doutrinadores, é central ao entendimento do pater familias; sendo, por assim dizer, a sua essência. Isto porque, para ser um pater familias não significava, obrigatoriamente, possuir uma família constituída com descentes. 
A problemática acerca da transposição temporal durante a tradução de obras em outros idiomas e de épocas remotas é digna de nota. Não raro, equívocos são cometidos. Isto porque, tradutor e pesquisador sempre enxergarão a época sob análise através de lentes que refletem a sociedade na época em que vivem, por mais isentos e disciplinados que possam ser neste processo. Ou seja, o ponto de vista será sempre do futuro para o passado.

Tais lentes são repletas de conceitos, valores, usos e costumes que estão sob influência do referencial temporal e, por maior que seja o esforço para eliminar esta influência, ela, em maior ou menor grau, contaminará o resultado final.

Para melhor ilustrar esta problemática, pede-se licença a Neil MacCormick. O autor apresenta uma das passagens da obra “As Viagens de Gulliver” para discutir o ponto de vista interno e o ponto de vista externo das normas proposto por H. L. A. Hart.

Nesta passagem, os habitantes de Lilliput desconhecem o que seria um relógio e interpretam o objeto como sendo um animal desconhecido ou algo divino, Maccormick (2006:359-381).

Para aqueles que já tiveram algum contato com um relógio, por mais simples que possa ser o objeto, tal aproximação pode parecer absurda. Porém, não se pode esquecer que os habitantes daquela ilha não possuíam a noção do que seria um relógio; nunca haviam visto um, nunca haviam usado um.

Se for assumido que Gulliver se encontrava no futuro e os habitantes de Lilliput no passado ou em alguma sociedade imune aos efeitos do progresso, reações similares seriam obtidas se fosse introduzido nesta sociedade qualquer objeto desenvolvido por uma sociedade mais avançada.

O mesmo pode ser dito de profissões e papeis sociais. Ao passo que, resquícios do passado podem não parecer tão estranhos no futuro. A roda não foi inventada nos dias atuais. O carpinteiro não surgiu ontem. Já fazem parte da memória da 
sociedade ou do grupo social, a qual foi progressivamente alterada com o progresso social.

Por sua vez, profissões e objetos recentes não encontrariam correspondentes naquelas sociedades, mas, eventualmente, poderiam existir outros com funções similares.

O automóvel e os cargos políticos seriam alguns exemplos. Podem até serem semelhantes se comparadas unicamente com as funções desempenhadas, como exemplo, com a carroça e os senadores. Mas esta semelhança não expressa a complexidade de sentidos que possuem e a importância social de cada um deles.

Conforme dito, equívocos são cometidos, o que acaba por prejudicar o entendimento e o desenvolvimento. Não se discute que certas profissões atuais não existiam no mundo antigo, mas, mesmo nos dias atuais ainda existem equívocos quanto à sua importância, função e dimensão.

Para exemplificar como o futuro contamina o passado no processo de tradução de um texto que reflete a estrutura social de uma época pretérita, toma-se, por exemplo, a tradução da obra “Górgias”, de Platão, feita por Carlos Alberto Nunes.

“452a Sócrates - É que poderias ser assaltado agora mesmo pelos profissionais dessas coisas elogiadas pelo autor da cantilena, a saber, o médico, o pedótriba e o economista, e falasse em primeiro lugar o médico: Sócrates, Górgias te engana; não é sua arte que se ocupa com o melhor bem para os homens, porém a minha”, Platão (2002:134). Em outra passagem, na mesma obra, “471e Sócrates Criatura bem-aventurada! Procuras convencer-me com recursos de oratória, como nos tribunais costumam fazer os advogados”, Platão (2002:163).

Fazendo uma primeira comparação das passagens acima com a reconhecida tradução de Benjamin Jowett.

Na primeira passagem,"Soc. I mean to say, that the producers of those things which the author of the song praises, that is to say, the physician, the trainer, the 
money-maker, will at once come to you, and first the physician will say: 'O Socrates, Górgias is deceiving you, for you my art is concerned with the greatest good of men and not his'”, Jowett (1892, v.2:331). Na segunda passagem, “Soc. Not so, my simple friend, but because you will refute me after the manner which rhetoricians practice in courts of law”, Jowett (1892, v.2:355).

Por último, em outra tradução, desta vez de John M. Cooper, a primeira passagem teria a seguinte redação.

"SOCRATES: Suppose that the producers of the things the songwriter praised were here with you right now: a doctor, a physical trainer, and a financial expert. Suppose that the first doctor said, 'Socrates, Gorgias is telling you a lie. It isn't his craft that is concerned with the greatest good for humankind, but mine'”, Cooper (1997:797). Enquanto a segunda passagem, seria lida da seguinte maneira, "SOCRATES: My wonderful man, you re trying to refute me in oratorical style, the way people in law courts do when they think they`re refuting some claim”, Cooper (1997:815).

A despeito das demais diferenças entre a tradução brasileira e as traduções estrangeiras, sobressaem aos olhos o tratamento dado pela primeira. Enquanto, nesta, há menção à profissão de economista, o primeiro estrangeiro traduziu por money-maker enquanto o segundo por financial expert. Seguindo a mesma ordem, novamente é feita menção a outra profissão, desta de advogado. Com relação a esta, o primeiro estrangeiro a traduziu por rhetoricians e o segundo por people in law courts.

Pode-se dizer que o pater familias como é visto hoje, é fruto de uma interpretação limitada, ou até mesmo equivocada, por conta do ponto de vista da análise feita da sociedade antiga.

Como se não bastasse, tradicionalmente procura-se identificar como são tratadas situações, termos, expressões e conceitos em outros países. Em especial naqueles que sofreram influências similares as sofridas pelo Direito Pátrio durante seu processo de desenvolvimento histórico e formação. Esta seria a última justificativa. 
Dentre os países cuja influência pode ser notada com bastante freqüência na doutrina nacional mais tradicional, encontram-se os situados na Europa continental, com destaque à Alemanha e à França. Ambos, juntamente com o Direito brasileiro, convergem para uma herança comum: o Direito Romano.

Freqüentemente, são feitas referências a diplomas legais, textos históricos e obras cujo objetivo é a criação de certa continuidade histórica. O propósito desta continuidade é atribuir certa aparência de estabilidade. A estabilidade permitiria o seu uso em determinado momento, e para determinada finalidade. E este uso faria com que paulatinamente fossem incorporados pela linguagem e discurso - ambos limitados ao âmbito jurídico.

Contudo, ao longo deste processo, alguns aspectos são deixados de lado, pois, nem todos fazem parte do escopo pretendido inicialmente ou da ênfase que se pretende dar. Isto justificaria o esquecimento da dimensão patrimonial do pater familias em detrimento de outras, ainda encontradas na doutrina jurídica pátria.

Com o uso ao longo dos anos, o elo histórico criado - uma cola por assim dizer - apesar de frágil, se solidifica. Desta forma, assume um caráter de quase-dogma, livre de questionamentos, e a integrar o senso comum do Direito.

A partir deste ponto, raramente há contestação ou revisão, enquanto sua reconstrução histórica é sobremaneira dificultada. É neste ponto que a doutrina jurídica pátria se encontra. O pater familias reina absoluto e eternamente no limbo.

Pode-se dizer que os juristas, especialmente os civilistas, na construção da doutrina jurídica brasileira depois da edição do Código Civil de 1916 e utilizando-se de sua erudição característica, buscaram estabelecer relação de correspondência entre o antigo (bonus) pater familias e os textos legais de épocas mais modernas.

Com a entrada em vigor do Código Civil de 2002, a mesma busca por relações de correspondência, já solidificadas pelos doutrinadores anteriores, continuou alimentando a tradição. E o (bonus) pater familias é fruto desta tradição. 
Seria desnecessária a análise da doutrina de Direito Romano para facilmente concluir que não há correspondência entre a sociedade atual e o conhecimento que é trazido pelos romanistas sobre o pater familias. Todavia, ao contrário, há grande correspondência entre romanistas e civilistas. Com relação ao pater familias, civilistas e romanistas criaram um universo paralelo, longe dos efeitos da história e dissociado dos aspectos sociais.

O uso do termo (bonus) pater familias há muito se distanciou de sua origem, apesar de a sociedade brasileira ter sido fundada e se desenvolvido durantes séculos por diversos pater familias.

A influência experimentada pela sociedade brasileira ao longo de seu processo colonizador vai nesta mesma linha. Decorre de alguns, que aqui vieram e trouxeram consigo a cultura predominantemente européia carregada da herança romana, e outros que são genuinamente nacionais, frutos da cultura que surgiu no Brasil colônia com a mistura e o sincretismo de diversas culturas. Veja-se o que diz Gilberto Freyre.

“O absolutismo do pater familias na vida brasileira - pater familias que na sua maior pureza de traços foi o senhor da casa-grande de engenho ou de fazenda foi se dissolvendo à medida que outras figuras de homem criaram prestígio na sociedade escravocrática: o médico, por exemplo; o mestre-régio; o diretor de colégio; o presidente de província; o chefe de polícia; o juiz; o correspondente comercial”, Freyre (2004:238).

Os doutrinadores brasileiros se esqueceram da essência do pater familias - a dimensão patrimonial - esvaziando-o e limitando-o aos aspectos familiares, mesmo que para isso seja necessário esquecer-se das diferenças entre a família romana e a família dos tempos atuais, incluindo-se a brasileira.

Não se ignora a possibilidade de nações, onde a sociedade patriarcal ainda hoje é presente e a religião exerce grande influência, possam possuir maior proximidade com a sociedade romana antiga e, por conseguinte, o pater familias estaria mais bem preservado, um fóssil vivo por assim dizer. 
Esta seria uma importante conseqüência do processo de formação da sociedade, em especial por conta do longo e importante papel por ele desempenhado. Em algumas, tal a sua importância, que o enfraquecimento de sua influência não é tão simples e direto. É o caso da sociedade brasileira, onde ainda existem resquícios do patriarcalismo e do pater familias, conforme aponta Freyre.

“Menos absorvente não só em relação com os poderes da coroa como em relação aos poderes da Igreja, com os quais passaria a constituir simbioticamente, novo complexo. Esse novo complexo, menos puramente patriarcal que nos dois ou três primeiros séculos de formação brasileira, porém, ainda, predominantemente patriarcal. Pois a desintegração de força tão enorme como aquela em torno da qual se constituiu o Brasil não poderia deixar de ser lenta. Tão lenta que não nos é possível dizer do complexo patriarcal que desapareceu do Brasil. Nossas casas ainda são povoadas por sobrevivências patriarcais. Nossos hábitos, ainda tocados por elas. Donde não se poder tentar no Brasil obra de sociologia genética que não seja um estudo do patriarcalismo ou do familismo tutelar sob alguma de suas formas”, Freyre (2004:100).

Independentemente da existência de tais diferenças e sendo limitado à família, não há mais como sustentar a perpetuação do pater familias nem defender a manutenção de seu lugar na sociedade brasileira atual.

Dois argumentos seriam suficientes para sustentar esta posição, não apenas para o Brasil. Primeiro, a retirada do fundamento teológico do Direito, com sua substituição pelo Estado. Esta situação é comum a outros Países, em especial naqueles onde se estabeleceu o Positivismo Jurídico.

Segundo, os movimentos sociais que entre outros trouxeram a igualdade entre o homem e a mulher na sociedade e na família e a igualdade entre as raças - todas conquistadas com grande luta. Estas igualdades são reconhecidas pelo Direito Pátrio, 
em especial estando homem e mulher em pé de igualdade com relação a direitos e deveres da sociedade conjugal ${ }^{3}$.

Se na sociedade de outrora era um papel social de relevo, nos dias atuais, possui papel menos nobre e limitado. Pode-se dizer que unicamente retórico.

O bonus pater familias é um lugar comum ou um topoi, conforme ressalta Tércio Sampaio Ferraz Jr, variável no tempo e no espaço, e cujo conteúdo e os limites são mutáveis e flexíveis. Ele serve como mais um instrumento à disposição do profissional do Direito, Ferraz Jr (2003:329).

O estabelecimento de seu conteúdo e limites fica em grande parte de responsabilidade de quem dele faz uso. Por sua vez, os seus utilizadores se empenham constantemente em construí-lo e destruí-lo de acordo com seus próprios interesses, mas cabendo ao Julgador a última palavra, aceitando o que foi trazido ou apresentando a sua própria versão.

Não haveria, portanto, critério estável e confiável para a sua determinação, posto que o conteúdo e os limites não seriam estáveis, mas sim mutáveis e dependentes de características próprias de cada Julgador e conflito. Afinal, não há dois Julgadores iguais, como também dificilmente há dois conflitos totalmente idênticos.

Como conseqüência desta instabilidade, a priori não seria possível prever resultados, o que, ao contrário, se fosse possível, ofereceria maior segurança às decisões. Seria decorrente característica ao próprio Direito e que nasce de sua própria natureza argumentativa, a qual dificilmente encontra limites, pois não raro extravasa o próprio conteúdo dogmático da norma jurídica, se refugiando em elementos extrajurídicos e estranhos ao Direito Positivo, respaldando-se na necessidade de atualizar este último e de a ele conferir maior correspondência com a realidade social.

\footnotetext{
${ }^{3}$ Constituição Federal de 1988, art. 226, § 5: “Os direitos e deveres referentes à sociedade conjugal são exercidos igualmente pelo homem e pela mulher.”
} 
Assim, seu papel e uso seriam essencialmente na construção do discurso com a função de possibilitar a contraposição de opiniões e a decisão judicial com o intuito de se pôr fim ao conflito de interesses sob análise

Outra forma de ver seria a necessidade de o Direito, enquanto manifestação de Poder, tratar exceções e fornecer respostas à sociedade para situações que fogem o padrão de normalidade para a qual o Direito Positivo foi concebido, e que igualmente necessitam de resposta do Estado, em especial para manter a sociedade sob controle. Não se ignora a necessidade de se ter uma "válvula de escape”.

Entretanto, por mais que se reconheça ser o bonus pater familias um lugar comum, um topoi ou um conceito aberto, resta-lhe a função decorrente da dimensão patrimonial, a qual se encontra presente ainda hoje. É esta dimensão que, mais adiante, fornecerá o elo com o Homo oeconomicus.

Mesmo o seu uso estando limitado ao discurso, ao contrário do que se esperaria, não há esforço em manter estável a terminologia utilizada para definir igualmente o padrão de culpa in abstrato. É o que se verifica, pois, com o passar dos anos, surgiram outras terminologias que foram igualmente utilizadas, acarretando em instabilidade terminológica.

\subsection{A (re)introdução do oikodespótes.}

A despeito da reconhecida influência do pensamento grego no desenvolvimento das instituições romanas, dentre elas o Direito, e de sua importância no pensamento romano e ocidental, a doutrina jurídica pátria, pelo menos nas obras analisadas, não dá a devida atenção ao oikodespótes. O mesmo pode ser dito da ligação entre o Homo oeconomicus e o pater famiílias.

Apesar disto, na doutrina jurídica pátria pode ser encontrada ao menos uma associação entre bonus pater familias e Homo oeconomicus, mas não há indicação do motivo pelo qual tal associação foi feita.

Veja-se o que disse Alvino Lima, "o tipo abstrato, o bonus paterfamilias, o homem avisado, diligente ou economicus, que é o tipo de comparação, deve ser 
conhecido e apreciado pelo autor do dano, para que se possam pedir contas de seu ato, uma vez transviado do caminho que segue este (...)”, Lima (1938:45).

Ficou subentendido o motivo pelo qual foi feita a associação - acertada, diga-se de passagem - entre o bonus pater familias e o Homo oeconomicus. Como relação a esta associação podem ser feitas duas especulações a respeito.

Primeiro que as funções desempenhadas por um e pelo outro são as mesmas, ou muito similares, ainda que restritas ao âmbito do Direito Civil. Segundo, traria consigo a premissa de que pater familias e oikodespótes são historicamente embriões do Homo oeconomicus.

Isto se explicaria, pois as duas convergem para um ponto central: a semelhança entre o papel social ocupado pelo pater familias e o ocupado pelo oikodespótes nas suas respectivas sociedades. E, na sociedade atual, esta função seria abstratamente representada pelo Homo oeconomicus.

Pater familias e oikodespótes tiveram origem no mesmo recinto: o lar, a casa. Domus para os romanos, onde reinava o primeiro; e oikos para os gregos, onde imperava o segundo. Tanto em Roma quanto na Grécia a função decorrente do papel social desempenhado pelos dois era a gestão (ou administração) prudente do lar, da casa.

Dessa gestão prudencial surgiu a oikonomia, dos gregos, ou a oeconomia, dos romanos, que na Grécia antiga, segundo Marilena Chauí, era vista como o “estudo das formas e relações de propriedade, do trabalho e da produção da riqueza e de sua circulação (...)”, Chauí (2003:468).

A semelhança na gestão do lar entre gregos e romanos é, em parte, explicada pela incorporação, pelos romanos, da cultura grega durante o período Clássico, o mesmo pode ser dito com relação ao Direito. Este sofreu influências de Platão e Aristóteles, além dos estóicos, Villey (2005:67). 
Diversas são as fontes que vão neste mesmo sentido, e Paul Veyne é bastante esclarecedor com relação à influência das instituições gregas no Império Romano.

“O Império Romano é a civilização helenística nas mãos brutais (...) de um aparelho de Estado de origem italiana. Em Roma, a civilização, a cultura, a literatura, a arte e a própria religião provieram quase inteiramente dos gregos ao longo do meio milênio de aculturação; desde sua fundação. Roma, poderosa cidade etrusca, não era menos helenizada que outras cidades da Etrúria. Se o alto aparelho de Estado imperador e Senado - permaneceu, no principal, estranho ao helenismo (tal era a vontade de poder entre os romanos), em contrapartida o segundo nível institucional, o da vida municipal (o Império Romano formava um corpo cujas células vivas consistiam em milhares de cidades autônomas), era inteiramente grego. Desde o século II antes de nossa era, a vida de uma cidade do Ocidente latino era idêntica à de uma cidade da metade oriental do Império. E na essência essa vida municipal, completamente helenizada, servia de quadro para a vida privada. (...) Roma tornou-se grega, exatamente como o Japão contemporâneo se tornou um país do Ocidente”, Veyne (2009, v.1:13).

Séculos depois, já na Idade Moderna, os recursos necessários para a subsistência da família ainda eram escassos e a economia era fundamentalmente familiar e patriarcal.

O pater familias continuava todo-poderoso, apesar dos avanços da Igreja, e os seus poderes, juntamente com o status de chefe, somente eram perdidos com a sua morte. Os filhos continuavam sob seu poder, da mesma forma que o patrimônio familiar. Os negócios da família eram por ele conduzidos e a mulher continuava a desempenhar um papel secundário, salvo se fosse viúva ou pertencesse a uma classe social superior, Castan (2009:409-410).

Assim, como na época do Império Romano e na Grécia Antiga, ele continuava responsável pela administração prudente da casa, do lar. O bom funcionamento da casa dependia da peças necessárias à habitação de seus membros, 
quase sempre em grande número, e dos meios e ferramentas para a produção que garantiria a subsistência do grupo familiar, Collomp (2009:503-506).

Pelo lado da Economia, Jean Alois Schumpeter, de certa forma, fez associação similar. Para isto, ele partiu da função social desempenhada.

De acordo com ele, "I. In the sixteenth century and even later, Oeconomia still meant household management. This type of literature seems to have been extremely popular. The no doubt unreliable method of browsing among books of this sort did not yield anything that would qualify for notice in this history. But two samples may be mentioned: first, the famous Oeconomia ruralis et domestica (15931607) by Johann Colerus, which lived for over a century and contains all sorts of advice about housekeeping, including farming, gardening, and domestic medical practice; second, L'Economo prudente (1629) by B. Frigerio, who defined economia as 'a certain prudence with which to govern a family' (ch. IX, for instance, deals with the governo of one's wife) and might conceivably interest some economists because it attempts to describe national economic behavior-in fact its concept of the economo is a commonsense forerunner of the concept of the Economic Man. Similarly, B.Keckermann, Systema disciplinae politicae (1606) defined Oeconomia as disciplina de domo et familia recte dirigenda”, Schumpeter (1986:151).

As obras mencionadas por Schumpeter não são as únicas. Algum tempo depois da obra de Frigerio, a obra L'economia del cittadino in villa, de Vicenzo Tanara, foi publicada, mas precisamente em 1661. A obra de Tanara é direcionada ao pai de família, com o propósito de auxiliá-lo no governo da casa, cobrindo diversos aspectos, entre eles a agricultura e a conservação de mantimentos.

As obras de Colerus, Keckermann, Frigerio, e Tanara foram publicadas num curto espaço de tempo para a época e deixam clara a preocupação e a grande importância dada à gestão da casa. Possivelmente não são as únicas. São obras que não apenas são direcionadas às funções do pater familias medieval na gestão prudente da casa, mas que tratam com grande proximidade daquelas funções que posteriormente foram atribuídas ao Homo oeconomicus moderno, ou seja, a gestão de recursos 
escassos. Conforme o próprio Schumpeter salientou e pode ser visto na passagem acima.

Tal como o pater familias, o L'Economo prudente era responsável pela administração da casa, estando diretamente ligado com o conceito de Economia vigente, ao qual, pode-se adicionar, pouco se alterou. Em certos aspectos, mesmo atualmente, tais funções ainda existem, todavia compartilhadas entre homem e mulher.

Ainda durante o Império Romano os poderes do pater familias foram sendo paulatinamente reduzidos, em parte com o surgimento e desenvolvimento do catolicismo. Mas foi com o surgimento da Filosofia Política e do Estado Moderno que ele perdeu o seu principal sustentáculo: a religião doméstica. Ela era que fornecia o fundamento de validade para os poderes exercidos pelo pater familias e abençoava o seu patrimônio.

No período compreendido entre os séculos XVI e XVII houve a ruptura com a tradição aristotélica. A mesma que possivelmente influenciou as obras sobre a gestão do lar. Paralelamente as discussões sobre a origem do Estado e seus fundamentos ganhavam força nesta mesma época.

Neste rumo, Nicolau Maquiavel forneceu o fundamento filosófico da política moderna na obra “O Príncipe”, publicada em 1513. Com ele, o processo iniciado com a tradução das obras de Aristóteles para o latim chega ao fim. Depois dele, a política se divorcia da sua tradição aristotélica, afastando-se da moral e da ética, e passa a ser vista como uma disciplina autônoma.

Foi nesta época de ruptura que surgiu e se consolidou o termo “economia política”. De acordo com James E. King, este termo já havia sido utilizado em 1611 na obra "La monarchie aristodemodémocratique", de Louis de Mayerne-Turquet, apesar de alguns autores erroneamente terem atribuído o surgimento do termo a Antoine de Montchréstien, que em 1615, publicou o “Traité de l'économie politique”. O fato é que a primeira era um tratado político, enquanto o segundo, um tratado de Economia. 
Thomas Hobbes, ao desenvolver o fundamento filosófico do Estado Moderno com o seu “Leviatã", em 1651, retirou o fundamento teológico do poder. Deslocou-o para o soberano e fundamentou-o no pacto entre os homens, que concordam em reduzir a sua liberdade individual em prol das condições necessárias para a obtenção da segurança e para garantir a ordem - a ordem política da sociedade civil - de modo a evitar o estado de natureza, onde impera a guerra de todos contra todos. A redução de um direito (a liberdade) como forma a possibilitar o outro (a vida), para Hobbes, decorre da razão - da escolha racional.

Como conseqüência da argumentação de Hobbes, ao criar o Estado, os atos do soberano são, em última análise, os atos dos próprios súditos. A segurança, para Hobbes, não deve ser entendia por "uma simples preservação, como também todos os outros confortos da vida, que cada homem, por esforço lícito, sem perigo ou inconveniente para a república adquire para si próprio”, Hobbes (2003:283).

Como conseqüência do pacto entre os súditos para criar o Estado, o Poder que emana deste pacto deve ser superior a toda e qualquer outra fonte de Poder, em especial da religião doméstica.

Conseqüentemente, o Estado, ao ser constituído passa a ser a fonte única do Direito e do Poder coativo indispensável para evitar o estado de natureza. Com isso substitui o Direito Natural pelo Direito Civil, negando valor e legitimidade às demais formas de Direito. Hobbes, assim, antecipou a estrutura do Positivismo Jurídico.

Até então, no microcosmo da família, o pater familias reinava absoluto. Entretanto, com o advento do Estado, que passa a desempenhar funções antes adstritas ao âmbito privado com o propósito de garantir a segurança e a sobrevivência de seus súditos, suas funções e poder foram reduzidos.

Logo, da mesma forma que o lar, o Estado deveria ser governado com o propósito de prover para os súditos do soberano, este seria o supremo pater familias - o pai de todos os pais de famílias. 
Rousseau, anos depois de Hobbes, deixou clara a transformação sofrida pelo papel social do pater familias e da economia doméstica ao analisar a Economia Política.

Ele inicia o seu "Discurso sobre a Economia Política" da seguinte maneira, "Economia (...) tendo significado originariamente o sábio e legítimo governo da casa voltado para o bem comum de toda a família. Posteriormente, esse termo teve seu significado estendido ao governo da grande família que é o Estado. Para melhor distinguir as duas concepções, a essa última chama-se economia geral ou política e à primeira economia doméstica ou particular. (....) A respeito da economia doméstica, veja-se PAI DE FAMÍLIA”, Rousseau (1996:21).

Rousseau neste ponto faz referência à entrada de Chevalier de Jaucourt sobre pai de família na “Enciclopédia” organizada por e Diderot e D’Alembert. Porém, na Encyclpédie não existe a citada entrada, mas uma genérica, que também trata do pai de família.

"Une femme, des enfans, autant d'ôtages qu'un homme donne à la fortune. Un pere de famille ne peut être méchant, ni vertueux impunément. Celui qui vit dans le célibat, devient aisément indifférent sur l'avenir qui ne doit point l'intéresser ; mais un pere qui doit se survivre dans sa race, tient à cet avenir par des liens éternels. Aussi remarque-t-on en particulier, que les peres qui ont fait la fortune ou l'élévation de leur famille, aiment plus tendrement leurs enfans; sans doute, parce qu'ils les envisagent sous deux rapports également intéressans, \& comme leurs héritiers, \& comme leurs créatures ; il est beau de se lier ainsi par ses propres bienfaits.”

Para Jaucourt, cabia ao pai de família a gestão do lar com o propósito de elevar a família, o que somente seria possível por meio da gestão prudente dos recursos.

Ainda nesta época, Direito, Economia e Política estavam interligados pela ética e pela moral, possuindo estreitos laços para com estas, e caminhavam juntas há vários séculos. 
Freqüentemente eram abordados nas mesmas obras. Este fato se explica, pois, grande parte dos autores era formada por filósofos e pensadores com grande variedade de objetos de estudos, e que indistintamente abordavam o que conhecemos hoje por Ciências Naturais e Ciências Humanas, transitando com bastante desenvoltura entre as duas.

Neste sentido, Macpherson (1991:176-177) é bastante esclarecedor. "Quando a economia tornou-se um campo de investigação exclusivo, ela ainda estava estreitamente associada à política e à filosofia. Os primeiros economistas descreveram sua matéria como aritmética política ou economia política, e o mais famoso deles, Adam Smith, filósofo moral de profissão, sempre considerou a economia e a política como ramos da filosofia moral”.

Nesta época houve o primeiro ensaio para separá-los para depois caracterizá-las como ciências, na esteira do cientificismo. E o Estado Moderno se beneficiaria desta especialização, especialmente com o desenvolvimento da Economia e, porque não, do Direito também.

“Pode-se dizer, pois, que o Estado Moderno surge de duas vertentes distintas na compreensão do poder político. Uma é a visão jurídica, com base na noção de império. A outra é a visão econômica, com base na idéia de gestão de coisa púbica”, Ferraz Jr. (2007:422).

Com a criação do Estado Moderno, a Economia ganha força e destaque, pois, de acordo com Michel Foucault (2007:288), “foi através do desenvolvimento da ciência do governo que a economia pôde centralizar-se em certo nível de realidade que nós caracterizamos hoje como econômico: foi através do desenvolvimento desta ciência do governo que se pôde isolar os problemas específicos da população; mas também se pode dizer que foi graças à percepção dos problemas específicos da população, graças ao isolamento deste nível de realidade, que chamamos a economia, que o problema do governo pôde enfim ser pensado, sistematizado e calculado fora do quadro jurídico da soberania.” 
Podemos dizer, então, que se o Estado foi criado por um pacto entre os homens no exercício de seu direito, a Economia viabilizou a sua existência e desenvolvimento. Sem esses dois pilares possivelmente não conheceríamos o Estado Moderno.

Um dos grandes desafios enfrentado à época foi administração do Estado pelo supremo pater familias, numa época em que o soberano se confundia com o próprio Estado por ele governado e personificado. Estado este que freqüentemente sofria com gastos desmedidos, cujo financiamento era feito por meio de abuso dos próprios súditos, com confiscos e tributos excessivos e com vaidades que terminavam em longas e onerosas guerras que dizimavam a força de trabalho e os cofres.

Logo, a transposição da administração da casa, para administração do Estado assume papel de relevância, pois "governar um Estado significará portanto estabelecer a economia ao nível geral do Estado, isto é, ter em relação aos habitantes, às riquezas, aos comportamentos individuais e coletivos, uma forma de vigilância, de controle tão atenta quanto a do pai de família”, Foucault (2007:281).

\subsection{Do oikodespótes para o pater familias.}

Na Antiguidade, a família era central às sociedades e possuía posição de destaque na estrutura e no desenvolvimento social. Não seria surpresa encontrar em outras sociedades patriarcais da época, ou até mesmo em períodos anteriores, papel social similar a do pater familias romano.

É o que aponta Fustel de Coulanges (2004:99), segundo ele “os latinos diziam paterfamilias e materfamilias, os gregos oikodespótes e oikodéspoina, os hindus grihapati e grihapatni.”

Para buscar compreender o seu significado e papel social na sociedade da época, toma-se como ponto de partida a análise de léxicos e dicionários. 


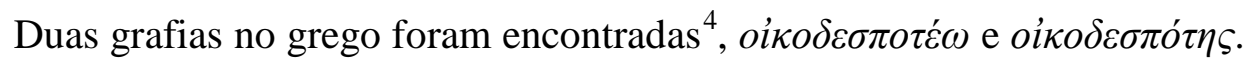
A primeira grafia teria por significado "to be master of the house, to rule the household". A segunda grafia, por seu turno, significaria "the master of the house, the good man of the house”.

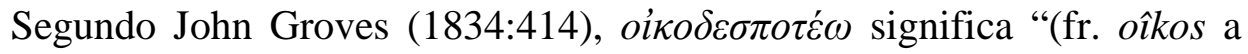
house, and $\delta \varepsilon \sigma \pi o ́ \tau \eta \varsigma$ a master) to manage the house, regulate household affairs; to rule;

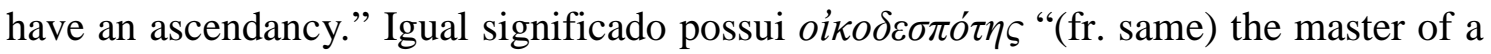
house”, Groves (1834:414).

Vez que oikodespótes é formado pelos vocábulos oîkos e $\delta \varepsilon \sigma \pi o ́ \tau \eta \varsigma$, resta analisar o significado destas duas palavras. Oîkos seria “A house, mansion, dwelling, abode; a house of God, temple; a palace, court; an apartment; a home; a family, household; lineage, descent; property, substance”, Groves (1834:414). Enquanto

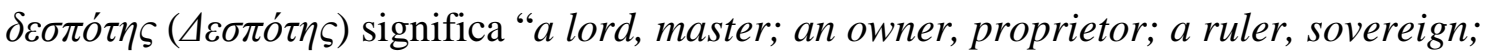
a despot”, Groves (1834:136).

De acordo com Henry George Lidell e Robert Scott (1996:1204),

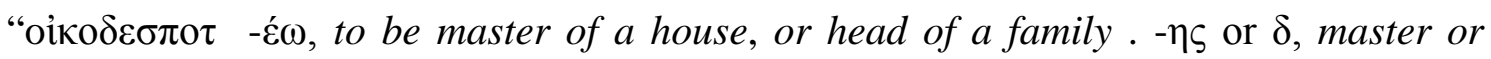
steward of a house. - ıкós, fit for a pére de famille."

Na mesma linha anterior, oîkos significaria "house, not only of built houses, but of any dwelling-place; 2. room, chamber; 3. of public buildings, meetinghouse, hall, dining-hall; 4. cage for birds;5. Astrol., domicile of a planet; II. one's household goods, substance. III.a reigning house”, Lidell e Soctt (1996:1204-1205).

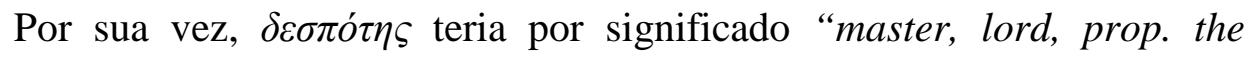
master of the house. 2. Despot, absolute ruler; 3. of the gods; 4. dominant planet; II. generally, master, lord, owner”, Lidell e Soctt (1996:381).

\footnotetext{
4 De acordo com o léxico do grego disponibilizado na Internet pela Universidade de Tufts (http://www.perseus.tufts.edu/hopper/).
} 


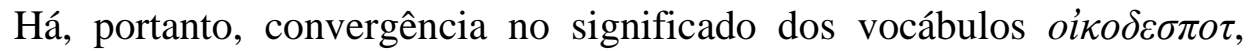

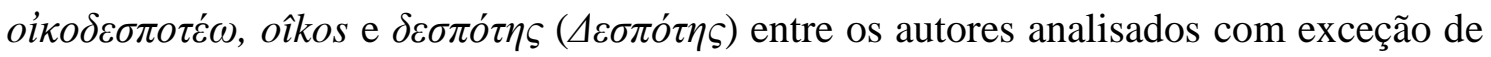

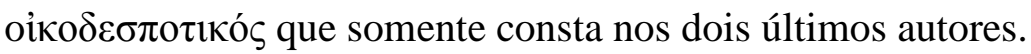

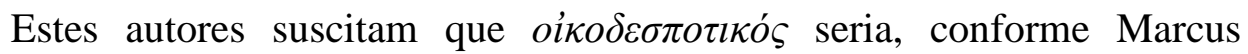
Tulius Cicero, correspondente ao pater familias romano. Veja-se o que diz o romano a este respeito, primeiramente no texto em inglês. "You say you are negotiating through Mustela. He is a very suitable person and very devoted to me since the affair of Pontianus. So get something settled. But what is wanted except an opening for a purchaser? And that could be got through any of the heirs. But I think Mustela will manage that, if you ask him. You will have provided me not only with the very place I want for my purpose, but a place to grow old in besides. For Silius' and Drusus' places don't seem to me quite fit for a paterfamilias. Why, I should have to spend whole days in the country house. So I prefer the others, Otho's first and then Clodia's. If nothing comes of it, then we must play a trick on Drusus or fall back on the place at Tusculum”, Cicero (1961:93).

E, em latim.“Quod per Mustelam agis, habes hominem valde idoneum meique sane studiosum iam inde a Pontiano. Perfice igitur aliquid. Quid autem aliud, nisi ut aditus sit emptori? quod per quemvis heredem potest effici. Sed Mustelam id perfecturum, si rogaris, puto. Mihi vero et locum, quern opto, ad id, quod volumus,

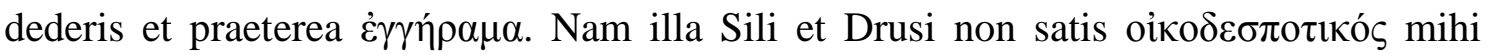
videntur. Quid enim? sedere totos dies in villa? Ista igitur malim, primum Othonis, deinde Clodiae. Si nihil fiet, aut Druso ludus est suggerendus aut utendum Tusculano”, Cicero (1961:92).

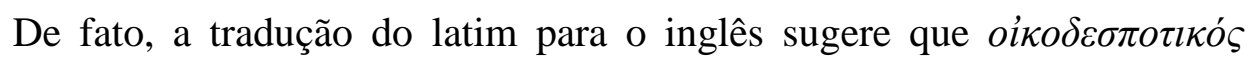
tenha o sentido de pater familias. Ou seja, aparentemente há correspondência entre o significado de pater familias, no latim, e oikodespótes, no grego.

Conforme dito anteriormente, o lar familiar daquela época era gerido com prudência. A casa não significava apenas uma propriedade. Era também um local produtivo, onde os escravos e as mulheres se ocupavam em produzir e atender as 
necessidades materiais daqueles que nela residiam e comercializavam o excedente. Seu principal objetivo era o suprimento dos recursos indispensáveis para vida daqueles que nele residiam, em Roma, os filii familias.

Os poderes do Estado não limitavam os poderes no âmbito privado, os quais eram exercidos pelo oikodespótes e pelo pater familias nos seus respectivos lares. Não seria, portanto, difícil concluir que existia uma bem marcada separação entre o lar (o privado) e a cidade (o público). No primeiro imperava a desigualdade, ao passo que no segundo, a igualdade, contudo a posição na cidade dependia do status ocupado pelo gestor da casa.

O lar de antigamente teve que paulatinamente ceder espaço às cidades, e os chefes responsáveis por essas reuniões de lares, que eram os “pais” de todos aqueles que nelas se encontravam, necessitavam igualmente de poder e autoridade. Isto implicou na redução e relativização dos poderes dos senhores da casa. Processo similar ao do surgimento do Estado Moderno.

O Direito escrito surgiu para regrar a convivência nas cidades, estabelecer padrões de pesos e medidas, regular relações entre os indivíduos e solucionar conflitos, especialmente os relacionados à propriedade, e punir.

Esperava-se a adoção de certa conduta ao tratar de negócios com outros pater familias. Os padrões de conduta deveriam ser superiores àqueles empregados ao lidar com seus próprios negócios. Afinal, o pater familias estava tratando com um igual e isso somente seria possível na cidade.

Assim, em Roma, notadamente, surgiram adjetivos para classificar a conduta do pater famílias ${ }^{5}$ em relação ao Direito. O pater familias idoneus, relacionado à administração do Estado; o diligentissirnus pater familias, no tratamento das coisas; o prudens et diligens pater familias, no tratamento com outros; e o bonus pater familias.

\footnotetext{
${ }^{5}$ A discussão acerca do pater familias pode ser encontrada no artigo de Richard P. Saller, Ob. Cit.
} 
É interessante resaltar que "the gendered language of standards of responsibility has a bearing on discussions of gender stereotypes related to economic behavior and household management. (...) the positive stereotype of responsible estate management was gendered as male already in Republican literature through the phrase bonus or diligens pater familias”, Saller (1999:188).

Deu-se, desta forma, um caráter axiológico, moral, a conduta que seria esperada no tratamento entre iguais.

A possibilidade de se ter condutas bem diferenciadas, e, ao mesmo tempo, antagônicas para o âmbito privado e o âmbito público, as primeiras irrestritas e fundadas na religião e as segundas limitadas pelas leis da cidade, por mais que ainda possuam fundamento religioso, demarcam o império do pater familias.

\subsection{Sobre o (bonus) pater familias propriamente dito.}

É possível identificar duas dimensões na figura do bonus pater famílias.

A primeira dimensão, a dimensão legal, não será abordada no presente trabalho, posto que envolve análise dos textos legais da época e das obras dos jurisconsultos romanos. De certa forma, um processo de arqueologia que requer conhecimentos apropriados, cobrindo desde a filologia à sociologia.

Como seria esperável, a doutrina somente faz uso desta dimensão, e que no Direito Pátrio não está presente nos textos legais, apenas na doutrina. Há, porém, outra dimensão, que no caso do bonus pater familias é mais evidente. Esta dimensão é geralmente deixada de lado: a posição social ocupada pelo indivíduo.

A segunda, a dimensão social, porém, será objeto de estudo. Ela fornecerá os argumentos necessários para concluir que o pater familias dos juristas é um ascendente muito próximo do Homo oeconomicus dos economistas. Esta proximidade pode causar estranheza aos juristas mais tradicionais, acostumados a ligar o Direito à moral, ou a atribuir ao Direito uma dimensão moral. 
Isso porque, possivelmente a primeira impressão que se tem do termo bonus pater familias estaria relacionada com a sua carga valorativa. Por seu turno, tradicionalmente o Homo oeconomicus foi construído como sendo amoral e calcado no auto-interesse.

Porém, os juristas mais tradicionais deixam de lado uma das principais funções do Direito: a de limitar coativamente o auto-interesse individual por meio do estabelecimento de parâmetros de referência aceitáveis para o convívio entre os indivíduos na sociedade. Logo, o próprio Direito teria por função limitar a atuação do Homo oeconomicus.

Assim, ao contrário de rejeitar e suprimir o auto-interesse, o Direito reconhece a sua existência como característica marcante do indivíduo. Uma resposta à condição de amoral e à ausência de limites do Homo oeconomicus dos economistas, somente possível por meio do Direito. Neste sentido, o Homo oeconomicus quando utilizado no âmbito do Direito estaria sob total domínio deste último.

Entender e contextualizar o pater familias não é tarefa das mais fáceis. Mesmo entre os romanistas e pesquisadores da sociedade daquela época ainda existem divergências. Por mais que existem documentos, somente seria possível ter o correto entendimento do pater familias, sua origem e desenvolvimento, se, de alguma forma fosse possível voltar no tempo. E mesmo se isto fosse possível, a sociedade da época seria vista pelas lentes do arcabouço teórico atual, dos usos, costumes e da moral vigentes. Portanto, esse entendimento seria, de certa maneira, incompleto.

Com o passar dos séculos, as sociedades foram se desenvolvendo e aumentando em complexidade, e os indivíduos, por sua vez, passaram a exercer um número cada vez maior de papéis sociais. Alguns destes papéis foram progressivamente surgindo e se diferenciando, outros desaparecendo.

Segundo Ralf Dahrendorf (1991:52), “A diferenciação das posições sociais é uma das poucas características evidentes de desenvolvimento social (o termo não tem a conotação valorativa de «progresso». Processos como por exemplo «separação entre a Igreja e o Estado» (na Revolução Francesa) ou «separação entre a 
esfera familiar e a profissional» (na revolução Industrial) indicam exemplos recorrentes de tais diferenciações, que se fazem sentir em outros setores da sociedade. Sobre os mecanismos que possam explicar essa forma de mudança social muito pouco sabemos.”

Condutas que outrora eram aceitas, passaram a ser condenadas pela moral vigente na sociedade, tendo, o Direito as incorporado e reprimido. Outras vezes, foi o próprio Direito o fundamento de validade para atrocidades que a própria moral condenaria. Pode-se dizer que o processo que deu origem aos papeis sócias teve início na unidade mais básica da estrutura social e precursora das sociedades complexas de hoje em dia: a família.

Mesmo assim, não é possível afirmar que a família de outrora e a atual possuem significado e importância social semelhantes. No caso de Roma, ainda é mais gritante, devido às particularidades da sociedade no período em que o pater familias era o soberano do lar, podendo legislar, julgar e executar suas decisões sem interferência externa, tal era a separação entre o privado e o público.

A posição social do pater familias era uma dentre as diversas ocupadas pelo indivíduo, porém era a mais importante, devido ao processo de formação da sociedade da época. Foi a família quem deu origem à fundação de Roma, e sua população esta constituída por três elementos básicos: a gens, a clientela e a plebe ${ }^{6}$.

De acordo com José Carlos Moreira Alves, não existe uma única teoria para explicar a formação de Roma, mas a Teoria Gentilícia, de Bonfante, seria a teoria mais robusta, porém não isenta de críticas.

Esta teoria defende que "a gens era um agrupamento de famílias com caráter político, situada num território (pagus), tendo chefe (pater ou magister gentis), instituições e costumes próprios, assembléia (concio) e regras de conduta (decreta gentis). Seus membros se denominavam gentiles, e julgavam descender de um antepassado comum, lendário e imemorável, do qual recebiam o nome gentilício, que,

\footnotetext{
${ }^{6}$ Foi identificada posição diversa quanto a formação da sociedade romana. Neste caso, seriam apenas dois, a família e a gens. TELLEGEN-COUPERUS, Olga. A short history of roman law. Nova Iorque: Routledge, 2003, p.p.6-9.
} 
portanto, era comum a todos os gentiles. E era esse nome comum, e não necessariamente o parentesco consangüíneo, que os vinculava. Os gentiles das diversas gentes, quando surgiu o Estado Romano (ciuitas), formaram o patriciado. E na realeza, somente os patrícios gozavam de todos os direitos civis e políticos”, Alves (2008:9-11).

Por seu turno, a clientela "era uma espécie de vassalagem - de existência antiqüíssima - na qual incidiam indivíduos ou famílias que eram reduzidos, ou se sujeitavam espontaneamente, à dependência de uma gens, desta recebendo proteção”, Alves (2008:10).

Por último, a plebe, era constituída pelos plebeus, uma turba não organizada que não integrava a cidade, não tinham pátria e, a princípio, não possuíam direitos políticos nem civis.

Não obstante a constituição inicial da sociedade romana, os poderes do pater familias e a própria família sofreram alterações ao longo da história com a transformação da sociedade.

Novos usos e costumes foram introduzidos, outros esquecidos ou sofreram alterações. Desta forma, não seria possível dizer que a família de antigamente possui o mesmo significado da família de atualmente, apesar de a família continuar a ser base da estrutura social. Especialmente quando comparada com a sua importância no Direito Romano.

\subsection{A importância da religião doméstica e a origem do Direito Privado.}

O papel da religião também foi sendo paulatinamente reduzido. Apesar de nos dias atuais ainda existirem sociedades e comunidades onde a religião tem grande importância para os indivíduos, este papel e importância não podem ser comparados com os do mundo antigo. Isso porque o mundo antigo era comandado pela religião.

O poder e a autoridade familiar eram exercidos pelo patriarca, e tinham seus fundamentos de validade na religião. Essa posição era ocupada por um ser humano do sexo masculino, que possuía as funções de chefe e de sacerdote da família. Era um soberano doméstico e despótico com amplos poderes derivados da religião. 
A ele cabia as funções de congregar, organizar e de controlar a família, mantendo-a unida e produtiva; de administração da casa, incluindo o provimento dos meios necessários para garantir o sustento e a prosperidade do lar; e do exercício do sacerdócio doméstico.

Ele se subordinava, apenas, ao lar familiae pater - uma entidade espiritual que representava o senhor do lar da religião doméstica. Em toda casa existia um altar, que possuía fogo, brasas e cinzas. A obrigação de mantê-lo cabia ao dono da casa, não podendo deixar esse fogo - o fogo sagrado - se extinguir. Ele só se extinguia quando toda a família havia se extinguido, Fustel de Coulanges (2004:8-19).

Apenas o homem, no caso o pater familias, poderia exercer o sacerdócio do lar, e cada lar tinha sua própria religião, com regras, ritos e moral próprios. A religião era transmitida de pai para filho. O pater familias era o depositário das máscaras mortuárias e do sobrenome dos antepassados, estes forneciam personalidade ao pater familias. A única plena no Direito Romano.

Os demais ou eram tratados como coisas (como os escravos) ou partilhavam da personalidade do pater familias, pois não a possuíam inteiramente. Era o único na família que poderia ser ao mesmo tempo livre, cidadão romano e, independente do pátrio poder. Desta forma, somente ele era capaz de contrair direitos e obrigações, Marky (1974:179), de acordo com o Direito Privado da época, TellegenCouperus (2003:6).

O pater familias era dotado de patria potestas. Um conjunto de poderes absolutos e vitalícios que o pater familias detinha sobre os filli famílias, que aos poucos foram sendo diminuídos e abrandados, em especial com a intromissão do Estado no domínio familiar. Essa conduta refletia padrões de zelo, cuidado e diligência que foi aos poucos e com o passar do tempo incorporada ao Direito da época.

Apenas depois do advento do cristianismo que a personalidade tornou-se atributo reconhecido a todo ser humano. Até então, não existia um conceito genérico de pessoa, mas graus de personalidade, (Supiot, 2007:27). 
Os poderes e autoridade do pater familias precisavam ser absolutos, não reconhecendo influência nem sofrendo limitações externas, nem mesmo o Estado podia intervir no seio do lar. Este aspecto, para os padrões atuais, aclara um lado mais sombrio do pater familias. Ele podia dispor sobre a propriedade, inclusive daquela adquirida por seus filhos ${ }^{7}$, a vida e determinar a morte daqueles que habitavam o seu $\operatorname{lar}^{8}$, sem prestar contas.

Com relação à propriedade, foi a religião presente no lar quem primeiro garantiu o direito de propriedade, sendo este direito protegido pelas divindades domésticas, Fustel de Coulanges (2004:64). Desta mesma religião, ou seja, do lar e do ambiente familiar, que nasceu o Direito, mais exatamente o Direito Privado.

Apesar de seu fundamento último de validade ser a religião, não se trata de um Direito revelado por Deus, mas de uma construção humana como a própria religião que o legitimava.

Neste sentido o ensinamento de Fustel de Coulanges é esclarecedor. “A família não recebeu da cidade as suas leis. Se a cidade tivesse estabelecido o direito privado é provável que instituísse normas diferentes (...). O direito privado existiu antes da cidade. Quando a cidade principiou a escrever suas leis, achou esse direito já estabelecido, vivendo enraizado nos costumes, fortalecido pelo unânime consenso dos povos. O direito antigo não é obra do legislador; o direito, pelo contrário, impôs-se ao legislador. Teve sua origem na família”, Fustel de Coulanges (2004:85).

Esta construção conflita com o que o mundo moderno está acostumado, pois atualmente não há participação direta da família, sendo os usos, costumes e leis impostas igualmente aos seus membros quando nascem. Trata-se de uma herança social, juntamente com a cultura e a língua, que exercem importante papel na formação e manutenção da personalidade individual.

\footnotetext{
${ }^{7}$ Segundo Marky (1974, p.180) Justiniano teria modificado essa prática, pois a qualificou de desumana.

${ }^{8}$ De acordo com Marky (1974, p179) a prática de matar o filho ou abandoná-lo foi proibida por Valentiano I e Valêncio.
} 
A função do Direito Privado nascente era bem definida e refletia as próprias necessidades familiares e as funções do pater familias. Os direitos patrimoniais estavam nele centralizados, sendo ele a única pessoa com personalidade; somente ele podia dispor sobre ela, mesmo se adquirida pelos filii familias. Esta capacidade de contrair direitos e obrigações com relação a direitos patrimoniais se chamava commercium, Correia e Sciascia (196:35)

Tem-se, assim, de acordo com José Reinaldo de Lima Lopes (2000:59), que "o direito privado, quando bem analisado, é um sistema de regras pelo qual se mantém unida a família como unidade produtiva”.

Corroborando com esta opinião, Saller (1999:184) aponta a principal autoridade decorrente do poder do pater familias. A capacidade de ter propriedade (dominium) e exercê-la, dotando-a de função marcantemente econômica.

Para o citado autor, a paternidade não era o aspecto essencial do pater familias, pois poderia ter propriedade sobre escravos, casas, terras e utensílios para fazer do lar uma unidade produtiva. Ele continua, neste aspecto, a mulher romana - a matter familias - se igualava ao pater familias. Especialmente a mulher sui iuris pertencente aos estratos sociais mais elevados da sociedade ${ }^{9}$.

Ser um pater familias não significava ter idade suficiente (como ser maior de idade nos dias atuais ou emancipado); possuir laços sanguíneos com uma determinada família; ou, ainda, possuir descendentes. Isso porque o poder do pater familias poderia ter origem de diferentes formas, sendo elas pela morte do pater familias, a adrogatio, a adoptio e a conventio in manum, Correia e Sciascia (1961:100101).

\subsection{O pater familias no Direito Pátrio.}

Não raro os cursos de Direito Civil, os trabalhos sobre direito das obrigações; as obras sobre responsabilidade civil; e os tratados de direito privado fazem

\footnotetext{
${ }^{9}$ Neste ponto Fustel de Coulanges e Saller divergem, conforme pode ser visto em Fustel de Coulanges (2004, p.p 86-87).
} 
menção ao pater familias do Direito Romano ${ }^{10}$. Geralmente o adjetivam como bonus pater familias - o bom pai de família.

De certa forma poderia ser dito que o bonus pater familias sofreu processo similar conforme ao que correu com a palavra Politicus ${ }^{11}$. Para isto, ambos deveriam ter sofrido alterações de significado e uso, mas mantendo estáveis seus núcleos.

Porém, não foi o que ocorreu com o bonus pater familias, pois não há estabilidade de referência para o padrão utilizado na determinação da culpa in abstrato, e foi deixada à margem a dimensão patrimonial.

Para melhor evidenciar a menção ao bonus pater familias feita pelos civilistas brasileiros mais tradicionais, veja-se, por exemplo, o que diz Clóvis Bevilaqua, em pelo menos duas passagens ao comentar o Código Civil de 1916.

Ao analisar as obrigações do comodatário (art. 1251), observa, "Deve o comodatário zelar a coisa emprestada como se sua própria fôra, diz o Código, para significar o cuidado extremo, e não para sujeitar a coisa alheia às vicissitudes de possíveis desleixos de perdulários. Aliás o comodatário, como se vê do art. 1.253, deve ainda maior solicitude ao objeto do comodato do que às suas próprias coisas. In rebus commodatis talis diligentia praestanda est, qualem quisque diligentíssimus pater familias, suis rebus adhibet (D. 13, 6, fr. 18. pr.)”, Bevilaqua (1980, t.2:356).

Com relação às obrigações do depositário ele faz outra observação, desta vez mencionando o pai de família. "Segundo a distincção classica, a culpa é in abstracto, quando se toma por typo de comparação, um diligente pae de família, e in concreto, quando se tem em vista o próprio indivíduo (obs. 1 ao art. 1057); mas o Código Civil não se ateve a estas e outras distincções, para tirar dellas consequencias jurídicas. Limita-se a determinar a culpa, segundo as circunstancias, em que se acha a pessoa”, Bevilaqua (1980, t.2:379).

\footnotetext{
${ }^{10}$ Ver, por exemplo, José Carlos Moreira Alves, Direito Romano, p.621.

${ }^{11}$ O processo de evolução do termo Politicus pode ser mais bem analisado em Rubinstein, 1990.
} 
Outro autor de reconhecida importância, Manuel Inácio de Carvalho de Mendonça, da mesma forma, faz menção ao pai de família ao analisar a culpa. "Para qualificá-la de leve, toma-se aí por tipo a diligência que emprega um pai de família cuidadoso”, Carvalho de Mendonça (1956, t.2:18).

Nesta mesma toada, para Orlando Gomes (2006:109), “No adimplemento da obrigação, o devedor está adstrito a comportar-se como bom pai de família, isto é, com a diligência usual do homem que cuida de seus interesses com exação.”

Algumas linhas depois o citado autor faz nova referência. "No ato de executar a prestação o devedor tem de agir igualmente com a diligência do bom pai de família, evitando pagar a outrem que não o credor ou a pessoa que não o represente ou não tenha qualidade para receber”, Gomes (2006:109).

E, ainda, mais adiante, uma vez mais. "Como, entretanto, o devedor inadimplente responde por perdas e danos, a doutrina tradicional funda sua responsabilidade no comportamento que tenha, referindo-se ao tipo abstrato do bom pai de família, eis que deve conduzir-se com diligência normal”, Gomes (2006:169).

As obras jurídicas estão repletas de referências como essas. Todavia, dificilmente é encontrado o seu conceito ou descrição, como se a própria invocação do termo fosse suficiente para despertar no leitor todo o seu significado na linguagem jurídica, tendo formação ou não na área. Algo como um “dever-saber”.

Parte da influência do Direito Romano no Direito Pátrio advém do Direito Germânico, outra, possivelmente, pelo próprio processo de formação da doutrina pelos juristas brasileiros, sobretudo a partir da edição do Código Civil de 1916.

Apoiando-se em José de Aguiar Dias, nesse sentindo é possível vislumbrar um dos possíveis caminhos que o bonus pater familias poderia ter trilhado até o Direito Pátrio.

Segundo o citado autor, o sistema alemão foi o que mais fielmente permaneceu ao Direito Justinianeu, devido à expansão e influência do Direito Romano 
na Alemanha durante o séc. XIX. Neste sistema se desenvolveu a tendência subjetivista que sustenta a aplicação individual da culpa no Direito Penal, e, por analogia, foi trazida para o Direito Civil, Dias (2006:61).

"Foi o legislador alemão que, embora mantendo a noção de culpa determinada pelo grau de diligência do bonus pater familias, não somente nas relações contratuais, mas também nos casos da chamada responsabilidade delitual em lugar de procurar dissimular sob a capa da culpa pelo emprego de presunções (...).” Dias (2006:65). “a doutrina alemã, para proporcionar medida estável da culpa, se serve do critério Justiniano do bonus paterfamilias; a literatura e a jurisprudência imputam ao agente as conseqüências de seu ato, mesmo que nas aos possa prever (...)”, Dias (2006:138)

Com isso, naquele sistema, o grau de diligência do bonus pater familias passou a ser adotado como o padrão para a verificação da culpa in abstrato, objetivando (ou desejando) proporcionar uma medida estável de culpa.

Ao contrário do que existia em Roma, primeiramente na época da República e posteriormente na época do Império, não há qualquer menção do legislador pátrio ao bonus pater familias.

Mesmo sendo um recurso discursivo, não possuindo estabilidade de conteúdo e de limites, falta-lhe, ainda, estabilidade de nomenclatura. Seria minimamente desejável que se convencionasse qual nomenclatura seria utilizada para não prejudicar a estabilidade do conceito nem dificultar o entendimento decorrente de seu uso.

\subsection{A incerteza terminológica: como se chama o pater familias no Direito Pátrio?}

Não é difícil encontrar exemplos na doutrina que aclaram essa ausência de convenção, pois outros termos também são encontrados nas obras dos juristas brasileiros. Algumas de origem menos evidente, mas com uso claramente influenciado pelo bonus pater familias de outrora. 
Em alguns casos o bonus pater familias seria o homem médio, o homem padrão, Wald (2001:571) ${ }^{12}$; e, em outros, seria o homem diligente, o homem diligente e probo, o homem prudente e diligente ${ }^{13}$, Dias (2006:142); o homem razoável ou o homem avisado. E, conforme dito, em pelo menos um caso o bonus pater familias teria por sinônimo o Homo oeconomicus.

Existe, portanto, incerteza terminológica entre os juristas - os próprios responsáveis pela produção discursiva e desenvolvimento da linguagem jurídica. Afinal, qual seria a denominação apropriada? E mais, seria o bonus pater familias o Homo oeconomicus? É possível argumentar neste sentido.

O homem médio seria, por assim dizer, o equivalente do bonus pater familias no Direito Penal, onde surge com mais freqüência, não obstante ser, também, mencionado no Direito Civil, Dias (2006:72) ${ }^{14}$.

Contudo, nem de longe o homem médio poderia ser considerado sinônimo do bonus pater familias. Além disto, os civilistas cometeram o equívoco de transpor um possível padrão médio de pater familias para um padrão médio representativo do cidadão comum, deixando de lado as particularidades do primeiro e a sua dimensão patrimonial, conforme dito.

Da mesma forma que o legislador não faz menção ao bonus pater familias, também não o faz dos demais termos. Porém, ao contrário do afirmado sobre o bonus pater familias, as origens destes termos no Direito Pátrio são menos claras, sendo tarefa nada simples identificar como e quando foram incorporados pela linguagem

\footnotetext{
12 “A apreciação da culpa pode ser decorrente da conduta do agente no caso específico com a conduta que geralmente costuma ter (critério concreto), ou com a do bom pai de família considerando como homem padrão (critério abstrato). (...). Ao contrário, a conduta do motorista deve ser o do bom pater familias (art.159)”.

13 “Ora, ao homem prudente e diligente, ao bom pai de família, admite-se que erre, porque é condição do homem a falibilidade. Aquilo que um homem prudente faria, se colocando nas condições do imputado, pode, muitas vezes, ser o ato que o coloque em culpa, digamos, leve.”

14 “Que se pode censurar, por exemplo, ao homem que, por uma fatalidade da natureza, não é tão destro, tão prudente, de raciocínio tão pronto, de vista e ouvidos tão bons como o average man?” Ainda, na nota 246 da p. 145, "O homem prudente, average man, o bom pai de família e outros que tais só o são enquanto não pratiquem um ato de culpa mínima, que desfaz todo o seu passado”.
} 
jurídica e pelo discurso jurídico. Desses termos, o de origem menos obscura, conforme poderá ser visto, é o homem médio.

Seria de se esperar que, por conta das referências feitas ao Direito Romano, a doutrina tradicional, especialmente a brasileira, abordasse com mais detalhe o conceito de bonus pater familias. Contudo, esta pressuposição não está correta.

José Carlos Moreira Alves (2008:406), ao debater os graus de culpa no inadimplemento das obrigações diz o seguinte, “culpa leuis: que pode ser in abstracto (quando o devedor não se utiliza da diligência do bonus pater familias - tipo médio de pater familias) ou in concreto (quando para se apurar se o devedor agiu com culpa em sentido restrito se confronta sua atuação, não com um tipo abstrato como o bonus pater familias, mas, sim, com a atitude que o próprio devedor toma com relação às suas coisas e aos seus interesses.”

Esta culpa seria, juntamente com a culpa lata, as únicas encontradas nos textos romanos, sendo esperado, e até mesmo estipulado, que o devedor, responsável pelo adimplemento da obrigação, se comportasse (ou devesse se comportar) como o bonus pater familias.

Thomas Marky (1974:134), ao tratar da culpa, tem a seguinte posição: “O dolo não tem graduações, mas a culpa tem: distingue-se a culpa levis da culpa lata. A primeira é a negligência leve, em comparação à diligência e cuidado do homem médio (bonus paterfamilias). A segunda é a negligência exorbitante; não agir com o cuidado que todos têm (non intelligere, quod omnes intelligunt).”

Como é possível notar, neste trecho o autor associa o bonus paterfamilias ao homem médio. Mais adiante ele continua, “A culpa levis é referida normalmente a uma medida objetiva: ao cuidado do bonus paterfamilias. [...] A culpa levis, cuja medida tem como referência a diligência do bonus paterfamilias, é chamada de culpa levis in abstracto; e a culpa que se reporta à conduta costumeira do próprio devedor, é a denominada culpa levis in concreto. Se a impossibilidade da prestação não podia ser evitada nem pela diligência ou cuidado de um bonus paterfamilias, o acontecimento havido é considerado casus, acaso, caso fortuito”, Marky (1974:134). 
Os autores Alexnadre Correia e Gaetano Sciascia (1961:174) tratam de forma similar a culpa. “Culpa levis consiste em não observar, no cumprimento da obrigação, o cuidado que teria um homem médio e normal, o tipo abstrato do bonus paterfamilias. Êsse grau de culpa é chamado também culpa in abstrato, em contraposição à culpa in concreto a qual é medida pelo cuidado que, na espécie, o indivíduo costuma aplicar às suas coisas (diligentia quam suis rebus).”

O último dos autores consultados, Ebert Chamoun (1950:109), ao analisar os atos ilícitos, explicita os tipos de culpa da seguinte forma. "O direito justiniâneo classifica a culpa, segundo a gravidade, em culpa lata e culpa laevis, e conforme a pessoa, em culpa in asbtracto e culpa in concreto. A culpa lata consiste em não usar a diligência que até o homem descuidado costuma ter; a culpa laevis consiste em não usa a diligência que só tem o diligens paterfamilias, a culpa in concreto ocorre quando êsse comportamento nem se nivela com a diligência que a pessoa costuma ter com os próprios negócios.”

Conforme pode ser visto, pouco se agrega ao consultar as doutrinas mais tradicionais de Direito Romano. Essas doutrinas se limitam a definir a culpa e a conduta esperada do pater familias. Por sua vez, as doutrinas de Direito Civil se aliam integralmente ao tratamento dado à conduta culposa pelas doutrinas de Direito Romano.

Ao fazer isto, os doutrinadores acabam por incorrer no mesmo erro, pois não fornecem o conteúdo e os limites do conceito, e se equivocam ao transpor um possível tipo médio de pater familias para o tipo médio do cidadão comum.

Depois de verificar como o Direito Romano e o Direito Civil tratam a conduta culposa na expectativa de encontrar o conceito do bonus pater familias, ou pelo menos algum tipo de conteúdo e limites, ainda que tênues, o próximo passo é buscá-los nos dicionários e enciclopédias. 
O Oxford Latin Dictionary fornece nada menos do que oito usos para o vocábulo pater. Uma delas diz respeito à posição dentro da família. “4 a ter familias (ae), The head of a family, a householder." 15

Para se compreender o significado de pater familias é necessário entender o significado do vocábulo família. De acordo com o mesmo dicionário, famlia $^{16}$ possuía seis usos distintos e que podem ser agrupados da seguinte forma.

Dois usos dizem respeito às relações de parentesco. “1 All persons subject to the control of one man, whether relations, freedmen, or slaves, a household. $\mathbf{b}$ PATER, MATER, FILIVUS, FILIA as or ae, the master, mistress, son or daughter of a household.(...) 4 A body of person closely associated by blood or affinity, family.”

Três usos dizem respeito ao patrimônio, sendo importante notar que os escravos naquela época eram considerados coisas, podendo ser adquiridos e alienados, e, por sua vez, integravam o patrimônio da família.

Um dos usos, o uso legal (leg.), salienta que na linguagem jurídica significava, em termos abrangentes, a propriedade onde se morava. " 2 The slaves of a household, servants. 3 A group of servants domiciled in one place; esp. a gang used for a particular purpose. b one's personal servants, retinue. (...) 6 (leg.) Estate (consisting of the household and household property); (sts. dist. from pecunia, and possibly restricted to res mancipi).”

Na obra A Latin Dictionary, de Lewis e Short, família significa "II. Transf. A. With the idea of house predominating. 1. In gen., a house and all belonging to it, a family, estate, family property, fortune.”

A origem do bonus pater familias é clara. Também é clara a origem do homem médio, ao contrário das origens das demais terminologias, que não são tão evidentes.

\footnotetext{
${ }^{15}$ Oxford Latin Dictionary. Oxford: Clarendon Press, 1968, p.1308.

${ }^{16}$ Oxford Latin Dictionary. Oxford: Clarendon Press, 1968, p.p. 674-675.
} 
O pater familias era a denominação romana para uma posição social que de fato teve existência concreta numa sociedade. Seu significado somente pode ser entendido se remetido ao contexto do processo de desenvolvimento daquela sociedade.

Entretanto, por mais que certos aspectos e características tenham se exaurido na atualidade das sociedades ocidentais, alguns traços herdados dessa figura antiga ainda podem ser identificados, mas que não justificam a imortalidade do bonus pater familias no Direito Pátrio.

Ao contrário, o homem-médio (bem como os demais: homem diligente, homem diligente e probo, homem prudente e diligente, homem razoável e homem avisado) é um tipo abstrato que não pode ser verificado em nenhuma sociedade.

Na história da Estatística é encontrada uma figura com a mesma terminologia daquela encontrada no Direito: L'Homme moyen ou homem-médio na língua materna.

O conceito de homem-médio foi criado por Lambert Adolphe Jaques Quetelet no bojo de sua Física Social e como critério de comparação para permitir a análise de diversos dados estatísticos coletados da sociedade.

Segundo Stigler (1986:170), “The average man was a fictional being in his creator's eye, but such was his appeal that he underwent a transformation, like Pinocchio or Pygmalion's statue, so that he still lives in headlines of our daily papers. Actually, despite his exclusive use of the singular masculine noun, there was in Quetelet's work not just one average man, but a whole species of average men and average women. The concept initially came about as Quetelet sought to summarize anthropometric data for the purpose of investigating the relationships between and differences among groups of people.”

A intenção de Quetelet era estabelecer os fundamentos de sua Física Social. Deste modo permitiria uma análise criteriosa dos dados da sociedade e, com isto, descobrir as leis que nela incidiriam e determinariam o comportamento e as ações humanas. 
Assim, partindo da posição social ocupada na sociedade, analisou dados relacionados com as características e qualidades, através de um tripé: as físicas, as intelectuais e, as que de alguma forma indicassem, as morais.

É inevitável dizer que os dados por ele coletados e utilizados eram objetivos e esta objetividade permitiria a matematização das ciências sociais.

Pelo trabalho de Quetelet, é possível concluir que existiriam diversos homens-médios, de acordo com idade, sexo, raça, país, escolaridade, posição social e assim por diante. Inclusive com combinações entre as diversas características encontradas ou passíveis de serem encontradas na sociedade, as quais poderiam variar no tempo e no espaço, e forneceriam ao cientista a flexibilidade necessária para seus estudos.

Invariavelmente estes estudos buscavam a determinação das relações de causalidade existentes. O número de nascimento em determinada data comparado com o número de casamentos em época anterior; as características físicas dos condenados por determinado crime; as taxas de suicídio; as taxas de condenação e assim por diante. Estas relações de causalidade indicariam, quando persistentes e estáveis, uma tendência social, da qual poderiam ser extraídas leis.

O trabalho de Quetelet foi bastante influente em sua época a partir de sua publicação em 1835. A Sociologia, a Ciência Política bem como as demais ciências ditas morais naquela época, dele se aproveitaram de alguma forma. Quer pelos recursos retórico-argumentativos que dele obtiveram; quer como subsídios para construir seus próprios fundamentos centrados num indivíduo ficcional.

No século XIX, durante o período em que se desenvolvia o seu padrão de indivíduo, a própria Economia foi influenciada pelo trabalho de Quetelet.

Exemplo disto é a menção feita por Leon Walras (1989:170), “Nous renverrons ceux de nos lecteurs qui voudraient être fixés sur cette question à la Physique sociale, à l'Anthropométrie de Quételet que reproduit aussi la Bibliothèque de l'économiste. Par le parti que la statistique a déjà tire des procédés mathématiques, ils 
jugeront de celui qu'elle en tirerait encore si elle était guidée dans cette voie par l'économie politique.”.

Tal como em Walras, em Jevons, na obra publicada em 1877 é possível encontrar várias referências explícitas à obra de Quetelet. Eis algumas delas.

"This theory of comparative frequency of divergence from an average, was first adequately noticed by Quetelet, and has lately been employed in a very interesting and bold manner by Mr. Francis Galton, in his remarkable work on Hereditary Genius", Jevons (1913:188).

"Quetelet also tested the theory in a rather more complete manner, by placing 20 black and 20 white balls in an urn and drawing a ball out time after time in an indifferent manner, each ball being replaced before a drawing was made”, Jevons (1877:208).

“To ensure all possible accuracy each reversal ought to be combined with each other reversal, so that the needle will be observed in eight different positions by sixteen readings, the mean of the whole of which will give the required inclination free from all eliminable errors”, Jevons (1877:356).

"Roger Cotes, the editor of the Principia, appears to have had some insight into the value of the mean; .but profound mathematicians such as De Moivre, Daniel Bcrnoulli, Laplace, Lagrange, Gauss, Quetelet, De Morgan, Airy, Leslie Ellis, Boole, G1aisher, and others, have hardly exhausted the subject”, Jevons (1877:359).

A obra de Jevons possui, ainda, algumas outras passagens fazendo menção à Quetelet. É inegável que o autor inglês conhecia a obra dele e foi por ela influenciado. Karl Marx, Émile Durkheim, foram alguns outros autores que tiveram acesso as obras e de alguma forma foram influenciados por Quetelet.

Da mesma forma que influenciou a Economia, a influência do trabalho de Quetelet pelo uso de seu homem-médio no Direito é ainda mais gritante. Ele serviria para determinar a propensão ao suicídio e ao crime, ou a probabilidade de o indivíduo 
cometê-los de acordo com o clima, estação do ano, idade, sexo e posição social, além de levar em conta aspectos morais e psicológicos.

Cesare Lombroso e Quetelet eram contemporâneos, e o primeiro publicou sua primeira obra sobre criminologia positiva, o "Homem Delinqüente" (1876), anos mais tarde que Quetelet, publicou sua obra.

Veja-se algumas passagens na obra de Quetelet, primeiramente com relação ao suicídio e, depois, relacionada com a propensão ao crime e, por último, ao crime propriamente dito.

"Suicides present, in both sexes, a very remarkable contrariety, according to the results furnished by tables. Thus, the month of April, attended with the greatest number of suicides among men, is only so in the fifth degree among women; with the latter, the month of August occupies the same rank as April does for men”, Quetelet $(1842: 82)$.

“There is still another important distinction to be made; namely, that two individuals may have the same propensity to crime, without being equally criminal, if one, for example, were inclined to theft, and the other to assassination”, Quetelet (1842:82).

"Society includes within itself the germs of all the crimes committed, and at the same time the necessary facilities for their development. It is the social state, in some measure, which prepares these crimes, and the criminal is merely the instrument to execute them. Every social state supposes, then, a certain number and a certain order of crimes, these being merely the necessary consequences of its organisation”, Quetelet (1842:6).

Não são poucos os trabalhos sobre a influência da obra de Quetelet, mas dois chamam a atenção. O primeiro, centrado na metodologia econômica, de Bert Mosselmans, e, o segundo, no Direito, especialmente no Direito Penal, por Piers Berine. 
Tal a influência de Quetelet na época, não seria de todo inaceitável inferir que o homem-médio do Direito teve origem no homem-médio da Estatística, este encontrado nas obras sobre criminologia e sociologia na época.

Em alguma época, ainda incerta, foi tomado emprestado pelos juristas pátrios com o propósito de incorporar determinadas características e influências sócioculturais de uma dada época e de certo lugar.

Mesmo considerando-se as diferentes origens é possível notar que nos dias atuais essas duas figuras - o homem-médio e o bonus pater familias - possuem a mesma função quando utilizadas pelo Direito: estabelecer o padrão de conduta que seria esperado em determinada situação para, assim, depois de subsumir ao texto legal, concluir se há culpa imputável ao indivíduo.

Portanto, fazer referência ao homem médio, ao bonus pater familias ou a qualquer outra nomenclatura apresentada acima invocaria a mesma função e finalidade, o que, numa análise superficial, tornaria indiferente o uso de uma ou de outra figura, levando a confusão terminológica encontrada na doutrina.

\subsection{O Homo oeconomicus historicamente considerado.}

Invariavelmente críticas são direcionadas ao pretenso irrealismo dos pressupostos utilizados pela Economia. Geralmente, quando não são decorrentes de conflitos ideológicos, têm por objetivo trazer à luz a distância que existiria entre os seres humanos e a representação destes. Representação esta que serve como padrão de indivíduo para avaliar situações em que se defronta com um problema de alocação de recursos e deve decidir entre as alternativas disponíveis, qual deveria escolher.

Aparentemente, a distância seria grande o suficiente para incomodar acadêmicos e proeminentes pesquisadores não apenas da Economia, mas também de outras Ciências Humanas. Os próprios juristas direcionam suas armas para certos pressupostos e conceitos da Economia, entre eles o Homo oeconomicus.

A defesa pela utilização do Homo oeconomicus no Direito seria alvo das mesmas críticas, ainda mais se for considerada a visão tradicional presente no Direito de 
que o cálculo, qualquer que seja ele, é dificultado por conta do excesso de subjetividade inerente à própria disciplina.

Mas será que essa distância, por maior que seja, é relevante para o papel do Homo oeconomicus na Economia ou no Direito? Acredita-se que não. Isso porque as críticas buscam aproximar da realidade um ser fictício, que, devido à sua própria natureza - uma ficção metodológica -, torna irrelevante o questionamento acerca de se os seus pressupostos são subumanos, humanos ou super-humanos.

Os motivos que levam os críticos a acreditar ser indispensável humanizar o Homo oeconomicus não são poucos, e teriam objetivos nobres: aproximar a Economia da realidade e, com isso, evoluí-la. Mas será possível humanizá-lo de modo a reduzir a pretensa distância? A tentativa, por mais que paulatinamente venha se tornando cada vez mais completa e próxima, sempre será incompleta e guardará alguma distância da realidade.

Portanto, a resposta é negativa. Entende-se que não há como humanizar um ser fictício, nem ao menos aproximá-lo do seu correspondente no mundo real. Não é porque o Pato Donald fala, anda sobre duas pernas, se veste, e possui algumas outras características inspiradas nos seres humanos, que o personagem da Disney pode ser considerado um Homo sapiens.

O que se pretende com a utilização do Homo oeconomicus no Direito é o caminho inverso advogado por estes críticos, ou seja, reduzir o excesso de subjetividade do Direito por meio do estabelecimento de critérios mais objetivos quanto ao indivíduo. Utilizando-se a metáfora do Pato Donald, seria equivalente a aproximá-lo dos patos.

Mas, primeiro, um pouco de história do termo Homo oeconomicus.

O termo latino surgiu com Maffeo Pantaleoni e posteriormente foi introduzido na obra de uma pessoa de seu relacionamento e com a qual freqüentemente se correspondia, Vilfredo Pareto. 
Segundo Pantaleoni (1889:11), "È facile intendere come siasi venuto a considerare quale caratteristica specifica dell'homo oeconomicus la soddisfazione piú completa dei suoi bisogni al costo minimo possible, inquantoché um problema economico, in senso lato, si presenta ounque trattasi di conseguire un risultato determinato com mezzi relativamente minimi, ouvero, viceversa, un resultato quasiasi massimo com mezzi dati.”

Depois, em 1909, na obra de Pareto (2007:13-15), na qual o autor menciona a influência da obra de Pantaleoni no seu trabalho,"The new school considers a homo oeconomicus that is a perfect hedonist, and studies the Political Economy of this abstract being. This method is logically irreprehensible, provided one does not forget that every time we revert to the real world, we have to show that the laws we have found in the case of the abstract men we studied are valid in it. Pure Political Economy is somewhat similar to theoretical mechanics. The latter defines the abstract entity it calls material point, and then the other entity that goes by the name of rigid system, or solid body; these definitions are enough to warn us that the conclusions of that science will apply to a natural phenomenon only to the extent that the quality studied by theoretical mechanics is paramount in it. As we progressively want to consider other properties of natural bodies, we are forced to create new abstractions. The perfect elastic body has no more real existence than the perfect rigid body. In nature, there are some bodies that are almost isotropic, but none that is perfectly so. (...) The second remark is that it is not enough to give homo oeconomicus the quality of being a perfect hedonist, but it is also necessary to decide what qualities of foresight, reasonableness, etc. are to be granted to him. We shall see that he is implicitly supposed to be endowed with such qualities to a certain extent. And we do not think this is right, since postulates must always be stated in an explicit way.”

Conforme dito, Schumpeter considera o L'Economo Prudente, mesmo que ainda influenciado pela tradição aristotélica, como seu precursor. Porém, de certo modo podemos dizer que as raízes do Homo oeconomicus remontam a Galileu, Hobbes, Descartes, Julien Offray De La Mettrie, Quetelet, e John Stuart Mill, mas que somente foram consolidadas por Frigerio e culminaram em Pantaleoni. 
Galileu introduziu os experimentos mentais na Física, enquanto Descartes colocou o método no centro da ciência com o propósito de analisar problemas complexos, e separou a mente do corpo - a razão das emoções - dando origem ao que se convencionou chamar de dualismo cartesiano.

Hobbes, tal como Galileu e Descartes, empregou o método matemático, mais especificamente a geometria euclidiana, para solucionar problemas. Tanto Hobbes quanto Descartes fizeram uso do método para conciliar recursos escassos com recursos aparentemente ilimitados.

Se, por um lado, Descartes o fez como uma forma de abstrair as emoções da racionalidade, Hobbes, por outro, tinha a intenção de retirar o homem do estado de natureza e constituir o Estado (um ser artificial, o machina machinarum, cuja função é defender e proteger os homens).

O homem decidiria racionalmente por manter a sua vida e as partes do seu corpo em troca de sua liberdade e paz. Tão logo saísse do estado de natureza, o homem hobbesiano praticaria o comércio.

A argumentação hobbesiana parte da construção de objetos ficcionais, de situações irreais, e do individualismo metodológico criado por ele (mas não expressamente formalizado) para extrair o homem de influências sociais, reduzindo-o a propensões de comportamento.

A concepção utilizada por Hobbes lembra, em certos aspectos, o Homo oeconomicus que foi construído a partir do século XIX. Racional e interessado na sua auto-preservação, isolado socialmente, e capaz de calcular - faculdade que Hobbes denominou de computação. É de se notar, também, que Hobbes antes de Jeremy Bentham já via o homem como um ser utilitarista.

Hobbes lançou a semente do que no século seguinte De La Mettrie denominou de L’homme machine (o homem-máquina). Para De La Mettrie, o homem seria uma máquina deveras complexa para ser definida e descrita a priori, apenas posteriormente isso seria possível e de forma unicamente objetiva. 
Assim, o homem e suas ações, tal como os animais e demais seres, coisas e eventos do mundo físico, seriam vistos puramente como objetos, não tendo espaço para considerações subjetivas ou morais acerca de seu comportamento. O homem passa a ser visto como matéria e pode ser explicado da mesma forma que os fenômenos físicos.

O processo de “coisificação" do homem também teve seu impulso na Estatística, conforme apresentado anteriormente. A tradição mecanicista e racionalista iniciada pelos geômetras Galileu, Descartes e Hobbes, continuada por De La Mettrie e Quetelet teve outros adeptos, pois freqüentemente inspiravam-se nos avanços da Física para desenvolver suas teorias.

Mill, tal como Hobbes, reduziu o homem a um ser cujo desejo seria possuir riqueza e capaz de julgar a eficácia comparativa dos meios para obter o fim desejado (a riqueza). Ele se utilizou de uma abstração ao isolar os motivos que interessavam à sua análise e para a definição do objeto da Economia - os motivos econômicos que levariam a ação humana - com o propósito de transformá-la em ciência autônoma.

Mill, da mesma forma que Bentham antes dele, procurou formular princípios (ou leis gerais) explicativos de fenômenos, de forma similar à Física, mas que seriam utilizados pela Economia. E para isso necessitava de elementos observáveis no mundo real.

Pantaleoni e Pareto seguiram a mesma tradição. Ambos fizeram abstrações e Pareto, mais precisamente, realizou comparações com o que ele chamou de mecânica racional, bem como com a Física e a Química.

Na sua argumentação o comportamento econômico, tal como o enxofre e o oxigênio, não seria encontrado de forma pura no ambiente. Enquanto o comportamento econômico seria influenciado pela convivência do homem em sociedade; na natureza os elementos químicos estariam combinados com outros elementos e impurezas. A pureza só existiria se fosse produzida pelo intelecto humano. 
Foram essas mesmas simplificações e abstrações que levariam à aproximação da Economia com a Matemática.

Pelo resumo apresentado por Gary Becker com relação às definições do escopo da Economia, é fácil concluir que a Economia envolve, sobretudo, a decisão. "Let us turn for guidance first to the definitions of different fields. At least three conflicting definitions of economics are still common. Economics is said to be the study of (1) the allocation of material goods to satisfy material wants, (2) the market sector, and (3) the allocation of scarce means to satisfy competing ends”, Becker (1990:3).

O Homo oeconomicus, na qualidade de modelo de indivíduo da Economia, serviria de ponto de partida de modo a permitir a construção teórica necessária para avaliar uma das diversas facetas, ou papéis, que os seres humanos representamos diariamente quando têm que decidir como empregar os recursos à sua disposição.

Mas isso não significa que todas as situações e restrições utilizadas na construção da heurística que seria utilizada na tarefa de decidir seriam encontradas na ocasião da decisão e, ainda, se eventualmente poderiam vir a ser encontradas.

A decisão do Homo oeconomicus será sempre uma ação no futuro do pretérito (rectius a ação somente terá lugar no mundo real se as mesmas circunstâncias idealizadas em abstrato forem verificadas). Isto porque, por mais que a técnica seja empregada corretamente, existirá a probabilidade de, na época de transpor do planejado e do calculado para a ação, as condicionantes utilizadas não se comprovarem, ou surgirem outras não previstas. Não raro, o planejado inclui a antecipação ou a previsão de outras ações.

Como isso dificilmente será verdade, será sempre uma ação que ocorreria, mas que não necessariamente ocorrerá. Existe, portanto, uma clara distinção entre o agente, aquele que praticará a ação, e o Homo oeconomicus, aquele que a praticaria. 


\section{CAPÍTULO 2: A AUSÊNCIA DE UM MODELO DE INDIVÍDUO NA METODOLOGIA JURÍDICA E A SUA NECESSIDADE.}

Pode-se dizer que a ausência de estabilidade histórica no conceito de indivíduo possui reflexos na metodologia jurídica. São reflexos ainda mais profundos, pois acabam por permear o Direito como um todo, e a causa é uma só: a ausência de um modelo de indivíduo.

Por mais estranho que possa parecer, afinal, tal como a Economia o Direito é uma Ciência Humana, a metodologia jurídica não emprega esforços para definir qual seria o modelo de indivíduo que a ela seria central. Duas são as perguntas que acabam deixadas ao relento: quais são as características do indivíduo? Qual é a sua racionalidade?

A doutrina já abordou os modelos de indivíduo do Direito e a influência deste, naquele, fornecendo tratamentos distintos para o modelo de indivíduo e reiterando a problemática acerca da incerteza terminológica e o tratamento conceitual.

\subsection{Homo juridicus: algumas tentativas incompletas.}

\subsubsection{As posições de Del Vecchio e de Supiot.}

Da mesma forma que podem ser encontrados na doutrina os termos apresentados no capítulo anterior, também podem ser encontradas análises do Homo juridicus nas obras de dois autores. Contudo, não se encontra nos dois casos qualquer aspiração em utilizá-lo no centro de uma metodologia jurídica. São eles Giorgio Del Vecchio e Alain Supiot.

Seguindo o desenvolvimento da Economia, conforme afirma, Del Vecchio questiona a necessidade de se construir para o Direito o Homo juridicus, que seria o equivalente ao Homo oeconomicus.

O Homo juridicus seria um homem hipotético cuja conduta se pautaria (i) pela observância do Direito, mantendo-se dentro de seus limites sem violar nenhuma 
norma; (ii) pelo exercício de todos e qualquer direitos a ele conferidos, sem abrir mão de nenhum, levando-os ao limite e sem se deixar influenciar por outras normas além das jurídicas, como no caso da moral; (iii) pela defesa do Direito contra qualquer ameaça que possa surgir. Nas três hipóteses, o Direito seria o motivo fundamental de sua ação.

A conclusão do autor é que o Direito unicamente não é suficiente para regular a vida em sociedade, posto que existem outras normas que devem ser obedecidas. Ao observar unicamente o Direito, o Homo juridicus não aspiraria valores maiores, limitando-se a um comportamento ético mínimo. Além do que, defender unicamente o Direito representaria o abandono de todas as suas demais funções na sociedade, o que não seria um modelo a ser seguido.

Isto ocorreria porque todos os padrões éticos e morais seriam reduzidos à norma escrita, similarmente as leis que regulam a Física e a Química, perdendo a dimensão que faria com que o Homo juridicus abandonasse a sua essência humana. A visão de Del Vecchio, neste sentido, é parecida com a de Amartya Sen, que aponta um abandono da ética, e se aproximaria do canalha legalista, de André Comte-Sponville.

Del Vecchio incorre no mesmo erro que os dois autores apontados acima ao desconsiderar suas principais funções. Primeiro, que o Homo juridicus é um modelo de indivíduo e, por conseguinte, abstrato, sem qualquer relação social. Da mesma forma, o Homo oeconomicus é um recurso metodológico da Economia, e não uma um padrão de conduta que deve ser obrigatoriamente observado pelos seres humanos.

Segundo, pautar-se de acordo com o Direito ou com a Economia não significa relegar ao limbo todas as demais influências que são exercidas no processo decisório e na ação individual. Não existe impedimento em privilegiar-se o comportamento ético ou moral em detrimento da maximização de benefícios. Basta, para isso, que ao determinar a preferência individual determine qual deve ser buscada. Nestes termos a ação seria igualmente racional.

A visão de Supiot também não é compatível com o que se pretende. O autor centra sua análise na relação entre Direito e Justiça, do ponto do vazio deixado pela perda da fonte moral comumente aceita. A perda é decorrente da dificuldade de se 
garantir sua observância especialmente pelo avanço da sociedade e o afastamento contínuo entre Direito e moral.

A conseqüência da perda da fonte moral seria a redução do Direito a um conjunto de normas basicamente negociais que servem de substrato para os diversos tipos de contrato que regram as relações entre indivíduos e entre eles e as diversas instituições. Estas normas estariam reduzidas à técnica e seriam desprovidas de valor e significado.

O Homo juridicus de Supiot é um ser racional, sujeito de direitos, que produz e depende de certos dogmas culturais e crenças que estão sujeito as diferenças entre as diversas culturas. Mas não pode-se dizer que seja um modelo de indivíduo ou que possua conotação metodológica.

Portanto, nem Del Vecchio nem Supiot se encarregaram de fornecer, além de críticas contextualizadas, as características do Homo juridicus para fins metodológicos.

\subsubsection{Homo juridicus e Homo oeconomicus como entidades comunicativas.}

Fugindo a tradição humanística, mas fornecendo uma alternativa de tratamento do Homo juridicus e do Homo oeconomicus como modelos de indivíduo, poder-se-ia considerá-los como entidades comunicativas.

Foi isto o que Gunther Teubner e Michael Hutter, simpatizantes da Teoria dos Sistemas de Niklas Luhmann, propuseram. Neste sentido o Homo oeconomicus e o Homo jurdicus seriam ficções comunicativas, Teubner e Hutter (2000:569-584)

Para esta teoria, contrariando a visão sociológica mais tradicional, o homem não integraria o sistema social (ou qualquer um dos diversos sistemas sociais parciais), mas faria parte do ambiente e seria capaz de emitir comunicação, sendo, assim, uma entidade comunicativa. 
Logo, Homo juridicus e Homo oeconomicos seriam entidades comunicativas que emitiriam as comunicações características de seus sistemas parciais correspondentes.

Uma das formas de diferenciar e demarcar suas funções resulta do tratamento da Economia e do Direito como sistemas sociais. Neste caso, a sociedade seria vista como um sistema social global fechado composto por diversos sistemas sociais parciais, autopoiéticos e auto-referenciais, operacionalmente fechados e cognitivamente abertos ao mesmo tempo.

Cada sistema social parcial pode estar estruturalmente acoplado a outros sistemas sociais, todos passíveis de serem identificados e diferenciados entre si e em relação ao ambiente de acordo com a comunicação que ocorre no interior de cada um.

O processo de identificação e diferenciação da comunicação própria de um sistema social é feito por um observador segundo estrutura, código, função, programa e meio de comunicação simbolicamente generalizado, que são específicos para cada sistema social.

Assim, pode-se dizer que ao identificar e diferenciar as comunicações o que está sendo feito é a identificação e diferenciação dos diversos sistemas sociais, pois a comunicação característica de cada um confere a sua unidade. E cada sistema possui um código binário característico da comunicação empregada pelo sistema, juntamente com operações de reprodução específicas que conferem o fechamento operativo essencial a sua unidade, e sua abertura ao ambiente.

Os sistemas político, religioso, econômico e jurídico são alguns exemplos de sistemas sociais parciais que podem ser encontrados na sociedade, posto que cada um, no seu interior, possui certo tipo de comunicação e realiza determinada operação característica.

Conforme dito, cada sistema social parcial possui o seu próprio código particular e invariável. Ele serve para definir as condições sob as quais os participantes de um sistema podem nele participar, bem como para definir quem pode promover 
comunicação. E, ao comunicar, movimentam e reproduzem a operação típica do sistema. Além disso, o código reduz a complexidade das informações recebidas do ambiente.

Para o sistema econômico, os preços são programas de decisão e de variabilidade interna - os meios de comunicação que ocorrem no seu interior, e fornecem orientação sob a forma de informação a todos aqueles que a consideram relevante. Por sua vez, no sistema jurídico, os preços são substituídos pelas normas jurídicas.

O sistema econômico pode ser encarado como uma cadeia seqüencial de pagamentos e ao longo desta cadeia é transferido o seu sinal característico: o dinheiro. Por conta disto, em seu centro encontra-se o banco central. É o dinheiro que determina o seu código característico, sendo este ter/não-ter.

Por sua vez, no sistema jurídico, os pagamentos são substituídos pela aplicação das normas jurídicas aos casos concretos - a determinação do que é ou não Direito - e, conseqüentemente, os tribunais são substituídos pelo banco central, e o código passa a ser lícito/ilícito (direito/não-direito).

É desta forma que o sistema garante a sua continuidade. Pagamentos geram pagamentos por meio de pagamentos. As normas jurídicas geram normas jurídicas por meio de normas jurídicas.

Os preços permitem que os participantes observem os comportamentos dos demais e decidam a forma que atuarão. Neste sentido, fornecem as informações necessárias para a decisão, influenciando os pagamentos que são realizados no sistema econômico. No sistema jurídico, este papel é exercido pelas normas jurídicas ${ }^{17}$.

\footnotetext{
${ }^{17}$ Neste caso, adota-se o sentido amplo, no qual se entende como sendo norma jurídica os atos de vontade direcionados a conduta de outrem, o que inclui as normas contidas no ordenamento jurídico e os negócios jurídicos celebrados entre as partes. Poder-se-ia, inclusive, incluir neste conceito os costumes, os princípios gerais do Direito e a norma fundamental de Kelsen.
} 
O sistema social reage em relação ao seu ambiente. Assim sendo, se houver uma variação no preço de um bem ou serviço é porque aqueles que podem promover comunicação escolheram em fazê-lo desta forma.

Existe, por conseguinte, um filtro no ato de selecionar a comunicação relevante - o Homo oeconomicus selecionará, apenas, a comunicação relativa ao sistema econômico. O mesmo pode ser dito com relação ao sistema jurídico, cujo filtro é exercido pelo Homo juridicus.

O homem - o Homo oeconomicus ou o Homo juridicus - de acordo com a Teoria dos Sistemas, passa a ser parte do ambiente deixando de ser o elemento essencial da sociedade, sem, contudo, ser conduzido pelo sistema.

O sistema social seleciona a informação que irá comunicar de acordo com a sua relevância, para depois processá-la. A mensagem, que nasce do ato de comunicar, atua como veículo de transporte da informação.

Não há impedimento para que a informação selecionada seja diferente da informação emitida, vez que não há transmissão de informação e sim construção da informação pelo receptor, no processo de diferenciação entre mensagem e informação.

Conseqüentemente, a comunicação precedente pode ser diferente da nova comunicação. Contudo, para ocorrer comunicação é necessária a existência de uma comunicação anterior.

A adoção das premissas de racionalidade e de aspectos negativos do comportamento humano não rejeita a hipótese de comportamentos irracionais e positivos. A questão não parece ser essa e sim a presença do elemento subjetivo que impossibilita a constatação objetiva do comportamento verdadeiro.

Isto porque dado que os seres humanos são racionais, e, portanto, podem agir estrategicamente tomando por base o conhecimento prévio sobre o comportamento do outro, podem, de posse desta informação, simplesmente propositadamente adotar um 
determinado comportamento. Não há, porém, garantia de que a intenção decorrente da análise subjetiva deste comportamento seja idêntica a intenção pretendida pelo agente.

Essa é uma questão que aparentemente não possui solução, pois mesmo que seja possível mensurar objetivamente o comportamento do agente, a própria mensuração afeta o resultado, distorcendo-o, tal qual prevê o Princípio da Incerteza de Heisenberg.

A criação de modelos de indivíduo e mundos hipotéticos permite, se respeitado o seu "ambiente”, a hermetização necessária ao estudo da disciplina. Uma forma de eliminar a problemática relacionada com o Homo economicus e com Homo juridicus seria por meio da modificação de sua condição de centralidade e transformando-os em entidades de comunicação, como propõe a Teoria dos Sistemas.

Ao se fazer isto, a previsão será tão mais bem feita quanto a situação (não o modelo de indivíduo) for mais bem conhecida, dada a impossibilidade de se conhecer os aspectos subjetivos de todos aqueles que são representados pelos seus respectivos modelos ficcionais, ou mesmo de uma amostra representativa.

O Homo oeconomicus e, da mesma forma, o Homo juridicus, é ao mesmo tempo modelo de indivíduo e ficção necessária ao aspecto positivo das duas disciplinas, Economia e Direito, respectivamente. O propósito de cada um é desempenhar o comportamento padrão esperado que constitui o objeto da ação. Ao agir em relação ao objeto a comunicação é produzida.

No caso do sistema econômico o sinal é o dinheiro. É o dinheiro que quantifica a utilidade calculada pelo Homo oeconomicus. Contudo, os aspectos psicológicos, ou subjetivos, que levaram a ação não são conhecidos dos demais. Isto porque são dissociados da ação, perdendo a relevância no ato de comunicar. Assim, a comunicação passa a ser a quantificação da utilidade.

Para Jens Beckert (2002:9), “the strength of economic theory resides in the normative postulation of the connection between the action model of homo oeconomicus and a model of order derived from it in which efficient allocation 
equilibria prevail. Normative here means that recommendations for action can be derived from the theoretical models that imply how actors have to act if they want to optimize their individual utility, while the invisible hand of the market at the same time produces an equilibrium with optimal allocation of resources.”

Por outro lado, "in the complex situation of concrete human action, a transitive utility function would not be rational "because it is too rigid and does not correspond to the conditions of meaningful value orientation”, Beckert (2002:209).

E, ainda, “in Luhmann, giving up the rational-actor model, however, goes along with abandoning action theory itself and conceptualizing sociological theory as systems theory”, Beckert (2002:211).

A transformação do Homo juridicus e do Homo oeconomicus em entidades comunicativas resolve um dos pontos focais da problemática característica às Ciências Humanas: A subjetividade.

As preocupações acerca da racionalidade passam a ser secundárias e assumem aspecto mais objetivo. A comunicação foi realizada por quem poderia e no momento mais oportuno. Por outro lado, pelo abandono da subjetividade, não há como se utilizar uma entidade comunicativa como parâmetro para a medição de condutas. O mesmo pode ser dito com relação ao seu uso como modelo de indivíduo com intuito metodológico.

Possivelmente, Luhmann não tinha em mente ao idealizar a sua teoria a utilização de entidades comunicativas com este propósito.

\subsection{A necessidade de um modelo de indivíduo.}

Nunca é demais relembrar: o Direito é uma Ciência Humana e tem no seu centro o ser humano. Se este fato não for suficiente para concluir ser necessário um modelo de indivíduo, basta trazer à discussão a seguinte pergunta: quem é o destinatário do Direito posto? 
Se o acima for verdadeiro, não seria demais assumir que definir o modelo de indivíduo seria pré-condição para a formulação de enunciados e teoria e, conseqüentemente, para definir se definir a sua racionalidade. O mesmo poderia ser dito das normas jurídicas.

O processo de produção da norma jurídica não termina com o ato de vontade do legislador. Ele continua, passando pelo indivíduo e terminando no Julgador, provocado previamente para pôr fim a um conflito.

Pode-se dizer que quanto maior o conhecimento do Direito, maior a capacidade de o indivíduo controlar a possibilidade de surgimento de conflitos de interesse, ficando tais conflitos unicamente expostos ao auto-interesse, sendo este regulado pelo próprio Direito.

O motivo é simples. O Direito presume a onisciência. A onisciência engloba costumes, princípios gerais do Direito e, por extensão, a jurisprudência e os fatos que envolvem a conduta. Isso significaria que a informação disponível para a decisão e, conseqüentemente, para a sua ação tenderia a ser perfeita ${ }^{18}$. Neste sentido, não haveria erros nas decisões.

De modo a obrigar a realização do Direito, o legislador atribuiu ao Julgador, tal como o fez com o indivíduo, qualidades que somente poderiam ser encontradas em entidades ficcionais. Presumiu que o Julgador de carne e osso deve conhecer todo o ordenamento jurídico, estando obrigado decidir. Assim, o raciocínio e racionalidade seriam a ele inerentes.

\footnotetext{
${ }^{18}$ Somente será informação se esta alterar a percepção do agente com relação a determinado estado da natureza (uma situação). Os conceitos de informação perfeita, de informação completa e de certa informação para uma melhor compreensão, devem ser vistos no âmbito da Teoria dos Jogos. Quando os agentes (jogadores) possuírem a priori todas as informações necessárias antes de agir (jogar) incluindose: (i) a as regras, (ii) a estrutura do jogo, contendo as ações anteriores (não há perda de informações assadas) e as opções possíveis para agir a partir daquele ponto (informações futuras). Nesta situação, dizese que o jogador possui informação perfeita, Por sua vez, se os agentes possuírem, além das informações incluídas no conceito de informação perfeita, conhecimento das preferências (e do resultado esperado) do outro jogador, diz-se informação completa.
} 
A onisciência - o conhecimento perfeito - abrange todo o Direito. Abraça o ordenamento jurídico e os princípios gerais que o alicerçam e se estende para toda a sociedade, onde se encontram presentes os costumes, até atingir os indivíduos, que regulam suas condutas intersubjetivas.

É uma conclusão lógica que decorre da prescrição em diversos dispositivos, conforme pode ser visto no Decreto-Lei $\mathrm{n}^{0} 4.657$, de 4 de setembro de 1942, a Lei de Introdução ao Código Civil (LICC):

"Art. 4 - Quando a lei for omissa, o juiz decidirá o caso de acordo com a analogia, os costumes e os princípios gerais de direito.”

De forma parecida pode ser visto no Decreto-Lei $\mathrm{n}^{0}$ 5.452, de 1 de maio de 1942, a Consolidação das Leis do Trabalho (CLT):

“Art. 8 - As autoridades administrativas e a Justiça do Trabalho, na falta de disposições legais ou contratuais, decidirão, conforme o caso, pela jurisprudência, por analogia, por eqüidade e outros princípios e normas gerais de direito, principalmente do direito do trabalho, e, ainda, de acordo com os usos e costumes, o direito comparado, mas sempre de maneira que nenhum interesse de classe ou particular prevaleça sobre o interesse público.

Parágrafo único - O direito comum será fonte subsidiária do direito do trabalho, naquilo em que não for incompatível com os princípios fundamentais deste.”

Similarmente, na Lei 5.172, de 25 de outubro de 1966, o Código

Tributário Nacional (CTN), pode ser encontrado dispositivo similar.

“Art. 108 - Na ausência de disposição expressa, a autoridade competente para aplicar a legislação tributária utilizará sucessivamente, na ordem indicada:

I - a analogia;

II - os princípios gerais de direito tributário;

III - os princípios gerais de direito público;

IV - a eqüidade.

$\S 1^{\circ} \mathrm{O}$ emprego da analogia não poderá resultar na exigência de tributo não previsto em lei. 
$\S 2^{\circ} \mathrm{O}$ emprego da eqüidade não poderá resultar na dispensa do pagamento de tributo devido.”

E, ainda, na Lei $\mathrm{n}^{\circ}$ 8.078, de 11 de setembro de 1990, o Código de Defesa do Consumidor (CDC), possui dispositivo nesta mesma linha.

\begin{abstract}
“Art. 7- Os direitos previstos neste código não excluem outros decorrentes de tratados ou convenções internacionais de que o Brasil seja signatário, da legislação interna ordinária, de regulamentos expedidos pelas autoridades administrativas competentes, bem como dos que derivem dos princípios gerais do direito, analogia, costumes e eqüidade.
\end{abstract}

Parágrafo único. Tendo mais de um autor a ofensa, todos responderão solidariamente pela reparação dos danos previstos nas normas de consumo.”

O Julgador deverá ser onisciente para decidir. Mas não só. Deve empregar o raciocínio por analogia - um dos tipos possíveis de raciocínio. Esta onisciência tem duplo sentido: evitar a omissão e determinar se houve omissão prévia.

A sua capacidade cognitiva, além de compatível com a pressuposta onisciência, deve ser livre de erros. Não é por menos que Dworkin formulou o Juiz Hércules para criticar a imposição do legislador ${ }^{19}$ ao Julgador. Adicionalmente, deve procurar seguir a jurisprudência, evitando contradições e contrariedades que emanariam que seriam incompatíveis com o Poder originado do Estado.

Da mesma forma, há previsão semelhante para o indivíduo no Direito Pátrio, tanto do Direito Civil quanto no Direito Penal. Primeiramente, veja-se o contido na LICC:

"Art. 3 - Ninguém se escusa de cumprir a lei, alegando que não a conhece.”

E, no Direito Penal, no Decreto-Lei ${ }^{\circ}$ 2.848, de 7 de dezembro de 1940, o Código Penal (CP).

“Art. 21 - O desconhecimento da lei é inescusável. O erro sobre a ilicitude do fato, se inevitável, isenta de pena; se evitável, poderá diminuí-la de um sexto a um terço.”

\footnotetext{
${ }^{19}$ Neste caso não seria o Legislador Racional que busca o seu igual?
} 
Se o desconhecimento da lei é inescusável, resta ao indivíduo conhecê-la para ter ciência de seus efeitos e guiar conscientemente suas ações e minimizar a probabilidade de determinada sanção.

Para minimizar essa probabilidade, o indivíduo dever ser capaz de raciocinar da mesma forma que o Julgador, tendo, portanto, a mesma onisciência. Mas não só. Se o contrário fosse possível, a conseqüência obrigatória seria admitir a possibilidade de formação de uma sociedade formada por indivíduos que possivelmente agiriam contrariamente ao ordenamento jurídico, contrariando o pressuposto do indivíduo racional e impossibilitando o controle social por meio do Direito.

Se o legislador (no caso, o Legislador Racional que será apresentado mais adiante) buscou consolo à sua solidão no Julgador, pode-se dizer que, ao prescrever desta forma, o legislador igualou Julgador e indivíduo.

Os dois possuiriam as mesmas informações, como conseqüência da publicidade obrigatória das normas jurídicas. E o processamento de todas estas informações requer capacidade cognitiva ilimitada. O Direito seria, assim, formado por entidades ficcionais.

A onisciência do Julgador e do indivíduo com relação ao ordenamento jurídico pode ser vista, para o primeiro, como sendo o pressuposto necessário para decidir os conflitos sociais, e, para o segundo, como uma forma de evitá-los. Não seria factível admitir falha cognitiva para o Julgador e para o indivíduo sem prejudicar a realização do Direito ou afrontar o pressuposto da razão.

Além disso, sem esse pressuposto seria aberto o espaço para o surgimento dos problemas advindos do relativismo quanto à ignorância, pela exata impossibilidade de se graduar o nível de conhecimento individual.

Adicionalmente, ao se enfraquecer o pressuposto da onisciência a incerteza de decisão e até mesmo a omissão passariam a ser admitidas. Estas, incompatíveis com a necessidade de realização do Direito. Nesse caso, o caráter probabilístico do Direito se somaria a incerteza de decisão. 
Julgador e indivíduo agem. A ação, neste caso, é vista como uma conseqüência obrigatória da decisão consciente nos moldes da lei e por esta impulsionada.

O ordenamento jurídico determina que o Julgador decida, despache e tome providência no curso do processo e para o andamento deste. Da mesma forma, que o individuo, amparado pelo Princípio da Legalidade insculpido no art. 5, II, da Constituição Federal de 1988, faça ou deixe de fazer alguma coisa.

No caso do Julgador, a obrigatoriedade da decisão - vedação ao non liquet - não é novidade no sistema de Direito Romano-Germânico. Pode-se dizer que surgiu no Direito Positivo brasileiro por influência do Código Francês de 1804, mais precisamente do seu artigo quarto.

Segundo este artigo, o juiz poderia ser processado por denegação de justiça caso não decidisse. Afinal o juiz seria - como ainda é hoje - onisciente.

“Le juge qui refusera de juger sous prétexte du silence, de
l'obscurité ou de l'insuffisance de la loi, pourra être poursuivi
comme coupable de déni de justice.”

É, como ainda e hoje, uma tarefa hercúlea e somente seria possível se o juiz fosse onisciente ${ }^{20}$, uma dentre outras qualidades. O conhecimento prévio da informação é condição necessária à vedação do non liquet. Não há decisão consciente sem o conhecimento prévio da informação necessária, e a decisão no âmbito do Direito precisa ser consciente, caso contrário não produzirá efeitos ou a sanção decorrente poderá ser afastada.

Ao presumir a onisciência tanto para o Julgador quanto para o indivíduo, o legislador presumiu uma sociedade com um mínimo de assimetria de informações e de conflitos sociais. Isso porque os indivíduos levariam em conta ao decidir

\footnotetext{
${ }^{20}$ Apesar de oniscientes, as onisciências do indivíduo, do legislador e do magistrado possuem origens distintas.
} 
conscientemente todas as informações necessárias e relevantes. Quando houvesse infração ao Direito, os conflitos sociais seriam resolvidos da mesma forma, de acordo com os mesmos diplomas legais. Logo, onisciência e obrigatoriedade de decisão caminham juntas.

De modo a instrumentalizar a onisciência, a obrigatoriedade de decisão está igualmente prevista no ordenamento jurídico. Na LICC, expressamente, o mesmo artigo que trata a obrigatoriedade de onisciência, trata da obrigatoriedade de decisão:

“Art. 4 - Quando a lei for omissa, o juiz decidirá o caso de acordo com a analogia, os costumes e os princípios gerais de direito.”

Textualmente na Lei $\mathrm{n}^{0}$ 5.869, de 11 de janeiro de 1973, o Código de Processo Civil (CPC), com modificação introduzida pela Lei ${ }^{0}$ 5.925, de 1 de outubro de1973:

\begin{abstract}
“Art. 126 - O juiz não se exime de sentenciar ou despachar alegando lacuna ou obscuridade da lei. No julgamento da lide caber-lhe-á aplicar as normas legais; não as havendo, recorrerá à analogia, aos costumes e aos princípios gerais de direito.”
\end{abstract}

E, ao contrário do que se esperaria, pois recai sobre a liberdade individual, no Processo Penal não há previsão legal expressa sobre o non liquet. A obrigatoriedade de decisão é implícita e decorre da necessidade de absolvição do réu quando não for possível condená-lo. Dito de outra forma, na inexistência de informação suficiente que prejudique a decisão contrária ao réu, este deve ser absolvido.

Nos dois casos, absolvição e condenação pressupõem uma decisão por parte do Julgador. É o que se depreende do Decreto-Lei ${ }^{\circ} 3.689$, de 3 de outubro de 1941, o Código de Processo Penal (CPP), com as alterações introduzidas pela Lei $\mathrm{n}^{\circ}$ 11.690, de 2008 e pela Lei $n^{\circ} 11.719$, de 2008.

\footnotetext{
“Art. 386 - O juiz absolverá o réu, mencionando a causa na parte dispositiva, desde que reconheça:

I - estar provada a inexistência do fato;

II - não haver prova da existência do fato;

III - não constituir o fato infração penal;
} 
IV - estar provado que o réu não concorreu para a infração penal;

V - não existir prova de ter o réu concorrido para a infração penal;

VI - existirem circunstâncias que excluam o crime ou isentem o réu de pena (arts. 20, 21, 22, 23, 26 e $\S 10$ do art. 28, todos do Código Penal), ou mesmo se houver fundada dúvida sobre sua existência;

VII - não existir prova suficiente para a condenação.

Parágrafo único. Na sentença absolutória, o juiz:

I - mandará, se for o caso, pôr o réu em liberdade;

II - ordenará a cessação das medidas cautelares e provisoriamente aplicadas;

III - aplicará medida de segurança, se cabível.”

“Art. 397. Após o cumprimento do disposto no art. 396-A, e parágrafos, deste Código, o juiz deverá absolver sumariamente o acusado quando verificar:

I - a existência manifesta de causa excludente da ilicitude do fato;

II - a existência manifesta de causa excludente da culpabilidade do agente, salvo inimputabilidade;

III - que o fato narrado evidentemente não constitui crime; ou

IV - extinta a punibilidade do agente.”

O pressuposto da onisciência é uma condição metodológica necessária a vedação ao non liquet, sem ela qualquer teorização sobre a dogmática da decisão estaria prejudicada. Mas esta mesma condição representa um paradoxo.

Isto porque admitir que Julgador, indivíduo e legislador podem conhecer todas as verdades sobre tudo aquilo que já existe e venha a existir é uma impossibilidade mesmo em se tratando de entidades abstratamente consideradas. Tratase de um paradoxo - o "Paradoxo da Onisciência” (Paradox of Oniscience).

Segundo Patrick Grim, são os seguintes, de forma resumida, os argumentos contra a possibilidade de onisciência. 
Primeiro, que não há um conjunto contendo todas as verdades, Grim (1984:206-207) e Grim (1988a:356). Segundo, que este ser onisciente seria autoreflexivo, Grim (1988a:354). Terceiro, que se existir um ser onisciente, este ser constituiria um conjunto de todas as verdades, Grim (1988a:356). A conclusão do autor, é que não é possível haver um ser onisciente, nem mesmo abstrato.

Como exemplificar este paradoxo? Suponha-se a existência de um livro contendo todas as verdades sobre um determinado assunto. Existiriam tantos livros quanto o número de assuntos existentes. Um livro conteria as verdades contidas nos demais livros. Mas qual livro conteria as verdades contidas no livro que contém todas as verdades, visto que ele é, também, um livro? Assim, seria sempre necessário outro livro para conter as verdades do livro que contém todas as verdades, caso contrário o mesmo livro deveria conter todas as verdades dos demais livros e as contidas em si mesmo.

Um ser ou uma entidade abstrata, para ser onisciente, deveria ser capaz de conter todas as verdades existentes, inclusive sobre si mesmo. O que representa uma impossibilidade.

Outro paradoxo que deixa ainda mais clara a impossibilidade de onisciência é o chamado "Paradoxo do Conhecedor" (Paradox of the Knower, ou simplesmente, The Knower, ou, ainda The Epistemic Paradox), e Grim também forneceu uma versão para ele, demonstrando ser, da mesma forma, impossível admitir a possibilidade de onisciência.

Uma forma de exemplificar este paradoxo é a seguinte: "I cannot know that Jane is not married unless it is true that she is not married. And I cannot but know that, if I know Jane is not married, then she is not married. Anyone who understands what knowing is knows that what is known is true”, Clark (2007:107).

Não há como se admitir a onisciência nem a possibilidade de um ser onisciente, ainda que ficcional. Nestes termos, a proibição do non liquet, visto que a onisciência é uma condição necessária, não se sustenta, sendo, por conseguinte, apenas uma ficção jurídica necessária ao controle social. 
Com relação ao indivíduo basta, por enquanto, dizer que juntamente com a pressuposição de ele ser racional, que a onisciência é necessária para o controle social a ele exercido, pois permite a previsão das ações individuais. Além disto, tais pressupostos são indispensáveis para que a lei seja cumprida. O mesmo pode ser dito com relação ao Julgador, porém, por outro ângulo. Eles seriam necessários para a aplicação da lei e solução dos conflitos.

Por conta do acima, o próprio Direito segrega ao tratar diferenciadamente aqueles cuja capacidade cognitiva não é perfeita, levando à interpretação errônea ou ao desconhecimento do Direito. O error juris seria o reconhecimento de falha no processo cognitivo.

O Julgador possui abrigo semelhante. A inafastabilidade do controle pelo Judiciário, a sistemática recursal e o duplo grau de jurisdição permitem correções no processo cognitivo do Julgador.

Logo, a igualdade cognitiva com que o Direito trata indivíduo e Julgador corrobora com a determinação dos destinatários do próprio Direito.

\subsection{A pessoa como destinatária do direito posto.}

O ordenamento jurídico cria e conceitua os sujeitos que serão titulares de direitos e obrigações, e o faz centrando o Direito na pessoa, uma ficção por ele criada.

Não é todo ser humano que é capaz de ser titular de direitos e obrigações, somente aqueles que o Direito diz serem é que são. E o Direito faz isto através da pessoa, mas trata casos excepcionais. O nascituro, uma expectativa não realizada de vida, ainda não é uma pessoa juridicamente considerada, mas seus direitos são preservados.

Um primeiro passo e, também, fonte de confusão, seria entender que o modelo de indivíduo do Direito seria a pessoa, conceito criado pelo próprio Direito. Primeiramente, pessoa, indivíduo, sujeito e ser biológico - o ser humano - não se confundem. 
Para o momento interessa o conceito de pessoa, no caso o de pessoa física ou natural dotada de personalidade. A pessoa física é o começo de tudo, a unidade básica, pois sem ela não se pode conceber a pluralidade - a pessoa jurídica, a coletividade e, até mesmo, o Estado.

Ela é uma criação do Direito resultante da intercessão de diversas normas presentes no ordenamento jurídico. Ou, como disse Kelsen, “a chamada pessoa física não é, portanto, um indivíduo, mas a unidade personificada das normas jurídicas que obrigam e conferem poderes a um e mesmo indivíduo. Não é uma realidade natural, mas uma construção jurídica criada pela ciência do Direito, um conceito auxiliar na descrição de fatos juridicamente relevantes”, Kelsen (2003:194).

Para Gustav Radbruch o conceito de pessoa traz consigo a noção de igualdade. Pois todos, independentemente do papel social ocupado, seriam iguais perante o Direito. Esta igualdade serviria de denominador comum, e sem ela não seria possível qualquer consideração de Justiça. E, na mesma linha de Kelsen, “A igualdade jurídica, a mesma capacidade jurídica que forma a essência da pessoa, não é inerente aos homens e às associações humanas, mas lhes é atribuída posteriormente pelo ordenamento jurídico. (...) Ser pessoa é resultado de um ato de personificação da ordem jurídica. Todas as pessoas, tanto as físicas quanto as jurídicas, são criações da ordem jurídica, ” Radbruch (2004:191). E adiciona-se: são ficções jurídicas.

É o ordenamento jurídico posto pelo Estado - ou, melhor, o discurso jurídico - que determina o conceito de pessoa. Não seria necessário ressaltar a necessidade de estabilidade e a obrigatória proteção deste conceito contra ideologias e interesses dominantes.

Alterações no conceito de pessoa permitiram desde a sua "coisificação" até atrocidades.

Historicamente os escravos não eram reconhecidos como pessoas pelas diversas legislações, não tendo, por conseguinte, direitos, e sendo tratados como coisas. 
Na primeira metade do século XX, a chamada "Solução Final”, colocada em prática pelos nazistas durante a $2^{\text {a }}$ Grande Guerra, seguiu caminho parecido. Sua origem pode ser traçada às diversas modificações do conceito de pessoa que, ao longo do tempo, foram introduzidas na Alemanha hitlerista.

Ainda no século passado, a mulher não podia votar, não tinha capacidade jurídica plena, estando sujeita ao marido, chefe da casa - um resquício do pater familias de outrora.

Pela fragilidade e impossibilidade de unificar o conceito de pessoa nos diversos ordenamentos jurídicos vigentes nos diferentes países, de modo a permitir a atribuição de um conjunto mínimo de direitos reconhecido universalmente, é que os Direitos Humanos têm sua eficácia questionável. Ou será que uma mulher vivendo em algum país do Oriente Médio possui os mesmos direitos e tratamento de sua igual vivendo no Ocidente?

São todas possibilidades e reflexos que decorrem da fragilidade do conceito de pessoa, cujas alterações são conseqüências de influências externas ao Direito, as quais resultam em instabilidade. Influências, por assim dizer, que podem ser traduzidas por interesses econômicos, morais, religiosos e disputas de poder.

O conceito de pessoa - instável, mutável e frágil - não pode (pelo menos não deveria) ser utilizado com finalidade metodológica, servindo de base para construir um modelo de indivíduo dotado de racionalidade jurídica. Mas, ao mesmo tempo, não se pode deixar de lado que o Direito influencia na criação do modelo de indivíduo.

Será que um garoto de dez anos, uma criança, que sozinha gasta o dinheiro mensalmente recebido dos pais e avós na compra de figurinhas ou brinquedos, pode ser considerada um Homo oeconomicus? Afinal, nesta situação, ele desempenhou o papel de agente econômico: a criança está alocando seus recursos entre fins alternativos (aquisição de figurinhas ou brinquedos), mas decerto não possui o mesmo discernimento que um adulto, nem mesmo capacidade jurídica para tal. 
O Direito impõe os limites para determinar quem seria, ou deveria ser considerado um agente econômico ${ }^{21}$. Homo oeconomicus ${ }^{22}$. E mais, será que apenas o Homo - homem - pode ser considerado um agente econômico? Onde estaria a Femina oeconomica?

Não há, no Direito atual, qualquer limitação para que a mulher conclua negócios jurídicos e administre seu patrimônio, ou mesmo qualquer diferenciação entre os sexos neste sentido, tal como existia durante a vigência do Código Civil de 1916, espelhando a moral vigente à época.

Que o Direito é uma instituição social, não há dúvida. Só é possível conceber Direito numa sociedade que o reconhece como uma de suas instituições. Se, por um lado, ele exerce o papel de restrição às ações, direcionando-as por meio de influência no processo de decisório, por outro ele determina a criação de modelo de indivíduo.

Não seria admissível a construção de um modelo de indivíduo que confrontasse com o Direito, da mesma forma que não é há como conceber o agente econômico onde não há Economia ou comércio.

Veja-se o que disse Walter Bagehot (1908:105-106), "On the other hand, no intellectual attempt can be more absurd than the attempt to apply the conclusions of our Political Economy to the lives of nations at a non-commercial stage of their existence. (...) The money-getting element is a most subordinate one in their minds; its effects are very subordinate ones in their lives. (...) But only in communities where the commercial element is the greatest element, will these effects be the greatest. In so far as nations are occupied in "buying and selling" in so far will Political Economy, the exclusive theory of men buying and selling, come outright, and be true of them”.

\footnotetext{
${ }^{21}$ Agente econômico seria espécie, da qual são gêneros, no masculino, Homo oeconomicus (economic man ou homem econômico) e, no feminino Femina oeconomicus (economic woman ou mulher econômica). O conceito de agente econômico reuniria os dois gêneros.

${ }^{22}$ Segundo a crítica feita pela Feminist Economics, os modelos econômicos refletem o gênero masculino, não incorporando o feminino. Neste sentido ver: NELSON, Julie. Feminism and economics. Journal of Economic Perspectives, v.9, n.2, 1995, p. 131-148.
} 
E, novamente, “At first sight it would seem that this limitation of abstract Political Economy would exclude it from much of the real world .(...) The nature of the "man" who first occupied new countries did not "conform" to the standard of economic man; the being of reality was not the being of the hypothesis. The first men, all researches justify us in assuming, nearly approached in nature to the present savage man”, Bagehot (1908: 109).

Direito e Economia não se confundem. São duas disciplinas autônomas do conhecimento humano, mas que se influenciam mutuamente. Não se adquire um bem sem um negócio jurídico; não se aliena um bem sem um negócio jurídico. É o Direito que garante a propriedade e permite a sua transferência a outrem.

\subsection{Raciocínio jurídico versus racionalidade jurídica: plano concreto versus plano abstrato.}

Mesmo na ausência de modelos de indivíduo, a metodologia jurídica procura teorizar sobre a racionalidade jurídica. Ao fazer isto, racionalidade e raciocínio são muitas vezes utilizados como sinônimos e a linha que separa ambos é apagada.

De modo a teorizar sobre a racionalidade, é indispensável que se aborde a decisão e o método que a esta antecede. O método é indispensável na solução de problemas e, porque não, de controvérsias.

Os problemas são apresentados em âmbitos específicos e devem ser solucionados pelos diversos agentes que neles se encontram envolvidos. Logo, a decisão é particular. Não pode ser genérica e atribuível a todos os agentes que podem ser encontrados no Direito.

Apesar disto, grande esforço é dedicado pela metodologia jurídica ao teorizar sobre a realização do Direito. Esta, por sua vez, se encontra indissociavelmente ligada ao fenômeno do Poder por meio de uma racionalidade jurídica reduzida basicamente à argumentação (a argumentação jurídica) direcionada a uma finalidade. Devido ao seu caráter argumentativo, grande ênfase é dada à técnica retórica. Racionalidade seria, assim, sinônimo de raciocínio. 
Neste aspecto, racionalidade é confundida com raciocínio, mas a finalidade da metodologia jurídica é invariavelmente a análise do processo decisório do Julgador.

Por exemplo, de acordo com Tércio Sampaio Ferraz Jr. (2003:316), “a doutrina costuma, tradicionalmente, encarar a decisão jurídica, sobretudo, como problema da construção do juízo deliberativo pelo juiz, mas também pelo administrador, pelo legislador, pela autoridade em geral.”

Em termos parecidos, encontra-se em Antonio Castanheira Neves (1993:17) que “à metodologia jurídica compete refletir criticamente o método da judicativo-decisória realização do direito”.

Apoiado em dois renomados doutrinadores não seria imprudente assumir que a metodologia jurídica emprega grande esforço em teorizar sobre a decisão judicial, sendo esta central àquela.

Um dos primeiros equívocos decorrentes da falta de um modelo de indivíduo seria confundir raciocínio de racionalidade. São dois vocábulos distintos, mas que estão relacionados. Segundo o "Novo Dicionário Aurélio”:

"raciocínio. [do lat. ratiociniu.] S. m. 1. Ato ou efeito de raciocinar. [Sin., p. us.: racionalização e raciocinamento.] 2. Encadeamento, aparentemente lógico, de juízos ou pensamentos. 3. Capacidade de raciocinar; juízo, razão; racionalidade: (...) 4. Lóg. Processo discursivo pelo qual se passa de proposições conhecidas ou assumidas (as premissas) a outra proposição (a conclusão) à qual são atribuídos graus diversos de assentimento; argumento. (...)”

“racionalidade. [do lat. tard. rationalitate.] S. f. 1. Qualidade de racionável ou de racional. 2. V. raciocínio (3). 3. Filos. Numa perspectiva dialética, a qualidade, socialmente construída, da atividade humana que é adequada às finalidades visadas. [Sin. ger.: racionabilidade]”

E, também, de acordo com o “Dicionário Houaiss”,

“raciocínio. [ lat. raciocinìum,ìi 'cálculo, avaliação'; ver rat-] S. $\boldsymbol{m}$. $\mathbf{1}$ ato ou efeito de raciocinar. 2. Exercício da razão através do qual se procura alcançar o entendimento de atos e fatos, se formulam idéias, e elaboram juízos, se deduz algo a partir de uma 
ou mais premissas, se tiram conclusões. 3. capacidade de raciocinar. 4. Rubrica: lógica. atividade mental que, por meio de instrumentos indutivos ou dedutivos, fundamenta o encadeamento lógico e necessário de um processo argumentativo, esp. no interior de demonstrações científicas, filosóficas ou matemáticas.”

“racionalidade. [lat. rationalitas,átis 'faculdade de raciocinar'; ver rat-; f.hist. 1813 racionalidáde] S. f. 1. qualidade ou caráter do que é racional, lógico. 2. capacidade de exercer a própria razão (...). 3. propensão para encarar fatos e idéias de um ponto de vista puramente racional (...). 4. Rubrica: matemática. propriedade de um ser racional (falando-se de um número, variável ou função).”

Na língua portuguesa, ambos os vocábulos não se confundem e possuem, inclusive, origem etimológica distinta. Todavia, é possível dizer que raciocínio poderia ser utilizado no sentido de racionalidade, por ser mais amplo, pois o primeiro possui como um de seus sentidos, o segundo, mas sempre num âmbito restrito - o domínio puro da razão.

Para afastar qualquer dúvida, veja-se que a mesma distinção é mantida em pelo menos três outras línguas neolatinas.

Na língua francesa, raciocínio pode ser traduzido por raisonnement e racionalidade por rationalité. Assim sendo, de acordo com o dicionário “Grand Robert”, na língua francesa, os vocábulos possuem respectivamente os seguintes sentidos:

\footnotetext{
"raisonnement (...) n. m. ÉTYM. 1380 au sens 1; dér. de raison. L’activivé, l'exercice de la raison (I., A., 1) discursive. Composition (des concepts), logique, méthode, raison. 2; (1636) Un, des raisonnements. Activité de l'esprit qui passé, selo des principles determines, d'un jugement à un autre, pour aboutir à une conclusion (...).”

"rationalité (...) n. f. ÉTYM. 1834; racionalité $<<$ activuté rationnelle >>, fin XIII; du latin. rationalis $<<$ rationnel $>>$. Didact. Caractére de ce qui est rationnel.”
}

Na língua espanhola, raciocínio pode ser traduzido por raciocínio, razón, razonamiento, deducción, ponderación. Destes, o mais próximo dos sentidos verificados nos idiomas anteriores é raciocínio. Por sua vez, racionalidade possui, como nos predecessores, uma única tradução, sendo ela racionalidad. Conforme é encontrado no "Diccionario de La Lengua Española”, os vocábulos possuem os seguintes sentidos: 
“raciocínio. (Del lat. ratiocinium) 1.m. Facultad de raciocinar.

2.m. Acción y efecto de raciocinar. 3.m. Argumento o discurso.”

“racionalidad. (Del lat. rationalitas, -atis) 1.f. Cualidade de racional.”

Na língua italiana o mesmo se repete. Raciocínio uma vez mais possui diversas traduções possíveis, sendo elas raziocinio, ragionamento, logica, ragione. Dentre elas, a tradução mais próxima e que mantém semelhança de sentido com os demais é raziocinio. Racionalidade, mais uma vez, possui uma única tradução possível: razionalitá. De acordo com o "Dizionario Interativo Etimologico Zanichelli”, os sentidos possíveis são:

"raziocinio. s. m. 'facoltà di esercitare la ragione in modo equilibrato' (av. 1600, G. Bruno), est. 'ragione' (av. 1712, L. Magalotti), 'ragionamento' (av. 1600, G. Bruno). (...) Vc. dotta, lat. ratiociniu(m), der. dal v. ratiocinari, propr. 'far di conto (ratio)' col suff. proprio di parecchi n. d'azione -cinium (-cinari per il v.): A. Ernout, Des composés latines en -cen, -cinium, et -cino(r), in Philologica, Paris, 1946, pp. 73-82. Per la fortuna della famiglia nel Settecento V. Fogarasi Parole passim.”

“razionalità. s. f. 'facoltà di ragionare' (1588, L. Salviati), 'l'essere razionale, comprensibile dalla ragione’ (av. 1406, F. Buti), 'l'essere concepito con un criterio razionale, perfettamente rispondente allo scopo' (1959, Diz. enc.), (mat.) 'proprietà di una grandezza di essere esprimibile con un numero razionale' (1959, Diz. enc.), (...) Vc. dotta, lat. rationale(m), da ratione(m) nel doppio sign. di 'conto' e 'ragione' (cfr. le accez. mat., che si rifanno al valore di ratio, come 'rapporto'). "L'aggettivo ragionevole esprime una sfumatura troppo caratterizzata ("capace di ragionare”) per poter servire di aggettivo di relazione a ragione in una lingua piuttosto precisa; i filosofi debbono ricorrere a razionale, e vi sono ricorsi fino dal Duecento" (B. Migliorini in Mél. Bally 254). Di qui il razionalismo con i suoi der., entrati nella terminologia filos. intern. a partire dal Settecento. Rationalitate(m) appartiene al lat. tardo (av. 240 d.C., Tertulliano). Razionalizzare ripete il fr. rationaliser, il quale, peraltro, nel senso di 'applicare i metodi della razionalizzazione ad un'impresa', non risale al 1907, come dichiara il FEW (Travaux de ling. XXIV [1986] 230).”

Como se não bastassem possuírem raízes etimológicas distintas, também é possível dizer que o sentido do vocábulo raciocínio é mais amplo do que o sentido do vocábulo racionalidade, tendo este último sentido específico.

O sentido de racionalidade está diretamente relacionado com o processo desenvolvido por aquele que tem capacidade de empregar a razão, de forma lógica, 
coerente e direcionada à determinada finalidade, não admitindo influências outras ditas “não racionais”, apenas o emprego da razão puramente considerada e isolada. Para fazêlo, necessita estar associada a um determinado método.

Assim, será assumido que raciocínio é espécie, enquanto racionalidade é gênero, e esta pode ser dividida ao menos em dois tipos. Racionalidade teórica (ou epistêmica) e racionalidade prática.

A primeira diz respeito ao que é racional acreditar, enquanto a segunda com o que é racional fazer, envolvendo normas para a realização de escolhas. Mele e Rawlings (2004:3-5). Adicionalmente é possível identificar um subtipo de racionalidade prática, a chamada racionalidade instrumental, melhor identificada com a Economia.

Dificilmente, mesmo com o avançar da Medicina, será encontrado na natureza um ser humano puramente racional, que consiga isolar completamente razão de emoção.

Esta "pureza” da razão, a qual permitiria o decidir sem qualquer interferência não racional, é um mero exercício de abstração e que serve a propósitos unicamente metodológicos para a construção dos alicerces de determinadas ciências, em especial nas Ciências Humanas.

Portanto, para admitir a possibilidade de emprego da racionalidade é necessário vinculá-la a um modelo de indivíduo abstrato, uma ficção de ser humano. Na Economia, o Homo oeconomicus é este modelo de indivíduo, o qual é dotado de racionalidade instrumental, e cuja "existência” foi concebida para o desenvolvimento de teorias envolvendo a decisão ou o propósito decisório.

Ao contrário do que atualmente defende a Sociologia Econômica ao criticar a correspondência entre o Homo oeconomicus e a sua contrapartida no mundo real, e a aplicação da racionalidade econômica em outros ramos do conhecimento humano além da Economia, entende-se que o Homo oeconomicus está presente no Direito. Todavia, a sua transposição para o Direito somente seria possível se certos pressupostos tradicionalmente utilizados na Economia forem flexibilizados. 
Não se pode afirmar que o ser humano é pura e unicamente racional, porém esta afirmação, ou melhor, esta pressuposição é uma necessidade das Ciências Humanas, em especial naquelas que tem por fundamento prescrever, determinar ou normatizar as condutas humanas com o propósito de possibilitar o direcionamento do comportamento humano, e com isto prevê-lo. Previsão esta indispensável para o exercício de qualquer forma de controle social.

Raciocínio e racionalidade, apesar de relacionados, estão em planos distintos. O raciocínio somente pode ser admitido para o ser humano existente na natureza, sendo imprescindível a presença de atividade mental.

Por seu turno, a racionalidade é marcantemente uma atividade de cálculo, sendo, portanto, dispensável a presença de atividade mental ${ }^{23}$. Conseqüentemente, pode ser concebida abstratamente e vinculada a um modelo de indivíduo. Modelo este que será utilizado para alguma finalidade relacionada ao mundo real, mas cuja principal virtude é a simplificação. Assim, a racionalidade precederia uma ação no futuro do pretérito, pois esta está condicionada à verificação da presença ou ausência das condições inicialmente estipuladas.

No campo unicamente do Direito, o raciocínio é marcantemente argumentativo, enquanto a racionalidade somente seria concebível se vinculada a um modelo de indivíduo.

Este modelo de indivíduo serviria ao mesmo tempo como ponto de partida para a decisão e como instrumento argumentativo na construção de raciocínios, e também garantir a estabilidade de seu uso. Algo que não se pode garantir pela ausência de mecanismos de controle de consistência da argumentação e da aplicação dos conceitos.

\footnotetext{
${ }^{23}$ Poder-se-ia dizer em contrário que para uma máquina executar um determinado cálculo é necessário que alguém a tenha programado para fazê-lo. E esta programação requer atividade mental. Portanto, todo cálculo, ainda que executado por uma máquina requereria em algum momento atividade mental. Neste aspecto se igualaria ao raciocínio, vez que tanto a racionalidade quanto o raciocínio seriam dependentes de atividade mental. Contudo, a atividade mental empregada para a programação do cálculo pode ter origem em outra pessoa, não necessariamente naquela que, em tese, faria o cálculo. Já no raciocínio isto não seria possível, pois é inerente àquele que raciocina.
} 
Partindo desta divisão, as atividades exercidas ou desenvolvidas pelo Julgador, indivíduo e legislador estão limitadas ao raciocínio jurídico. Neste, a razão não é predominante - apesar de o raciocínio ser exercício da razão - e sofre outras influências. Além do que, a coerência lógica das premissas é secundária e a manutenção da estabilidade dos sentidos não é observada em todos os raciocínios.

Esta demarcação entre raciocínio e racionalidade ressalta a discussão sobre ser o Direito fundamentalmente argumentativo ou se seria passível de nele ser aplicado o método hipotético-dedutivo, tal como é feito na Economia. As duas hipóteses estão diretamente ligadas ao tipo de raciocínio predominante e os limites de cada um, mas ambas pressupõe atividade mental direcionada e realizada em primeira pessoa.

A atividade mental está sujeita à influência de elementos extrajurídicos e subjetivos, como às limitações particulares ao Julgador e do indivíduo. Sofre, ainda, a interferência de teses, ideologias, impulsos, valores morais, e, porque não dizer de suas preferências, tendo em vista a possibilidade de escolha.

Para Chaim Perelman (2004:1), a palavra raciocínio “designa tanto uma atividade da mente quanto ao produto dessa atividade. A atividade mental de quem raciocina pode ser objeto de estudos psicológicos, filosóficos, sociais e culturais. Estes poderão revelar as intenções, os móbeis de quem elaborou um raciocínio, as influências de toda espécie que ele sofreu e que permitem situar o fenômeno em seu contexto.”

Segundo este autor, o raciocínio pode ser de dois tipos. Analítico ou dialético. "Os raciocínios analíticos são aqueles que, partindo de premissas necessárias, ou pelo menos indiscutivelmente verdadeiras, redundam, graças a inferências válidas, em conclusões igualmente necessárias ou válidas. Os raciocínios analíticos transferem à conclusão a necessidade e a verdade das premissas: é impossível que a conclusão seja falsa, se o raciocínio foi feito corretamente, a partir de premissas corretas”, Perelman (2004:1).

Por sua vez, os "raciocínios dialéticos (...) se referem, não às demonstrações científicas, mas às deliberações e às controvérsias. Dizem respeito ao meio de persuadir e de convencer pelo discurso, de criticar as tese dos adversários, de 
defender e justificar as suas próprias, valendo-se de argumentos mais ou menos fortes”, Perelman (2004:2).

Soma-se ao raciocínio analítico e ao raciocínio dialético, o silogismo dialético. Neste, “não são enunciadas todas as premissas - subentende-se que são conhecidas ou aceitas pelo auditório - e aquelas em que nos fundamentamos seriam apenas verossímeis ou plausíveis: a estrutura do raciocínio dialética seria, quanto ao resto, a do silogismo”, Perelman (2004:2).

Assim, conclusão e decisão não se confundem. A conclusão é o resultado obrigatório do raciocínio desenvolvido por meio de silogismos formulados com premissas necessárias ou verdadeiras. É marcante, portanto, no raciocínio analítico, podendo estar da mesma forma presente na racionalidade.

A decisão, ao contrário, não parte do mesmo tipo de premissas (necessárias ou verdadeiras) para a construção de silogismos, mas de opiniões formuladas argumentativamente por meio de inferências. Inferências estas que, no âmbito do Direito, podem ser questionáveis na maioria das vezes, ou pela sua consistência lógica ou pela obediência a regras preestabelecidas que permitam a dedução, e pelas duas anteriores.

A decisão, no seu âmago, é uma escolha, uma manifestação de Poder que possui gradações de influência diversas de acordo com limites objetivos e subjetivos inerentes a quem decide.

A influência pode estar limitada apenas àquele que decidiu ou pode abranger um grande número de pessoas. A escolha de um argumento em detrimento do outro; da aprovação ou reprovação de uma tese; e da aplicação ou não de determinada lei. E está escolha é subjetiva, por mais que se argumente ser o ordenamento jurídico norteador de toda e qualquer decisão. Em certos aspectos, é tão subjetiva quanto o “gostar” e, neste sentido, íntima a quem julga, estando próxima ao paladar e o olfato ${ }^{24}$.

\footnotetext{
${ }^{24}$ Neste sentido ver Hanna Arendt, The life of the mind, pp.254-272.
} 
O intuito da argumentação é o de persuadir, de levar o Julgador a "tomar gosto” e escolher, levando-o à decisão favorável no âmbito de uma determinada situação específica e particular. Apesar de esta situação estar adstrita, ela poderá influenciar outras situações particulares, mas somente por escolha (decisão) daquele do mesmo ou de outro Julgador, a despeito de o legislador buscar a convergência das decisões.

A convergência das decisões é uma necessidade. São vários os Julgadores, mas o Poder judicante, a competência para julgar, origina de uma única fonte: o Estado.

Estado e Poder não estão sujeitos a subjetividades, preferências ou idiossincrasias pessoais, pois são ficções. A ficção não tem gosto, não tem subjetividade. Logo, não seria coerente admitir que, perante situações idênticas ou semelhantes, há espaço para divergências. O “gosto” do Julgador não deveria sobreporse ao Estado, embora isto não se verifique na prática.

Dito de outra forma, aquele que recebe e exerce o Poder não deveria sobrepor-se àquele de quem o Poder originou, ao contrário, deveria possuir o mesmo sentido e direção, variando, apenas, na intensidade.

Se, com relação à conclusão, a rigidez e o formalismo do raciocínio analítico e da racionalidade podem repelir contrariedades e contradições, não se pode dizer o mesmo quanto à decisão.

A decisão admite a influência de fatores externos que farão parte do desenvolvimento argumentativo das premissas que comporão os silogismos, permitindo, inclusive, o estabelecimento de pontos de partida para a sua criação e a estipulação de condições e restrições conforme o caso em análise.

Na decisão, os pontos de partida serão determinados por um processo de seleção das normas que serão aplicadas, dos fatos e das provas integrantes do conjunto probatório e das teorias e das decisões anteriores que com elas corroborarão. 
Este processo é influenciado e guiado por características e aspectos subjetivos inerentes a quem decidirá, conforme dito acima, mas o que não se disse é que este mesmo processo sofre por influências inerentemente metafísicas que se equiparam a “eureca” ou a um palpite (hunch). A influência do palpite na decisão judicial é defendida por Joseph Hutcheson Jr, conforme apresentado mais adiante.

Apesar de o autor escrever sobre sua experiência nos tribunais da common law, não seria absurdo admitir que os Julgadores em geral seguem seus palpites, sua intuição por assim dizer, da mesma forma que os advogados e os cientistas.

Segundo ele, "and not only do I set down boldly that I, 'even as your other worships do,' invoke and employ hunches in decisions, but I do affirm, and will presently show, that it is that tiptoe faculty of the mind which can feel and follow a hunch which makes not only the best gamblers, the best detectives, the best lawyers, the best judges, the materials of whose trades are the most chancey because most human, and the results of whose activities are for the same cause the most subject to uncertainty and the best attained by approximation, but it is that same faculty which has guided and will continue to guide the great scientists of the world, and even those august dealers in certitude, the mathematicians themselves, to their most difficult solutions, which have opened and will continue to open hidden doors; which have widened and will ever widen man's horizon”, Hutcheson Jr. (1998:894-895).

Aproveitando o "gancho" do autor anterior, da mesma forma que no Direito poderia ser admitida a presença do hunch como ponto de partida para o processo decisório, na Economia a matemática teria a função de intuition pump para alguns economistas, conforme afirma Paul Krugman.

"What is true, however, is that many economists use mathematics not merely as a way to check the internal consistency of their ideas, but as an intuition pump'; they start with a vaguely formulated Idea, try to build a model that conveys that Idea, and allow the developing model in turn to alter their intuitions”, Krugman (1998:1833). 
A função do hunch e da matemática seriam as mesmas: determinar o ponto de partida e permitir a construção argumentativa, mas, na Economia, a própria matemática, para aqueles mais adeptos ao formalismo, serviria de argumento retórico e como uma forma de segregar a audiência entre os pertencentes da chamada main stream economics e outros adeptos aos demais ramos da Economia.

Não é demérito algum reconhecer a existência ou a possibilidade de os raciocínios (jurídico e econômico) terem início em algo que pode ser considerado menos nobre para os formalistas e mais tradicionais. O problema que se põe é como verificar a consistência da argumentação quando os recursos nela utilizados são empregados menos formalmente, de modo a amoldar-se a situações particulares.

Existe uma falsa percepção de que o Direito seria mais formal do que a Economia, pois está limitado a dogmas positivados de observância obrigatória, os quais colocariam limites ao raciocínio. Por outro lado, poder-se-ia dizer que a Economia, especialmente quando calcada no emprego da matemática no raciocínio, seria mais formal do que o Direito, vez que a matemática não admite inconsistências.

Direito e Economia são formais dentro dos limites impostos a cada um deles e dos instrumentos que podem ser utilizados na elaboração de sues raciocínios. Tanto no Direito quanto na Economia a consistência da argumentação empregada no raciocínio é uma necessidade; e esta consistência deve ser analisada do ponto de vista de suas características internas, independentemente de ser o ponto final a conclusão ou a decisão. É nesta hora que se questiona a aplicação do método-hipotético dedutivo no Direito.

A opinião de John Bell vai neste mesmo sentido. "Even if one can draw from the logic of legal reasoning and from the social practice of the legal profession a place for the notion of canons of acceptable arguments, it remains to be seen how far this is able to provide an adequate explanation of the limits on legal arguments. Once the simple deductive model of legal reasoning has been abandoned and the true place of value-judgments in the characterization of facts and the interpretation of rules is appreciated, then an explanation has to be provided of how the decisions reached are not 
just at the whim of the decision-maker and his idiosyncratic perceptions of what is right”, Bell (1986:59-60).

A impossibilidade (ou o abandono) do método dedutivo no Direito pode ter mais de uma explicação. Talvez, a mais contundente é que não há certeza de Direito, pois não há verdades e sim probabilidade e crença. Inclusive estas (probabilidade e crença) estão sujeitas ao arbítrio do Julgador que impõe pelo Poder coativamente sua opinião e vontade e, conseqüentemente, a sua decisão. Nem mesmo a decisão pode ser considerada uma verdade, mas sim um comando que produzirá efeitos na medida em que produzirem alterações nos seus destinatários.

Para permitir sua comparação com os dogmas do Direito constituídos pelas normas positivadas, poder-se-ia dizer que nas ciências ditas “duras”, como a Física, certas leis tenderiam a se aproximar da "verdade" devido ao seu desenvolvimento e constante questionamento e refutação. Seriam, assim, quase-dogmas, ainda que temporários (ou mesmo precários) de amplo reconhecimento por um determinado grupo de pessoas.

Nas normas positivadas, ao contrário do que ocorre na natureza, apesar de existirem dogmas de eficácia contínua ${ }^{25}$ não há nem de perto certeza. As normas são interpretadas e sua probabilidade de incidência pode ser afastada argumentativamente. Algo como se a Lei da Gravidade pudesse ser aplicada apenas aos corpos vermelhos em queda, mas não aos corpos azuis. Por outro lado, há certeza de decisão, e está é uma exigência do Direito.

Apesar de a decisão ser uma certeza, o Direito não o é. Max Weber já havia apontado o caráter probabilístico do Direito e o seu apoio na crença individual. "Uma ordem é denominada (...) direito, quando está garantida externamente pela probabilidade de coação (física ou psíquica) exercida por um determinado quadro de pessoas cuja função específica consiste em forçar a observação dessa ordem ou castigar sua violação”, Weber (2004, v.1, p.21).

\footnotetext{
${ }^{25}$ A eficácia contínua somente seria possível de ser concebida abstratamente. Seria equivalente ao movimento contínuo e perpétuo.
} 
Em outra passagem, “A forma de legitimidade hoje mais corrente é a crença na legalidade: a submissão a estatutos estabelecidos pelo procedimento habitual e formalmente correto", Weber (2004, v1:23).

A crença pode ser entendida como uma opinião particular resultante tanto da persuasão quanto da convicção. É tomar algo como verdade, ainda que temporariamente. Pode ser reduzida à probabilidade; a esperança de que algo ocorrerá ou deveria ocorrer.

Por exemplo, o crédito é uma crença. A crença de que se receberá de volta o que foi emprestado, caso contrário não se emprestaria. A garantia funciona como reforço desta crença na hipótese de o julgamento de quem empresta estar errado. Mesmo o exercício da garantia depende da crença de que o Julgador acatará os argumentos apresentados.

Em outros termos, só se empresta se a probabilidade de restituição for maior do que a probabilidade de não ser restituído o emprestado, quer pela boa vontade $^{26}$ daquele que recebeu, quer pela probabilidade de decisão judicial favorável a respeito da garantia.

Com o ordenamento jurídico ocorre o mesmo. Enquanto o indivíduo acreditar que a probabilidade de sanção for superior, tenderá a não agir fora dos limites da legalidade, salvo se o incentivo para fazê-lo for superior.

Portanto, nos dois casos a decisão está indissociavelmente atrelada à noção de probabilidade subjetiva. O indivíduo decide acreditando que está dentro da lei; o Julgador decide acreditando que está de acordo com o Direito, fazendo Direito ou atribuindo Justiça.

\footnotetext{
${ }^{26}$ Prefere-se assumir que o a restituição decorre da boa-vontade e não de uma obrigação moral ou legal. Isto porque há muito se debate sobre a proximidade entre o Direito e a moral, e entende-se que por mais que ambos sejam construções humanas e a moral possa interferir ao longo do processo de nomogênese jurídica, não há como defender esta vinculação sem discutir a relativização da moral e a sua problemática. Com relação a ser uma obrigação legal, esta somente pode ser considerada se admitida a inafastabilidade da ficção jurídica positivada na presunção absoluta da impossibilidade de alegação de desconhecimento do ordenamento jurídico. Mesmo esta ficção pode ser relativizada tendo em vista o padrão do homemmédio, ou de outro termo que busca ser uma ficção de indivíduo para avaliar condutas.
} 


\subsection{Os diferentes tipos de racionalidade jurídica.}

Conforme dito anteriormente, a racionalidade é inerente a uma entidade abstrata, ao contrário do raciocínio. Ela serviria para auxiliar na resolução de problemas que, apesar de se apresentarem na sua maioria no mundo real, requerem simplificação e abstração.

Neste sentido, a racionalidade deve ser vista de acordo com o correspondente fictício daquele que tomará a decisão, cujos efeitos serão sentidos no mundo real. Da mesma forma deve ser adequada ao problema que se busca resolver.

Assim, parte-se do pressuposto que, tal como Gunther Teubner (2005:233-268) defendeu, não é possível adotar indistintamente um único tipo de racionalidade para todos os ramos do Direito, sobretudo se considerada a sociedade globalizada onde o pluralismo desafia o monismo jurídico com formas mais flexíveis e ágeis de produção normativa.

Concorda-se com esta opinião, e vai-se além. Não basta defender a possibilidade de diferentes racionalidades. Antes disto é necessário determinar qual será o indivíduo que fará uso de cada uma destas racionalidades.

Vincular um tipo de racionalidade a um modelo de indivíduo é uma etapa importante. Tendo em vista a possibilidade de existência de diferentes racionalidades, conforme afirmado pelo autor alemão e com a qual concorda-se, não poderia ser defendida a existência de um único modelo de indivíduo que pudesse ser empregado no Direito, considerando-o com um todo, sem considerar as particularidades de cada um de seus ramos.

Para o que interessa no momento, não seria absurdo assumir que no Direito Pátrio estariam presentes elementos suficientes para construir ao menos um modelo de indivíduo - o qual permitiria a criação de uma entidade abstrata.

Sua função seria fazer às vezes de personagem central àquela disciplina do conhecimento humano (ou um de seus ramos ou vertentes), a qual seria utilizada no 
âmbito de uma ou de várias metodologias aplicáveis e com estas compatíveis e, por conseguinte, seria central à racionalidade que destas resultaria.

Estes elementos não estão na sua totalidade expressos e aparentes no ordenamento jurídico, na jurisprudência e na doutrina. Muitos deles se encontrem difusos ou são obtidos por raciocínio. Mas antes de prosseguir é necessário voltar um passo e identificar os diferentes agentes que podem ser encontrado no Direito.

No Direito defende-se que podem ser encontrados quatro agentes diferentes, cada um possui funções bem definidas e diferentes dos demais. Conseqüentemente, no mundo real e no mundo abstrato possuem, respectivamente, raciocínios e racionalidades distintas. Os quatro agentes são: legislador, Julgador, indivíduo e, por último o advogado. São agentes, pois suas ações seriam sentidas no mundo real.

Conforme alertado anteriormente, a racionalidade pressupõe o domínio puro da razão e conseqüentemente a criação de um modelo de indivíduo que guarde em alguma proporção correspondência com o que seria seu equivalente no mundo real.

Assim, reconhecendo-se a possibilidade de construção dos modelos correspondentes, possuiriam cada um deles, respectivamente, as seguintes racionalidades: racionalidade jurídica-legislativa, racionalidade jurídica-jurisprudencial, racionalidade jurídica-individual, e racionalidade jurídica-advocatícia.

Na doutrina é possível encontrar três dos quatro modelos necessários, cada um possuindo ao menos um modelo de indivíduo distinto. Para o primeiro, encontra-se o Legislador Racional, cujas propriedades foram sistematizadas por Carlos Santiago Nino, e o aproximam de uma divindade ocidental. Sabe-se que as propriedades do Legislador Racional têm sido questionadas e não são de fácil aceitação.

Tais propriedades são necessárias metodologicamente para se presumir a inexistência de contradições no ordenamento jurídico. Resumidamente, o Legislador Racional tem por propriedades ser singular, permanente, único, consciente, finalista, 
omnisciente, omnipotente, justo, coerente, omnicompreensivo, econômico, operativo e preciso, Ferraz Jr. (2003:280-281).

Para o segundo, o Juiz Hércules ${ }^{27}$, que parte de uma crítica feita por Ronald Dworkin. Para o terceiro, ainda que não se concorde com a construção feita pela doutrina, podem ser encontrados, por conta da incerteza terminológica presente no discurso jurídico, conforme já apresentado, o homem diligente, homem diligente e probo, homem prudente e diligente, homem razoável, homem avisado homem-médio e o (bonus) pater familias.

Não seria demais relembrar que, dependendo do papel desempenhado, a conduta que se esperaria do indivíduo será distinta. Por exemplo, a conduta esperada do autor não será a mesma do réu, apesar de as duas condutas serem direcionadas por princípios processuais que devem ser observados por ambos.

Apesar destas nuances, todos os modelos de indivíduos podem ser substituídos por uma única terminologia: Homo juridicus. O seu ancestral, afirma-se, é o (bonus) pater familias. A persona, do tripé romano res, persona, actio.

Todas as demais terminologias são tentativas frustradas de se criar um padrão de pessoa, variável no tempo e no espaço, mas ajustável ao caso concreto com o propósito de avaliação de conduta.

No caso particular do Homo juridicus, poder-se-ia argumentar pela existência de elementos suficiente para defender a existência de ao menos três ${ }^{28}$ modelos de indivíduo, ou de Homo juridicus diferentes. Tipos (ou gêneros), por assim

\footnotetext{
${ }^{27}$ Elaborado como uma crítica, em duas obras RONALD DWORKIN delineia as características do Juiz Hércules. Na primeira, Levando os direitos a sério, p 165, "inventei um jurista de capacidade, sabedoria, paciência e sagacidade sobre-humanas, a quem chamarei de Hércules.” Na outra, O império do direito, p. 287, "um juiz imaginário, de capacidade e paciência sobre-humanas, que aceita o direito como integridade.” Não é desnecessário lembrar que o Juiz Hércules foi inventado, nas palavras do próprio autor, para o âmbito dos sistemas judiciário e legal norte-americanos e, portanto, está sujeito às particularidades daqueles sistemas.

${ }^{28}$ Outras teses poderiam ser criadas de acordo com o papel a ser desempenhado, em alguns casos representados em pólos opostos. Por exemplo, autor e réu; empregado e empregador; contribuinte; empresário; comerciante e assim por diante.
} 
dizer, de Homo juridicus. Uma para o Direito Civil, outra para o Direito Penal e a última para o Direito do Consumidor.

Estes três modelos possuem elementos comuns e outros, próprios, os quais são inerentes a cada um dos diferentes $\operatorname{ramos}^{29}$ do Direito Positivo Pátrio nos quais estão inseridas.

Seria possível reduzir o conjunto de elementos de cada modelo a um subconjunto de elementos comuns, compartilhados, na busca de um modelo único de indivíduo para todos os ramos do Direito Pátrio. A criação de um único Homo juridicus que teria aplicação em todos os ramos.

Todavia, ao se fazer isto não seriam levados em consideração aspectos únicos e inerentes a cada um e que ao mesmo tempo contribuem para diferenciar esses ramos do Direito. Decerto, se este caminho fosse escolhido seriam perdidos os aspectos individualizadores e as nuances inerentes que os demarcam e separaram.

Mesmo assim, afirmar pela presença de um modelo de indivíduo para todos os ramos do Direito Pátrio (ou para o Direito Positivo de qualquer outro país) ou de uma particular para cada um deles acarretaria em implicações metodológicas para o Direito Positivo como um todo.

Isso porque traria implicitamente consigo a pressuposição de que os produtores das normas jurídicas levariam em conta durante o processo de sua criação o modelo de indivíduo referente ao ramo no qual àquela matéria que está sendo tratada estaria inserida. Este processo de criação normativa obedeceria algum método.

Na falta de um modelo de indivíduo específica para um determinado ramo, seria utilizada em seu lugar uma genérica que abrangesse todas as características essenciais àquele ramo ou ao Direito Positivo visto como uma unidade.

\footnotetext{
${ }^{29}$ Um ramo do Direito, como o Direito do Consumidor, também pode ser entendido como sendo um ou micro-sistema, um pequeno mundo normativo autônomo (cujas normas podem, até mesmo, contrariar normas de sistemas mais abrangentes) para o qual podem ser identificados princípios gerais e lógica, ambos particulares para ele. O conceito de micro-sistema foi originariamente proposto por NATALINO IRTI na obra L'età della decodificazione.
} 
Todavia, não se pode afirmar pela existência de qualquer modelo de indivíduo em uso pelo Legislador. De fato, não se pode afirmar que o Legislador faça uso de algum modelo ou método. O mesmo pode ser dito modelo sobre o advogado, pois este é entendido como uma extensão do indivíduo, mas que com ele não se confunde, porém, como regra, indispensável à defesa de Direitos.

Voltando, o primeiro agente, o Legislador Racional, busca, de acordo com sua conveniência e oportunidade, regular a vida em sociedade reduzindo a entropia (a desordem, ou o grau de desinformação) por meio da edição de normas jurídicas. Estas normas conduziriam o sistema para a eficiência, conforme buscada pelos defensores da Análise Econômica do Direito.

Descreve de forma abstrata e ampla as situações, prescrevendo condutas, mas deixando de lado considerações específicas quanto ao indivíduo, e, conseqüentemente, sem trabalhar com um modelo de indivíduo.

Um motivo plausível para não fazer uso de um modelo de indivíduo é a necessidade de se manter correspondência entre a realidade (o ser) e o abstrato (deverse), permitindo que o Julgador crie (ou adapte) um modelo de indivíduo para cada caso concreto sob análise.

A implicação direta é a necessária adequação do indivíduo à norma e não a adequação da norma ao indivíduo, o que deixa espaço para a livre criação da correspondência entre o real e o abstrato pelo Julgador.

Com relação ao Julgador, a racionalidade jurídica-jurisprudencial está presente durante a solução de conflitos de interesses resultantes das interações entre os diversos agentes, e entre estes e o próprio Estado.

Não se pode, nem mesmo, dizer que a racionalidade jurídicajurisprudencial é única. Ressalta-se a divergência com relação ao desempenho da função judicante. Para a tradição mais liberal, deve-se apenas dizer o direito aplicável ao caso concreto sem inovar, aplicando o disposto no ordenamento jurídico. O ordenamento 
jurídico seria, por assim dizer, fonte redutora de assimetria de informações, aumentando a previsibilidade dos resultados.

Para aqueles que questionam essa tradição, deve-se considerar outros fatores, sem se restringir à letra da lei, aceitando influências extrapositivas e, por assim dizer, maior flexibilidade ao decidir. Em contrapartida, seriam aumentadas a assimetria e a imprevisibilidade.

São pressupostos de atuação diferentes que não admitem a utilização de uma única racionalidade jurídica-jurisprudencial, comportando subtipos conforme a visão adotada.

Tendo em vista o indivíduo, tradicionalmente o raciocínio jurídico é concebido para o intérprete, no caso o advogado ${ }^{30}$ representando seu cliente. Logo, não toma por padrão o ponto de vista do indivíduo - um dos destinatários do Direito juntamente com o Julgador. Isto porque o indivíduo é tradicionalmente visto como o titular de direitos e de deveres. Assim, a técnica jurídica empregada pelo advogado e pelo Julgador seria a mesma, o que não se pode conceber ao se falar de racionalidade.

Com relação ao indivíduo, pode-se dizer que o Direito visa regular o auto-interesse, estabelecendo limites para a sua manifestação e, ao mesmo tempo, obrigando a cooperação e a solidariedade, tal como pode ser verificado nos casos da omissão de socorro e da gestão de negócios.

Em tese, Legislador e Julgador, na qualidade de responsáveis pelo controle social, deveriam levar em conta, ao longo do processo de criação da norma jurídica (nomogênese jurídica), certas condutas que poderiam ser assumidas como possíveis de adoção por um dos diferentes modelos de indivíduo no agir individual como conseqüência das características a elas atribuídas.

\footnotetext{
${ }^{30} \mathrm{O}$ advogado antes de tudo é um indivíduo. Porém, ao exercer a função de defender os interesses de seu cliente, não se pode dizer que haja superposição entre ambos. São papéis distintos dentro da sociedade. Ao exercer seus direitos enquanto prestador de serviços jurídicos, o advogado não se confunde com o indivíduo. Em outros momentos, ao defender seus próprios direitos, seria o próprio indivíduo.
} 
Se, por um lado, teriam interesse em desestimular a adoção de certas condutas, por outro teriam interesse em estimular outras sinalizando, por intermédio das normas criadas, as suas preferências. Mas para fazer isso seria necessário determinar o modelo de indivíduo para a qual a norma está sendo produzida.

A despeito da dimensão moral e dos problemas que desta surgem, o Legislador Racional ao formular leis e o Julgador ao se deparar com uma situação de desestímulo poderia decidir tendo em vista, conforme propôs Oliver Wendell Holmes Jr., um bad man.

Nas palavras dele, "If you want to know the law and nothing else, you must look at it as a bad man, who cares only for the material consequences which such knowledge enables him to predict, not as a good one, who finds his reasons for conduct, whether inside the law or outside of it, in the vaguer sanctions of conscience”, Holmes Jr. (1897:459). O bad man guiaria suas ações tendo por objetivo o ganho (ou evitar a perda) material, não se preocupando em estar dentro ou fora da lei.

De forma parecida ao bad man, André Comte-Sponsville cunhou o termo “canalha legalista”. “De modo que nosso indivíduo perfeitamente legalista poderá, em plena conformidade com a legalidade republicana, ser mentiroso, egoísta, cheio de ódio e desprezo, numa palavra, mau. O que ele seria, então, senão um canalha legalista? (...) Ora, vocês hão de entender que não temos nada, nessa segunda ordem, para escapar do que chamarei de espectro do canalha legalista - já que ele se define pelo respeito completo, escrupuloso, intransigente de toda a legalidade”, Comte-Sponsville (2005:5455).

O canalha legalista seria um indivíduo que viveria de acordo com o Direito, adaptando suas ações conforme seus interesses sem, contudo, violá-lo. Dito, conforme o autor, ele mentirá, desprezará, terá ódio e agirá maldosamente sem, contudo, agir ilegalmente.

Rudolf Von Jhering anos antes chamou atenção para o direcionamento artificial do interesse alheio pelo indivíduo. “A própria natureza indicou ao homem o caminho que deve tomar para aliciar outrem para seus fins: trata-se da ligação do 
objetivo individual com o interesse alheio. Toda a nossa vida humana repousa sobre esta fórmula: o estado, a sociedade, o comércio e as relações. Uma cooperação de diversos homens, visando o mesmo fim, só se efetua na medida em que os interesses de todos convirjam para o mesmo ponto. (...) Onde a priori inexiste tal interesse, importa criá-lo artificialmente”, Jhering (2002, t.I:37).

Novamente, o direcionamento artificial do interesse alheio, se pautado pelo Direito, seria dificilmente alcançado pelo Julgador. Os três autores (Holmes, Comte-Sponsville e Jhering) apontam para a mesma direção. O interesse individual, ou o auto-interesse, faz parte do Direito e não há como alcançá-lo, sem incorrer no relativismo moral, se não houver ilegalidade.

A má-fé, vista como sendo a conseqüência da criação proposital de assimetria de informações entre as partes, seria uma das formas de surgimento da ilegalidade decorrente da manifestação excessiva do auto-interesse. Estando, conseqüentemente, no campo de visão do Julgador. O mesmo pode ser dito dos delitos patrimoniais, do abuso de direito, do açambarcamento e da formação de cartel, por exemplo.

Julgador e Legislador também têm interesse em estimular a adoção ou o mimetismo de certas características. Assim, o Direito estimularia a adoção de determinadas condutas, fornecendo incentivos, muito embora dependa do interesse individual para, de fato, se concretizar e ter o efeito pretendido. Esta outra faceta é mais simples de ser vista sob o aspecto econômico. O estabelecimento de empresas em determinada região e a movimentação de capitais do estrangeiro para o País exemplificam.

Tanto o desestímulo quanto o estímulo são inerentes ao controle social exercido por intermédio do Direito. Para admitir esta possibilidade de controle é necessário pressupor que o indivíduo seja capaz de, compreender o conteúdo da norma posta e ao menos, ordenar logicamente suas preferências.

Os seres humanos são dotados de razão, mesmo que esta não seja determinante na sua conduta. A razão permite o raciocínio e a compreensão do conteúdo 
da norma e por conta dela é que se exige a observância de determinada conduta prescrita. Mas nem sempre foi assim, como aponta Hans Kelsen.

"No Direito primitivo, os animais e mesmos as plantas e objetos inanimados são muitas vezes tratados da mesma maneira que os seres humanos e, particularmente, punidos. Contudo, o fato deve ser visto em sua conexão com o animismo do homem primitivo. Ele considera os animais, as plantas e os objetos inanimados como providos de uma 'alma', porquanto lhes atribui faculdades mentais humanas e, às vezes, sobre-humanas. A diferença fundamental entre o ser humano e os outros seres, que faz parte da perspectiva o homem civilizado, não existe para o homem primitivo. E ele aplica seu Direito também a seres não humanos porque, a seu ver, eles são humanos ou, pelo menos, similares ao homem. Neste sentido, o Direito primitivo também é uma ordem da conduta humana”, Kelsen (2000:6).

O Direito, nos tempos atuais, não apenas faz distinção entre os seres humanos e os animais, plantas e objetos inanimados. O Direito faz distinção entre os próprios seres humanos de acordo com a presença de razão ao adotar critérios como o biológico, o psicológico e o biopsicológico para determinar se o agente possui, ou possuía na ocasião do evento, capacidade de entender e/ou compreender as conseqüências resultantes de sua conduta e, com, isso afastar ou atenuar a culpa do agente.

Em outras situações, determina idade mínima para que o agente tenha a capacidade para a prática de determinados atos. Em outras palavras, a razão, apesar de ser um fato natural, uma característica que define e diferencia os seres humanos dos animais, somente terá conseqüências de acordo com os limites prescritos pelo Direito.

Aqueles que estiverem fora destes limites são afastados do convívio em sociedade; têm a sanção de suas condutas abrandadas ou até mesmo afastadas; não sofrem qualquer sanção; são impedidos de praticar determinados atos; e, ainda, quando praticam certos atos, estes não produzem efeitos.

Logo, a prescrição legal somente se aplica àqueles que a própria lei considera como sendo dotados de razão (em alguns casos, razão é entendida como 
consciência) suficiente para compreender as conseqüências da própria lei que as prescreveu. Assim, a decisão deve sempre emanar de uma pessoa dotada de razão.

A vida à margem da lei é, antes de ser um problema social, uma escolha que traz consigo uma preferência. Ninguém é obrigado a praticar ilegalidades, a roubar um banco ou a furtar um livro. Mas há casos em que a única opção é a adoção de uma conduta que pode ser tipificada como sendo ilegal. Trata-se de exceção.

O Direito não controla a sociedade pela exceção, e sim por aquilo que seria esperado em condições de normalidade. E dentro desta normalidade há que se encontrar a pressuposição de que o destinatário do Direito, na sua média, seja racional.

Uma nação composta na sua maioria por irracionais, loucos e insanos de todo o gênero é ingovernável, pois seus atos não são previsíveis e eles são incapazes de reconhecer a autoridade do Estado. Afinal, é do Estado que são emanadas as leis e para conhecê-las a razão é indispensável.

\subsection{Os diferentes tipos de decisão.}

A problemática acerca da decisão afeta os quatro tipos de decisão que podem ser encontradas no Direito. A legislativa, a do advogado, a individual, e a do Julgador. São decisões que não se confundem e seguem propósitos diferentes.

A decisão legislativa procura estabelecer o controle social por meio de um conjunto de normas. As normas emanadas do Poder do Estado são transformadas em fatos que refletem no ordenamento jurídico. Não se discute porque certa norma foi positivada ou determinada conduta foi escolhida pelo Legislador em detrimento de outras. Apenas reconhece-se a sua existência.

A decisão do indivíduo e a decisão do advogado não se confundem apesar de as duas refletirem na esfera jurídica do indivíduo. O ordenamento jurídico estipula como regra que o indivíduo deve ser representado por advogado para ser parte em processo, e, como exceção, o jus postulandi. 
O indivíduo representado por advogado ou exercendo o jus postulandi perante o Julgador, os dois (advogado e indivíduo) visam unicamente a vitória. Não seria racional buscar a derrota, salvo se a derrota fornecesse incentivos sob a forma de benefícios e, desta forma, seria racional. Para saírem vitoriosos construirão argumentativamente suas teses, podendo, inclusive, construir um modelo sobre o indivíduo que minimize os incômodos da aplicação do Direito.

E este modelo dificilmente corresponderá com o indivíduo propriamente dito, mas ressaltará ou incorporará as características necessárias. Logo, suas decisões, aos olhos do Julgador, são convergentes e têm por objetivo uma decisão favorável, ou seja, a minimização dos efeitos de uma possível condenação ${ }^{31}$.

Nesta situação a referência é feita a uma ação tomada pelo indivíduo no passado e que, por algum motivo, foi considerada afrontosa ao Direito durante o processo decisório que o levou à ação ou que decorreu da ação. Existia, pois, à época, a necessidade de antever as possíveis situações que poderiam se desdobrar da ação.

Por outro lado, em menor magnitude o advogado experimentará a mesma desvantagem que o Julgador. Existirá sempre, por mais que seja eficiente a comunicação entre indivíduo e advogado, assimetria de informações por conta do aspecto temporal e da seleção prévia, intencional ou não, feita pelo indivíduo das informações que serão transmitidas ao advogado.

Portanto, enquanto nos casos em que é permitido o jus postulandi haverá apenas uma situação de assimetria de informações (entre o indivíduo e o Julgador), nos casos em que é obrigatória a representação por advogado haverá dupla assimetria de informações, a primeira entre indivíduo e advogado, e a segunda entre advogado e Julgador.

As relações indivíduo-advogado, indivíduo-Julgador e advogadoJulgador serviram, apenas, para distinguir as situações que não são relevantes para o

\footnotetext{
${ }^{31}$ A vitória é a minimização, por excelência, dos efeitos de uma possível condenação. É a minimização por completo.
} 
momento, apesar de ter sido feita distinção superficial entre elas. Isto porque a decisão tomada é sempre tendo em vista a vitória perante o Julgador.

Passa-se, a partir de agora, a tratar dos dois outros tipos de decisão, os quais interessam ao presente trabalho. Neste caso, a separação entre a decisão do indivíduo e a decisão do Julgador é imperativa para, inicialmente, aclarar os diferentes momentos em que acontecem e quais são seus propósitos.

Conforme dito, a decisão perante o Julgador tem por objetivo a minimização de efeitos de uma possível condenação, sempre com relação a uma ação anterior tomada como conseqüência de uma decisão. O que interessa neste ponto é exatamente esta decisão, sempre vista do “eu” para o “outro”.

Do ponto de vista do indivíduo, enquanto este (o “eu”, ou o indivíduo A) deveria levar em conta o modelo do outro indivíduo (o “outro”, ou o indivíduo B) durante o processo que antecede a sua decisão, o Julgador constrói argumentativamente dois modelos de indivíduos, um sobre o indivíduo A e outro sobre o indivíduo B. Estes modelos servirão de premissas para justificar sua decisão depois da verificação das condutas adotadas em certa situação.

Enquanto as construções feitas pelo Julgador não são modelos de indivíduo, apenas aproximações da realidade tendo por base as provas carreadas ao processo, o modelo formulado pelo indivíduo A sobre o indivíduo B é um marcador de expectativas que determinaria a conduta que seria minimamente admissível pelo indivíduo A e esta não é obrigatoriamente compatível com o prescrito pelo Direito, ou seja, pelo Legislador.

A atuação do Julgador está em comparar a conduta dos indivíduos com a prescrita pelo Direito e com a expectativa de conduta de um em relação ao outro. A visão do Julgador está limitada ao que a ele é apresentado pelos dois indivíduos, quando deveria alcançar as expectativas à época. Tarefa reconhecidamente difícil de ser levada a cabo por conta da presença de assimetria de informações, vez que o Julgador está limitado ao que os dois indivíduos a ele apresentam e as suas próprias limitações subjetivas. Afinal, este não é o Julgador ficcional e está sujeito ao erro. 
O erro é uma falsa percepção da realidade, ou como disse Søren Kierkegaard, “(...) o erro consiste em não compreendermos correctamente o enunciado (...)”, Kierkegaard (2007:10).

A forma encontrada para escapar da possibilidade de erro é por meio da criação de entidades ficcionais, abstraídas da realidade e dotá-las de racionalidade, deixando o raciocínio para os seres de carne e osso estes, falíveis.

Para reduzir a chance de erro e, ainda, fornecer um marcador comparativo, a conduta prescrita pelo Direito deveria levar em conta um modelo de indivíduo consistente para determinado ramo do Direito ou, no limite, para todos os seus ramos. Atualmente, na ausência deste marcador, fica cada Julgador incumbido de criar um modelo de indivíduo para o caso concreto.

Indivíduo e Julgador empregam o raciocínio jurídico para decidir, não há debate sobre isto, mas com propósitos diferentes e a decisão é tomada em momentos distintos e com informações desiguais.

Num processo judicial, as partes, com exceção nos casos de hipossuficiência, possuem acesso igual à jurisprudência e à doutrina. Podem contratar especialistas para assessorá-las. A diferença está apenas na qualidade dos serviços, a qual se reflete nos preços praticados estando limitada, conseqüentemente, pelo orçamento disponível para o litígio. Pode-se dizer que, com relação a estas informações, o Julgador, por seu turno, está em pé de igualdade com as partes, com os indivíduos.

Invariavelmente é construído um modelo de indivíduo com o objetivo de ressaltar certa conduta, ampliando a diferença entre a conduta prescrita e a conduta efetivamente verificada. Ao se fazer isso, o comportamento inicialmente antecipado sofre um processo de degradação ou de majoração para aumentar, no primeiro, e reduzir, no segundo, seus efeitos.

Porém, com relação à verdade sobre o fato em si dificilmente ela será de conhecimento do Julgador. Isto porque as partes somente trazem ao conhecimento do 
Julgador e da outra parte aquilo que a interessa, não prejudique e que corrobore com a tese formulada.

Conseqüentemente, além da verdade propriamente dita, há a possibilidade de construção de mais três, por assim dizer, outras verdades. A de uma parte, a da outra, e a do Julgador, que pode ser diferente de todas as outras três, pois estar adstrito aos pedidos formulados não significa corroborar com a tese defendida.

O conflito se resume, então, na assimetria de informações. Aquela parte que estiver em desvantagem com relação ao acesso às informações, terá menores chances de sucesso no litígio. O que abre espaço para a seguinte pergunta: como entender a boa-fé e a lealdade processual se não há como garantir a todas as partes e ao Julgador igualdade no conhecimento dos fatos?

A solução adotada pelo Direito está na criação de um mundo ficcional e paralelo ao mundo real muito mais restrito e pobre se comparado com a realidade. Um mundo processual com data de início e com certeza quanto ao seu término, onde os fatos e as provas trazidas pelas partes são os únicos que realmente têm importância. Ao fazer isto, o Direito possibilita a redução da assimetria.

A decisão do indivíduo é anterior ao envolvimento do Julgador. Ela envolve um número maior de informações, fatos e situações, sendo sempre contemporânea a estes, e seus efeitos se prolongam no sentido do tempo, ou seja, do presente para o futuro. Além disso, parte de uma presunção de conduta a ser adotada futuramente pelo outro.

A decisão do Julgador, por sua vez, não é contemporânea as informações, fatos e situações. Ela é tomada no futuro (quando não possui intuito preventivo), e busca analisar o passado, com o propósito de reparar ou confirmar seus efeitos. Segue sentido contrário ao do tempo, indo do futuro para o passado. Uma de suas tarefas é verificar a distância entre a conduta esperada e a conduta prescrita.

São dois pontos de vista temporais que evidenciam a diferença entre os tipos de decisão. Por conta disso, a decisão do Julgador será sempre mais precária do 
que a do indivíduo se for considerado unicamente o ponto de vista dos elementos disponíveis para a decisão. Obrigatoriamente o Julgador deverá fazer considerações quanto à conduta esperada.

O Julgador está livre para decidir desde que justifique (motive) a sua decisão. Ele pode valorar o que inclui descartar (ou desconsiderar) provas, selecionar o Direito aplicável ao caso, buscar subsídios na jurisprudência, enfim, selecionar os argumentos necessários que suportarão sua decisão.

Mas em que momento ele valora, seleciona e busca subsídios? Depois de decidir. Não há alternativa se a decisão tiver que delas decorrer logicamente. A pressuposição é que a decisão já está tomada pelo Julgador e o processo cognitivo que a antecede já foi finalizado. Dito de outra forma, ele primeiro decide e depois motiva (justifica) sua decisão. E, neste processo, constrói seu modelo de indivíduo, começando pela conduta.

O enfoque do Julgador contraria aquilo que se esperaria, ou pelo menos está na contramão do que pode ser visto na Economia ${ }^{32}$, onde o método hipotéticodedutivo é aplicado. No Direito é marcante a decisão e esta é a priori. Desenvolvimento e premissas a posteriori, nesta seqüencia.

Como admitir que o Julgador seguirá o caminho iniciado pela determinação das premissas, desenvolvimento, e, apenas por último, a conclusão? Poderia, inclusive, não haver decisão o que não é admissível no ordenamento jurídico pela vedação ao non liquet ou decidir contra legem, sabendo que sua decisão correrá o risco de ser questionada e reformada.

As teses desenvolvidas para amparar a racionalidade na decisão pelo órgão judicante vão neste sentido. Antônio Castanheira Neves aponta três tipos distintos de racionalidade jurídica. Teorética (normativo-dogmática e empírica), Tecnológicosocial, e Prático-jurisprudencial, Castanheira Neves (1993:49-81).

\footnotetext{
${ }^{32}$ Se a Economia é ou não ciência, não faz parte da discussão. Para isto seria necessário, primeiro, definir o que é ciência e quais os requisitos para considerar ciência uma determinada disciplina do conhecimento humano.
} 
Tércio Sampaio Ferraz Jr. dedica um capítulo inteiro de seu livro ${ }^{33}$ a dogmática da decisão. Entretanto, não há teoria que resista quando a decisão possuir grande repercussão social ou política. Por mais que o juiz esteja adstrito à lei e seja obrigado a decidir.

As teses sobre a decisão do Julgador que são encontráveis na doutrina não são poucas, mas este trabalho não visa fazer uma revisão ou análise das obras de metodologia jurídica ou de lógica jurídica.

Fato é a grande importância dada pela doutrina à decisão pelo Julgador e à função jurisdicional. Isto porque a decisão judicial é uma resposta necessária a sociedade, pois sem ela o cidadão não se sentirá amparado e coloca-se em risco o controle social pela autoridade, restando unicamente à força. O que colocaria em risco os Princípios que suportam o Estado de Direito.

O Julgador deve decidir em todos os casos concretos como se tivesse conhecimento da totalidade das normas existentes no ordenamento jurídico, mas não só isso. Deve conhecer os costumes, princípios gerais do direito e, ainda, ser capaz de identificar semelhanças para poder aplicar o raciocínio por analogia.

Como se não bastasse, precisa decidir em conformidade com a jurisprudência vigente de modo que as decisões sejam convergentes sempre que possível. Em suma, deve ser onisciente em relação ao ordenamento jurídico e à sociedade. Trata-se de uma onisciência obrigatória, um “dever-se”.

Críticas são freqüentemente direcionadas à concepção de juiz, por conta de seus necessários poderes sobre-humanos. O Juiz Hércules, de Ronald Dworkin é, possivelmente, a caricatura mais conhecida, e pode ser estendida da common law para o sistema Romano-Germânico.

\footnotetext{
${ }^{33}$ Capítulo 6 do livro Introdução ao estudo do direito: técnica, decisão, dominação.
} 
O fenômeno do poder é indissociável do Direito, não há dúvida, mas será que a única decisão que de fato importa é a de quem tem poder para impor coercitivamente uma decisão? Dificilmente.

Por mais crítico que se possa ser, não se ignora a importância dada pela doutrina à decisão judicial e a necessidade de atribuir características irrealistas ao julgador com o intuito de obrigar a decisão. Apenas se advoga pelo indivíduo.

Entende-se que uma empresa, ou qualquer outra coletividade de indivíduos estabelecida por um negócio jurídico, pode, da mesma forma que a sociedade, ser reduzida a sua unidade mais básica: o indivíduo. Não há empresa sem uma pluralidade de indivíduos (com exceção das sociedades unipessoais), nem sociedade. A parte vem antes do todo.

A decisão é sempre do indivíduo. Uma decisão colegiada seguirá o somatório das decisões individuais. Uma eleição segue a mesma sistemática.

Da mesma forma que o julgador, o indivíduo também justifica sua decisão, mas em momento distinto. Veja-se, por exemplo, o caso de uma empresa que possui duas alternativas de investimento. A primeira, mais segura, mas cujos retornos são inferiores. A segunda, ao contrário, possui retornos maiores, mas existe o risco de o resultado deste investimento ser considerado uma infração à lei.

O que a empresa fará? Contratará serviços de bons profissionais, como contadores, advogados, especialistas na área, e de posse da opinião de todos avaliará as duas alternativas levando em consideração os riscos existentes. Somente depois de ponderar, decidirá sobre o que fazer.

Nesta situação, o Direito, juntamente com as demais informações recebidas, exerce o papel de mais uma informação à decisão, mas não para justificar a decisão. A principal motivação, a justificativa por assim dizer, será econômicofinanceira. 
Continuando, feito o investimento na segunda alternativa, ocorre o questionamento de sua legalidade, conforme antevisto. A empresa apresentará sua defesa, argumentando juridicamente com o intuito de justificar sua decisão, discorrendo sobre a inexistência de ilícito. Não poupará esforços nem recursos para fornecer informações que possam influenciar o julgador, tornando-o simpático ao seu ponto de vista. Esgotadas todas as vias e se condenada for, ainda fará de tudo para minimizar os efeitos da sanção a ela atribuída.

Não se nega a característica argumentativa do Direito, onde impera o juízo qualitativo. Mas será que esta tradição do Direito não ofuscou aspectos mais importantes da metodologia e, por conseguinte, da racionalidade? A racionalidade não deve ser centrada no Julgador, e sim o raciocínio, fazer isto é considerar apenas um dos destinatários do Direito, subjugando o outro, o indivíduo em si.

Decidir é escolher, não necessariamente agir. Todos podem exercer dentro de suas esferas jurídicas este poder individual. Ele é inerente ao ser humano e está diretamente relacionado com o exercício livre da autonomia, do livre arbítrio.

Os conflitos de interesse surgem por diversos motivos. E seu destino final é o Judiciário. Não raro, atribui-se o aumento do número de conflitos à ampliação do acesso ao Judiciário, em especial pelas camadas mais baixas da sociedade.

A sociedade avança e as leis são adequadas, ajustadas, à nova realidade social pela hermenêutica. Algumas são ultrapassadas e caem em desuso, passando a ser letras mortas, mas nem por isso deixam de ser Direito. Quando não eivadas de vícios, elas ficam aguardando o Legislador jogar uma pá de cal no sepultamento conduzido pelo avanço social, revogando-a ou derrogando-a.

Pouco se fala da inadequação das leis ao indivíduo, apenas da adequação do indivíduo às leis - trabalho realizado pela hermenêutica e pela argumentação jurídicas - e para isso são usados modelos históricos de comportamento individual.

Mulher honesta, bonus pater familias, são expressões que remontam a uma sociedade onde a mulher de Cesar devia não apenas ser honesta, mas também 
parecer honesta. Como se honestidade fosse tão abundante nos dias de hoje que não é mais necessário estabelecer este padrão, ou atualmente é um conceito tão vago, aberto, que comporta diversos níveis e padrões de honestidade.

O Legislador sepultou a mulher honesta, mas a doutrina perpetua o bonus pater familias, despótico, senhor de escravos, soberano, capaz de regular, julgar e executar. Há um descompasso. Como exigir de um homem da atualidade este comportamento? "Senhor juiz, ele puniu sua empregada doméstica com cinqüenta chibatadas, é um pater familias completo, por qual motivo foi condenado?”

Como estender à mulher, que exerce o mesmo papel social do homem na atualidade, o conceito de bonus pater famílias? Afinal, a raiz histórica se encontra numa sociedade patriarcal, onde a mulher deveria cuidar dos jardins e embelezar a sala. A mulher da atualidade encontra-se desamparada de um padrão de conduta, como cobrá-la juridicamente?

Esta prática - de buscar adequar o indivíduo à lei - ofusca um problema metodológico que poderia ser contornado (ou mitigado) se uma pequena parte dos esforços empregados em formular teorias sobre a decisão do Julgador e fosse aplicada na fonte das controvérsias: no indivíduo.

Mas o que dizer sobre o ponto de vista do indivíduo, como ele decide?A resposta a esta pergunta não é tão complexa, basta uma análise interior. Decide levando em conta o tempo, o custo, o resultado, a moral, combinações destes ou vários outros. Variadas serão as respostas, podendo classificá-las entre quantitativas e qualitativas. Todas são respostas possíveis, mas quanto maior a diversidade de pessoas, maior o número de respostas.

Se todas as respostas fossem padronizadas e colocadas para os indivíduos escolherem, tendo em vista indivíduos com as mesmas características, possivelmente em algum ponto haveria maior concentração, denotando algum tipo de convergência.

Mesmo as respostas de cunho predominantemente qualitativo e relativista podem ser analisadas numericamente. Ao menos três grandes economistas defendem 
esta posição. São eles: Thomas Robert Malthus, William Stanley Jevons e Oskar Morgenstern.

Para o primeiro, "many of the questions, both in morals and politics, seem to be of the nature of the problems de maximis et minimis in Fluxions; in which there is always a point where a certain effect is the greatest, while on either side of this point it gradually diminishes", Malthus (1814:30).

Para o segundo, "It is clear that Economies, if it is to be a science at all, must be a mathematical science. There exists much prejudice against attempts to introduce the methods and language of mathematics into any branch of the moral sciences. Many persons seem to think that the physical sciences form the proper sphere of mathematical method, and that the moral sciences demand some other method, - I know not of what”, Jevons (1888:3).

Para o terceiro, "to eliminate some apparent obstacles to the uses of mathematics which are still frequently mentioned, I shall state a few properties of mathematics by implication: There is no limitation because economics deals with psychological entities, sometimes with non-quantitative data, with expectations, or with mixtures of qualitative and quantitative entities in the same argument. Mathematics is not a science of quantities only; it does not require measurement, there is no fundamental difference between a simple addition with integers and that expressed by an integral. Mathematics does not necessarily need symbols other than words which, up to some degree of complication, can adequately express mathematical ideas, state theorems, formulate proofs. Mathematics is not only a deductive science, it also uses (logical) induction for proof”, Morgenstern (1963:3).

Os três autores acima reconhecem o utilitarismo de Bentham o mesmo autor que impulsionou o movimento de codificação na Europa e resultou no Código Francês, cuja influência no Código Civil de 1916 é marcante.

O citado Código Francês é resultante do movimento de codificação que surgiu no continente europeu. Ele não foi o primeiro código surgido, pois na segunda 
metade do século XVIII os códigos da Baviera (1756), Prússia (1792) e da Galícia (1797) já haviam sido publicados, mas foi, possivelmente, o mais influente.

Ao contrário do que se costuma pensar tradicionalmente na Economia, pode ser adotada uma opinião diferente, a que Bentham possuía forte inclinação intervencionista, contrariamente a visão de que suas idéias seriam unicamente liberais, como pode ser observado na New Poor Law de 1834.

As idéias de codificação de Bentham - palavra por ele criada - também não fogem a essa visão. O código pode ser visto como manifestação do Poder estatal na sociedade, impondo um conjunto normativo e exaustivo de comandos legais e normas de interpretação de conhecimento público e em linguagem acessível com o propósito de evitar (ou reduzir) a ignorância das pessoas e, com isto, direcionar as ações permitindo assumir certa previsibilidade de conduta.

Deste ponto em diante, assume-se que as questões de ordem moral podem ser analisadas objetivamente, da mesma forma que os primeiros economistas fizeram.

Decorre, assim, que a moral pode ser transformada em um valor numérico, da mesma forma como que os médicos modernamente fazem para graduar a dor por meio de escalas numéricas hierarquizadas, permitindo sua avaliação quantitativa. Ao fazer isso, atribui-se a um critério subjetivo (como o gosto ou a dor), uma escala objetiva. Permitindo, assim, calcular o máximo de bem-estar. 


\section{CAPÍTULO 3: A TEORIA DE KARL POPPER COMO EXPLICAÇÃO E DEMARCAÇÃO.}

Nos capítulos anteriores procurou-se argumentar sobre a ausência de um modelo de indivíduo no Direito, apesar de o próprio Legislador traçar determinadas características que dele seriam esperadas, e a doutrina criar ficções, ora como crítica, ora para auxiliar na hermenêutica.

Tendo por premissa a falta de um modelo de indivíduo e considerando que o Direito além de ser uma Ciência Humana é também uma instituição social cuja função é direcionar as ações sociais, buscou-se na literatura teoria que pudesse levar em consideração todos estes aspectos.

Karl Popper desenvolveu duas teorias que podem auxiliar na demarcação e na redução do autismo do qual sofre o Homo oeconomicus, permitindo trazer outras informações ${ }^{34}$ - além dos preços - como o ordenamento jurídico, os costumes, a jurisprudência e os princípios gerais de Direito, para a decisão que antecede sua ação.

Ao se fazer isto, Homo oeconomicus e Homo juridicus estariam em pé de igualdade, o que possibilitaria o uso do primeiro como ferramenta metodológica no âmbito do Direito.

Estas teorias - a Lógica Situacional e a Teoria dos Três Mundos - são compatíveis entre si, não requerendo nenhum esforço adicional para trabalhá-las em conjunto.

Mas antes de chegar até elas, é necessário percorrer um caminho teórico que permitirá compreender a sua função.

\footnotetext{
34 Somente será considerada informação se houver alteração na percepção de um determinado estado da natureza, fato ou situação.
} 
Até o momento não foi utilizado o termo “ontologia” ou "tese ontológica”, salvo na Introdução do trabalho. Preferiu-se, conforme indicado previamente, utilizar em o temo "modelo de indivíduo”.

Para seguir adiante é necessário, daqui até a Conclusão, que está próxima, incluir os termos corretos.

\subsection{Uma ontologia do indivíduo.}

Discorrer sobre a necessidade de uma tese ontológica para o Direito com o propósito de criar uma entidade abstrata com correspondência a uma entidade concreta é, também, discorrer sobre o plano de sua existência e de suas características. É discorrer sobre o “ser” que está sob análise.

Émile Durkheim e Max Weber tinham traçado os contornos de uma entidade abstrata, cujas características de seu "ser” seriam atribuídas pelo cientista.

Menos sistematicamente foi o que fez Pareto ao justificar a utilização do Homo oeconomicus de Pantaleoni. Afinal, as características deste modelo de indivíduo eram isoladas numa entidade abstrata, tornando-a pura, tal como o oxigênio o enxofre na tabela periódica de elementos.

Muito se debate na Filosofia sobre os conceitos metafísicos de existência e realidade. Neste sentido Popper com a Teoria dos Três Mundos fornece uma abordagem adequada, mas não a única.

\subsection{O que seria um tipo-ideal?}

O tipo-ideal é uma ficção criada pelo cientista que serve de recurso metodológico para investigar e expor fenômenos que podem ser encontrados na sociedade, permitindo a sua mensuração. Por se tratar de uma ficção, amolda-se a necessidade do cientista.

Para criar o tipo-ideal ele seleciona os aspectos relevantes dos papeis sociais que os seres humanos desempenham na vida real. Ele delimita os limites objetivos de sua análise ao abstrair do contexto social e isolar os aspectos relevantes, 
dando-os o destaque necessário. Também é possível incorporar no tipo-ideal aspectos, comportamentos e características não observáveis nos seres humanos.

Apesar de uma possível relação de correspondência entre o real e a ficção, não há confusão entre ambas. O tipo-ideal não tem por propósito replicar a complexidade de sua contraparte na realidade, se fosse assim, perderia toda a vantagem decorrente da simplificação obtida com o seu uso.

Por se tratar de uma abstração, de uma construção, o tipo-ideal pode ser dotado de característica puramente lógicas, racionais, por assim dizer, mas sem, contudo, pretender lançar qualquer juízo de valor ao seu correspondente no mundo real.

O tipo-ideal também é necessário, pois empiricamente não é possível encontrar um tipo único e puro que possua e represente todas as características dos mais diversos seres humanos.

Isto porque, segundo Émile Durkheim, com a existência de “apenas uma única espécie social, as sociedades particulares não podem diferir entre si a não ser em graus, conforme apresentem mais ou menos completamente os traços constitutivos dessa espécie única, conforme *exprimam* mais ou menos perfeitamente a humanidade”, Durkheim (2007:79).

Além disto, conforme o mesmo autor, a criação de um número restrito de tipos e a substituição da multiplicidade indefinida de tipos abrevia o trabalho científico.

"Mas ainda que uma classificação fosse possível com base nesse método, ela teria o grande defeito de não prestar os serviços que são sua razão de ser. Com efeito, ela deve, antes de tudo, ter por objeto abreviar o trabalho científico ao substituir a multiplicidade indefinida dos indivíduos por um número restrito de tipos. Mas ela perde essa vantagem se esses tipos só forem constituídos após todos os indivíduos terem sido passados em revista e analisados inteiramente”, Durkheim (2007:81).

A multiplicidade de tipos ideais nas ciências sociais para a resolução de seus problemas científicos é fruto da necessidade imposta pela delimitação dos objetos 
de estudo. Porque, segundo Dahrendorf, “o homem total não só foge das dimensões de uma única disciplina, como provavelmente deverá permanecer sempre uma figura esquemática ao fundo do esforço científico. Devido à precisão e comprobabilidade de suas afirmações, toda a disciplina científica é obrigada a reduzir seu amplo objeto a determinados elementos, a partir dos quais pode ser sistematicamente reconstruído se não apenas como 'portrait' da realidade experimental ingênua, então pelo menos como estrutura em cuja tessitura se pode captar um aspecto da realidade”, Dahrendorf (1991:39).

A necessidade de se criar tipos-ideais com papeis específicos é evidente. Homo sociologicus, Homo oeconomicus, Homo juridicus, Homo politicus, psychological man são apenas alguns das criaturas ficcionais abstratamente construídas pela necessidade de se explicar os fenômenos sociais de âmbito das teorias científicas desenvolvidas pela Sociologia, Economia, Direito, Política e Psicologia, respectivamente.

O tipo-ideal é, portanto, uma abstração que somente pode fazer parte de um mundo abstrato e somente pode ser concebido no âmbito dos enunciados teóricos que lhe deram origem.

Apesar de existir neste mundo, não é dotado de existência física ou psicológica, estando, desde sua construção, dissociado de aspectos factuais, morais, éticos, psicológicos, sociais, políticos e de vários outros que permeiam o mundo real. Permite, assim, testar hipóteses e simular comportamentos por meio da criação de modelos teóricos.

\subsection{O individualismo metodológico: o tipo-ideal individualizado.}

Depois de construído o tipo-ideal este será utilizado como o indivíduo de referência para explicar os fenômenos sociais, utilizando uma das versões de individualismo metodológico. Segundo J. W. N. Watkins (1952b:43), “Individualistic ideal types of explanatory power are constructed by first discerning the form of typical, socially significant, dispositions, and then by demonstrating how, in various typical situations, these lead to certain principles of social behaviour.” 
O individualismo metodológico é um método filosófico que busca a compreensão de um todo divisível pela compreensão das suas partes componentes, e que os fenômenos verificados no todo têm individualmente suas causas delimitadas nas partes, tendo nestas a sua explicação. Conseqüentemente o ponto de partida da análise encontra-se no nível subjacente ao nível de ocorrência (ou de verificação) dos fenômenos observados.

A tese central do individualismo metodológico, de acordo com o mesmo autor, é a dedução e redução dos enunciados a propósito de grupos e coletividades a enunciados a respeito de partes individuais e de suas inter-relações. "The investigator of a system of interacting components would have abandoned methodological individualism if he did not believe that the system's overall behaviour could be deduced from (a) principles governing the behaviour of its components, and (b) descriptions of their situations ; or, to put it positively, if he believed that the behavior of its components could be deduced from (a) macroscopic laws which are sui generis and which apply to the system as an organic whole, and (b) descriptions of the positions (or functions) of the components within the whole”, Watkins (1952a:187).

A redução ao indivíduo permite a construção teórica das ciências sociais com o objetivo de explicar os fenômenos sociais identificados pelo observador e descrever a situação de ocorrência destes. E, ao explicar, dá origem a regras.

Lars Udehn (2002:497) entende que, estritamente falando, o individualismo metodológico é “(...) a principle, rule, or program telling historians and social scientists how to define collective concepts, explain social phenomena, and/or reduce macro to micro. Methodology is normative.”

A sociedade é formada por grupos sociais, e um grupo social por uma coletividade de pessoas (no caso, seres humanos). Sociedade e grupos sociais são coletividades que servem de referência lógica para representar a mesma unidade básica: o individuo. Resta claro, portanto, o caráter divisível, e que torna possível a redução.

Segundo Mário Bunge (2000:384), um indivíduo é “(...), of course, an object, whether concrete or abstract, that is undivided or is treated as a unit in some 
context or on some level. For instance, persons are individuals in social science but not in biology, which treats them as highly complex systems. Again, chemical and biological species are taxonomic units but not ontological individuals. As for individualism, it is the view that, in the last analysis, everything is either an individual or a collection of individuals. This is a strong and pervasive ontological thesis.”

As pessoas são unidades - indivíduos - para as ciências sociais, pois são vistas como as entidades mais básicas do sistema. São estes que produzem as causas e experimentam as conseqüências das interações ocorridas na coletividade de indivíduos. Por conseguinte, as interações sociais podem ser explicadas pelas interações entre indivíduos.

De acordo com Kenneth J. Arrow (1994:3), “The starting point for the individualist paradigm is the simple fact that all social interactions are after all interactions among individuals. The individual in the economy or in the society is like the atom in chemistry; whatever happens can ultimately be described exhaustively in terms of the individuals involved."

Presume-se que o indivíduo ao interagir e como conseqüência de sua interação produza e tenha acesso às informações relevantes e necessárias para que racionalmente possa empreender suas ações nas mais variadas situações. Avalia a situação, observa o ambiente, e identifica as informações de seu interesse e delas faz uso. São as mesmas informações que integrarão o processo decisório que está no âmago da Economia e do Direito.

Ao empreender uma ação, não há restrição das fontes de onde o indivíduo coleta as informações que considera relevantes. Isto o obriga a reconhecer a importância das instituições sociais, como o mercado e o Direito. Muitas das instituições sociais são regras que governam e determinam o comportamento individual em determinadas situações e, em muitos casos, dão origem a certos padrões de interação social.

Invariavelmente, as instituições são restrições formais e informais inventadas pelos seres humanos para estruturar as diversas formas de interação que 
ocorrem na sociedade. São fontes constantes e dinâmicas de informações e, por não serem homogeneamente difundidas entre os indivíduos, também são fontes de assimetria informacional.

Como a influência das instituições é real, não basta querer agir, é necessário poder agir. Agir, em conformidade com as práticas das instituições reconhecidas, as quais determinam condições, restrições e incentivos à ação e impõem sanções quando tais práticas não são observadas.

A existência de instituições na sociedade e o reconhecimento da influência que exercem, faz com que os indivíduos procurem racionalmente se informar sobre estas. O objetivo é adotar um comportamento esperado para a situação apresentada, tendo em vista alcançar um determinado fim: a prática da ação.

A estrutura social, assim, explica o comportamento do individuo: reflete, provavelmente, relações de poder, competição e conflito. Weber (2004:42-45) tratou assim as medidas típicas da gestão econômica racional, especialmente as associações.

Tendo em conta que não existe uma única instituição, é de se esperar que diferentes estruturas institucionais dêem origem a diferentes tipos de comportamentos esperados. Nada impede que o indivíduo participe simultaneamente de mais de uma estrutura social, o que o obriga a adotar diferentes tipos de comportamentos; cada um compatível com as instituições em consideração.

Não existe apenas uma única versão de individualismo metodológico, conforme salienta Udehn (2002:499-450). Uma destas versões é o individualismo institucional, cujo conceito foi criado por Agassi utilizando-se da análise situacional de Popper. Para Agassi, as instituições afetam o comportamento do indivíduo. O comportamento é adequado ao objetivo de acordo com as circunstâncias, Agassi (1960:247).

A diferença entre os individualismos, metodológico e institucional, é marcante. No primeiro, as instituições sociais (o todo) devem ser explicadas pelos indivíduos que dela fazem parte (as partes) e aparecem somente como conseqüências da 
explicação. No segundo, as instituições sociais fazem parte da explicação, aparecendo nos seus antecedentes.

Enquanto no individualismo metodológico as ações individuais não sofrem influência externa e têm suas causas restritas aos indivíduos, no individualismo institucional passam a ser limitadas pelas instituições e por outros indivíduos: isto é, pela situação. Este último restringe as possíveis àquelas que não violam os limites institucionais.

Uma forma particular de individualismo institucional é o individualismo estrutural. Tal como na sociedade, instituições podem surgir de organizações. Organizações são ficções dotadas de estruturas sociais igualmente compostas por indivíduos que ocupam transitoriamente posições socialmente definidas e exercem papéis essenciais para a existência e funcionamento da própria organização.

Todo individuo ocupa uma posição na sociedade. Seu comportamento deve ser compatível com o papel a ele atribuído. Devendo estar em conformidade com as regras existentes. Assim, a própria formação da organização determina o comportamento esperado do indivíduo dentro do âmbito de atuação da organização.

A tradição do individualismo metodológico na Economia Neoclássica trabalha com pressupostos mais restritos. Knight (1957:78) fez uma boa síntese. "Every member of the society must act as an individual only, in entire independence of all others. To complete his independence he must be free from social wants, prejudices, preferences, or repulsions, or any values which are not completely manifested in market dealing."

A restrição exposta por Knight é fruto do psicologismo e da tentativa de se construir uma ciência econômica inspirada nas ciências naturais. Pareto (1909:14) usou de analogia para exemplificar a abstração necessária para determinar o que, no seu entendimento, seria o objeto de estudo da Economia: a ação econômica.

Afirmou que isolar a ação econômica, abstraindo-a de todas as demais influências, é equivalente, na Química, ao estudo do enxofre ou do oxigênio 
quimicamente puros. É uma abstração porque esses elementos químicos não são encontrados na sua forma pura na natureza, e sim misturados com outros elementos.

A origem do psicologismo na Economia como explicação da ação econômica pelos interesses e preferências do indivíduo está nas obras de John Stuart Mill e de Carl Menger, Swedberg (2005:84). Entretanto, nenhum dos dois elaborou completamente o conceito do individualismo metodológico utilizado pela Economia, (Arrow, 1994:2).

Mill (1844:137) limitou-se a apresentar as características e os comportamentos que considerava relevantes. Para ele, a Economia deveria centrar-se no desejo de possuir riqueza e na capacidade de julgar a eficácia comparativa dos meios para obtê-la, a despeito de todos os demais comportamentos humanos. Assim, a Economia deveria limitar-se ao comportamento auto-interessado economicamente orientado.

Smith (1983:50), antes de Mill, já havia registrado que o homem realiza trocas mutuamente vantajosas no mercado motivado por interesse e não pela benevolência. Entretanto, o interesse para Smith é diferente da noção de auto-interesse presente nas obras dos economistas que o sucederam. Ele reconhece o comportamento auto-interessado e o defende em situações específicas, mas nem de longe o considera como preponderante e indispensável para o homem, Sen (2006:38-44).

Segundo Oliva (1994:19-20), o individualismo propugnado por Smith, Mill e outros britânicos aos olhos de alguns autores da Sociologia pareceu “descambar para uma espécie de implausível 'egocentrismo atomista': os cursos de ação empreendidos pelos indivíduos são frutos do exercício de seu pensamento e de sua vontade em contextos de troca simbólica e material; são determinados por fatores imanentes ao cálculo de seus interesses em situações específicas de interação; o campo ontológico da ação individual é intranscendível, já que a novidade da vida social reside na geração do ‘efeito agregativo’ e na promoção de finalidades que não faziam parte das intenções isoladamente acalentadas pelos indivíduos.” 
Diferentemente dos seus antecessores, Weber (2004: 15) forneceu os aspectos metodológicos do individualismo para as ciências sociais com o desenvolvimento do conceito de “ação social”. Contudo, foi Schumpeter, ex-aluno de Weber, quem cunhou o termo individualismo metodológico.

Para Schumpeter (1909:231), o individualismo metodológico “descreve um modo de procedimento cientifico o qual naturalmente não leva a nenhuma concepção errônea dos fenômenos econômicos”.

De acordo com Swedberg (2005:46), para Weber, “a unidade básica da sociologia é o individuo ou, mais precisamente, as ações sociais do individuo.” O individualismo weberiano possui conteúdo subjetivista, pois está diretamente ligado à idéia de sociologia interpretativa que busca a compreensão das causas da ação social.

As causas, tal como o interesse, têm origens nos aspectos psicológicos de cada individuo. Somente podem ser conhecidas indiretamente pela análise e compreensão dos meios utilizados para a ação e da ação em si, pois a mente é inacessível. Esta inacessibilidade origina a necessária presunção de que todas as ações são racionais sem, contudo, negar a existência de ações irracionais.

As diversas estruturas sociais determinam os limites para a ação econômica. Em alguns casos, o indivíduo adotará um comportamento predominantemente atomista, valorizando seus interesses. Em outros, o comportamento valorizará as influências de suas relações sociais. Independentemente do comportamento adotado, é necessário que este seja compatível com as instituições sociais.

Ao contrário de toda a evolução e amadurecimento metodológico experimentado pela Economia, o Direito ainda se pretende a conceitos impróprios para esta finalidade.

Apesar de serem construções deliberadas, não são destinadas ao uso metodológico, não se pode dizer que o bonus pater familias, o homem médio do Direito 
e o Homo juridicus de Supiot e Del Vecchio sejam tipos-ideais ou mesmo sigam o individualismo metodológico.

\subsection{A Lógica Situacional: o autismo acaba aqui.}

Para que o Homo oeconomicus seja transposto para o Direito, adotando o “pseudônimo” de Homo juridicus é necessário flexibilizar, ou relaxar uma de sua hipóteses. Neste sentido é importante que ele esteja aberto e sofra outras influências, não se prendendo apenas aos preços ou, no Direito, às normas jurídicas.

Popper é da opinião de que é possível a compreensão objetiva das ações dos indivíduos deixando de lado o psicologismo. Ao invés de explicar os fenômenos sociais partindo de idéias subjetivas ou psicológicas, como faz o psicologismo, ele sugere um método individualista que as rejeita: a análise situacional.

A análise situacional permite considerar a influência de aspectos históricos e institucionais responsáveis pela situação social dos indivíduos no momento em que suas ações foram empreendidas para a busca de alvos objetivos. Isto permite ressaltar a importância das instituições. “A compreensão objetiva consiste em considerar que a ação foi objetivamente apropriada à situação”, Popper (2004:31).

Instituições são produtos dos indivíduos. Algumas nascem consciente e intencionalmente delineadas, e outras como produtos involuntários do resultado de suas ações. Para Popper (1998:101), “a estrutura de nosso ambiente social é feita pelo homem em certo sentido; no de que suas instituições e tradições nem são obras de Deus nem da natureza, mas resultados das ações e decisões humanas, alteráveis por ações e decisões humanas.”

A concepção de individualismo existente na análise situacional difere da concepção do individualismo tradicional. O indivíduo passa a influenciar e ser influenciado pelo ambiente tendo suas ações por este delimitadas. A incapacidade de o individuo se auto-suficiente o leva a interagir socialmente. Desta interação surgem limites que restringem as ações do individuo, sobrepondo-se aos motivos psicológicos que o levariam a agir. 
Segundo Popper (2004:33), “a lógica situacional também deve admitir um mundo social, habitado por outro povo, de cujas metas sabemos alguma coisa (muito pouco), e, deve admitir, além de tudo, as instituições sociais. Essas instituições sociais determinam o peculiar caráter social de nosso meio social. Essas instituições sociais consistem de todas as realidades sociais do mundo social, realidades que, em algum grau, correspondem às coisas do mundo físico.”

De acordo com Hedström, Swedberg e Udehn (1998:350), o método de análise situacional de Popper é similar ao de Max Weber, em especial porque concordam que a ação humana é adequada à situação pelo indivíduo.

Tal como na obra de Weber, Popper entende que as ações são sempre desempenhadas pelos indivíduos, nunca pelas instituições. “As instituições não agem; ao invés, só os indivíduos agem, dentro ou para ou através das instituições. A lógica situacional geral destas ações será a teoria das quase-ações das instituições” Popper (2004:33).

\subsection{O egoísmo ético: o homem deveria ser egoísta, mas não é.}

A definição de egoísmo, em sentido amplo, abrange o egoísmo psicológico e o egoísmo ético. O egoísmo é de difícil constatação empírica, pois está relacionado com aspectos psicológicos que direcionam a conduta do individuo. Não seria verdadeiro, pois, assumir que todos os indivíduos são a priori egoístas, mas é possível supor que os indivíduos, buscam o aumento do seu bem-estar tendo em vista o interesse na própria sobrevivência.

Seria justo supor, também, que nem sempre o individuo age racionalmente de acordo com seu auto-interesse ou busca a máxima eficiência na alocação de seus recursos. Deixando de lado aspectos subjetivos, como preferências, gostos, aversões e valores, e aspectos objetivos, tais como métodos de cálculo e critérios de escolha.

Contudo, se o indivíduo busca a sua sobrevivência, deveria agir de acordo com o seu auto-interesse e em busca da máxima eficiência na alocação de seus 
recursos. Este tipo de comportamento, que rejeita o domínio do psicologismo, é chamado de egoísmo ético.

Dawkins apresentou as definições de comportamento egoísta e altruísta, considerando apenas os aspectos comportamentais sem preocupar-se com a psicologia dos motivos do comportamento. Segundo Dawkins (2001:24), “uma entidade, tal como um babuíno, é dita altruísta se ela se comporta de maneira a aumentar o bem-estar de outra entidade semelhante, às suas próprias custas. O comportamento egoísta tem exatamente o efeito contrário. 'Bem-estar' é definido como 'possibilidades de sobrevivência', mesmo se o efeito sobre a expectativa de vida e de morte for tão pequeno que pareça desprezível.”

A predominância do egoísmo ético no comportamento pode ser explicada pela busca de bem-estar e aumento da sobrevivência do individuo. É, pois, um comportamento que pode ser presumido e não impede o comportamento altruísta ou cooperativo, nem mesmo o desenvolvimento de relações baseadas em confiança ou reciprocidade.

Altruísmo, cooperação, confiança e reciprocidade podem ter como origem o comportamento auto-interessado, servindo de meios para alcançar um fim específico. Para o observador, que desconhece os verdadeiros motivos que levaram o individuo a adotar tais comportamentos, o comportamento observado será compatível com o que o individuo permitiu transparecer.

\subsection{Racional, nem que seja de "mentirinha".}

A Filosofia ocidental, pelo menos a partir do século XVII, pressupõe que o cientista é racional. O Homo oeconomicus e o agente compartilham com o cientista a mesma característica. São ambos racionais. O problema reside no fato do que significa ser racional. Racional, como normalmente tratado nos livros de Teoria da Decisão, significa uma pessoa capaz de fazer uma escolha coerente e racional. Nesse sentido racional significa ser coerente, lógico. 
'We therefore use instead the term 'coherent' and refer to coherence as a desirable property in choosing a decision”, Lindley (1975:3).

A qualidade de ser racional é indispensável ao Direito, da mesma forma que o é para a Economia.

“O comportamento racional dos agentes econômicos é sempre o pressuposto inicial de qualquer análise ou estudo e elaboração de estratégia de investimento. Assume-se que a medição sempre prevalece sobre a intuição e que portanto os indivíduos racionais escolhem as alternativas baseados em informações, e não com base na emoção, no capricho, no ‘tino administrativo’ ou no hábito. Quando todas as informações são analisadas, esses indivíduos tomam decisões de acordo com preferências bem definidas”, Souza (2007:32).

Se o indivíduo não for racional, além de rapidamente esgotar seus recursos, colocando em risco a sua sobrevivência, ele não conseguirá viver em sociedade, pois o Direito não apenas segrega os seres humanos pela sua razão, mas também sem esta ele não conseguirá o conteúdo das normas jurídicas e, conseqüentemente não conseguirá interagir socialmente.

Ser racional, no caso obedecendo unicamente a razão, somente pode ser considerado abstratamente. A lógica, neste aspecto é a principal ferramenta que comporá sua racionalidade e permitirá a decisão mais isenta.

"I am about to build up a highly idealized theory of behavior of a 'rational' person with respect to decisions. I am doing so I will of course, have to ask you to agree with me that such maxims of behavior are 'rational'. In so far as 'rational' means logical, there is no live question; and if I ask your leave there at all, it is only a matter of form”, Savage (1972:7).

O pressuposto comum ao Homo oeconomicus e ao Homo juridicus é ser racional, sem isso não seria possível admitir qualquer forma de racionalidade, para compreendê-la apresenta-se o entendimento que parece ser pertinente acerca do ser 
“racional” em relação a condutas, sem, contudo, discutir outros possíveis entendimentos.

A premissa do ser racional é necessária às ciências sociais, pois "se as pessoas não se comportam de maneiras previsíveis, então a idéia de que podemos regulamentar a sociedade por meio de leis e incentivos se torna impraticável (...). Esse uso da hipótese de racionalidade considera o homem econômico como média ponderada do grupo de indivíduos em exame. Permite, assim, a existência de marcantes nas reações individuais”, Veljanovski (1994:47). Esta premissa, apesar de formulada e direcionada a Economia, por extensão, pode ser aplicada ao Homo juridicus.

Segundo W. M. Sibley (1953:555-556), o uso do termo “racional” possui as seguintes implicações: “(i) With regard to the ends I propose to myself, it entails: (a) that I should have an informed awareness of the nature of the ends I am proposing to achieve, including in this awareness a realization of their significance as they affect other ends, not only of myself, but also of others affected by my actions; and (b) that in case of a conflict between two of my proposed ends, I select that end which I really prefer, i.e., that end which, after informed and careful reflection, taking into account my own experience and what I know of the experience of others, I judge to be of more value to me than its competitor. (ii) With regard to the means proposed to reach these rationally chosen ends, it entails that I select those means which, on the best available evidence, are the most effective way of realizing those ends; and that I take cognizance of all other measures lying in my power which are necessary to safeguard the attainment of my ends. (B) With regard to my will, it entails that I act in accordance with the decisions reached by this process of reflection, not allowing any emotional influences to persuade me to a contrary course. To fail in any or all of these respects is to be irrational, in the sense of being foolish, absurd, unintelligent. Thus, I behave irrationally when I do not bother to ascertain the true nature of the ends I set myself; or when I heedlessly sacrifice one end to a second, which when attained I find to be of less worth to me than the first would have been; or when I select unrealistic means; or when, having reached a rational enough decision, I fail to implement that decision in practice. Rationality-in these senses of the word at any rate-is essentially an intellectual virtue, though it includes secondarily a reference to the will as well.” 
Uma possível interpretação da utilização do termo "racional” poderia levar a pressuposição de que os atos (ou comportamentos) racionais são utilitaristas, contudo o próprio Sibley (1953:559-560) explica.

"A man who is rational, then, is not ipso facto a utilitarian. Qua rational, he will act so as to achieve what is to him a greater value; he will do what he really prefers to do. But this fact sheds no light on what he really prefers to do. If, however, he does prefer to act reasonably, then he will necessarily, in reasoning out his conduct, heed the sense of the utilitarian maxim”.

Mesmo que a Psicologia advogue no sentido de relativizar a condição de racional do ser humano, fato é mesmo que o homem não aja racionalmente pelo menos na grande maioria das situações que experimenta ao longo da sua existência, considerálo como tal é uma necessidade. Caso contrário, conforme já dito, como seria possível regular a vida em sociedade?

O comportamento não-racional traz consigo a imprevisibilidade, não apenas em relação ao comportamento, mas também em relação ao resultado desse comportamento. A imprevisibilidade decorre da impossibilidade de aprendizado consciente e deliberado.

Portanto, se se pretende minimamente reduzir a entropia na sociedade, é necessário que o homem abstratamente considerado seja considerado racional, capaz de aprender, deliberar e conscientemente direcionar seus desejos e crenças para agir em direção a um determinado objetivo. Deve, assim, ser dotado de alguma racionalidade prática.

No processo de deliberação consciente o homem busca informações e dados, e adéqua-se ao ambiente. Tal como Karl Popper sugere com a Análise Situacional. Ao invés de explicar os fenômenos sociais partindo de idéias subjetivas ou psicológicas, como faz o psicologismo, a análise situacional permite considerar a influência de aspectos históricos e institucionais responsáveis pela situação social dos indivíduos no momento em que suas ações foram apropriadamente empreendidas para a busca de alvos objetivos. E se a ação é compatível com a situação. 
Apenas abstratamente podemos conceber uma ação desprendida do ambiente e das relações sociais. No processo decisório, buscam-se dados e informações para decidir. Quanto maior o volume e o número de fontes de informações que modifiquem a opinião sobre um determinado estado da natureza (ou evento), melhor.

Mas essa busca envolve tempo, custo, processamento e aprendizado. E o homem possui restrições em todos eles. Por isso, o homem busca aquilo que considera ideal, ou suficiente, para a situação que se encontra, de acordo com a conseqüência que a sua ação terá.

Assim, não seria razoável procurar em todas as lojas e supermercados da cidade aquele que possui o menor preço de uma mesma barra de chocolate antes de comprá-la, para com isso maximizar os recursos disponíveis (ou a sua dotação inicial de recursos).

Da mesma forma, não seria razoável conceber que a decisão por comprar uma empresa no valor de R\$ 100 milhões seja tomada em 15 minutos e apenas com base numa conversa informal com os acionistas da empresa, sem qualquer informação ou dado adicional que corrobore com a versão dos acionistas. São dois extremos do mesmo problema. Como a decisão é tomada?

Na primeira situação, a maioria das pessoas sequer entrará numa segunda loja, mesmo que para isso tenha que andar apenas míseros 100 metros. Mas na segunda, dificilmente será encontrado um investidor que concluirá o negócio sem antes ter se cercado de informações e dados suficientes para analisar a empresa.

E mesmo assim existirão aqueles que, por algum motivo desconhecido, não estavam disponíveis no momento, ou, ainda, situações imprevisíveis que fogem ao controle tanto do investidor quanto do acionista. Isto porque toda decisão mais complexa, que envolve um número maior de variáveis, é tomada com informações incompletas. Cabe ao indivíduo decidir da melhor forma sem que disponha de todas as informações que seriam necessárias. Ser inteligente é, assim, tomar a melhor decisão com poucas informações ou informações incompletas. 
Não é possível dizer que nos dois casos o homem busca maximizar seus recursos, ou que não busca. Ou, ainda, que não agirá racionalmente se buscar o preço do chocolate em todos os supermercados, ou mesmo se fechar o negócio nos 15 minutos de conversa informal, celebrando a compra por meio de um simples contrato que acabou de redigir de próprio punho num pedaço de papel.

O que se pode dizer é que racionalmente o homem busca a sua autopreservação, e os recursos que dispõe o ajudam nesta tarefa. Conseqüentemente buscará utilizá-los de modo a atender todas as suas necessidades prementes e essenciais, afinal seus recursos são limitados, mas as necessidades (e, porque não, desejos), são ilimitadas.

Toda e qualquer decisão é feita em primeira pessoa. É o indivíduo quem decide e escolhe. Mesmo numa empresa, uma ficção jurídica dotada de personalidade própria, quem decide é uma única pessoa ou um grupo de pessoas em consenso.

A decisão do outro, apesar de também ser em primeira pessoa, é a decisão dele. Por isso ao encarar a decisão do outro sempre em terceira pessoa invariavelmente são encontradas situações nas quais não se dispõe de informações sobre a outra pessoa (i.e. seu comportamento, gostos, formação, caráter), e mesmo quando é possível obtê-las, devido à impossibilidade de se ler a mente do outro, não há certeza do que ele fará. Assim, como fazer?

Se o indivíduo considerar o outro como um igual, poderá estar inadvertidamente supervalorizando as suas próprias características e atributos e subvalorizando as do outro. O resultado será, portanto, potencialmente negativo. Se, por outro lado, subjugar o outro, novamente o resultado poderá ser ruim. Uma solução é considerar que o outro é superior, possuindo os atributos e características que tendem a prejudicar o resultado que poderá advir da ação que será tomada.

Mas isso implica na sub-valorização do "eu”, algo com o qual os indivíduos não estão nem de longe acostumados a fazer: reconhecer humildemente a própria inferioridade frente a terceiros. Portanto, por mais que o ser humano não seja racional todo tempo, buscando maximizar seus recursos, precisa considerar que o seu 
opositor agirá desta forma. Pelo menos ao deliberar hipoteticamente. O que não impede que eventuais concessões possam vir a ser feitas ao interagir com o outro no mundo real. Se o Homo oeconomicus não é altruísta, nada impede que a ação do homem real seja tomada nesse sentido.

Portanto, se o homem não age de acordo com valores éticos ou morais, não é por causa do Homo oeconomicus e sim porque o próprio homem colocou em segundo plano os valores que para terceiros podem parecer, segundo Amartya Sen "uma rejeição do papel da ética na real tomada de decisão, Sen (2006:31).”

Admitir que o outro hipoteticamente agirá buscando maximizar suas preferências não significa assumir que o homem tem nesta conduta a única fonte motivadora de suas ações, longe disso. Mas por ser capaz de agir neste sentido e tê-la como motivadora, e sendo o auto-interesse do outro prejudicial aos interesses do indivíduo, prudentemente é preferível assumi-la hipoteticamente como característica dominante. Pois havendo discrepância entre a hipótese e a realidade, sempre a realidade prevalecerá.

É importante notar que o auto-interesse somente é relevante nas discussões de caráter ético ou moral do comportamento humano ao decidir. Nos livros de Microeconomia ele encontrado como um axioma de preferências juntamente com o pressuposto da maximização.

O mesmo pode ser dito nos livros de Teoria da Decisão. Será encontrada a busca pela maximização dos interesses próprios, e para isso ordenam-se as preferências individuais. Basta, para isso, atribuir a certos bens uma dimensão ética ou moral.

Por exemplo, escolher entre implantar uma siderúrgica próxima a um rio e lançar os dejetos sem tratamento em suas águas, ou incluir uma estação de tratamento de resíduos. Como a decisão é tomada em primeira pessoa, e os interesses são do próprio agente, qualquer consideração sobre a motivação pelo auto-interesse é irrelevante. Além do que, nunca se saberá se um comportamento altruísta não faz parte de uma estratégia previamente deliberada e de cunho auto-interessado. 
Sen (1977:25) preocupa-se desnecessariamente com a escolha e a utilização de pressupostos que sabidamente não são verdadeiros. Por outro lado, a pergunta feita por ele pode ser formulada de outra forma. Por qual motivo deve-se utilizar características que sabidamente serem verdadeiras e fazem parte das limitações do ser humano?

Não é difícil concluir que o homem não age apenas movido pelo autointeresse. Se isso fosse verdade não emergiria a cooperação e estado de natureza prevaleceria, onde haveria a guerra de todos contra todos. Mas também é fácil concluir que o homem não age somente altruisticamente, pois ao se comportar freqüentemente desta forma aumentaria a possibilidade de sobrevivência da outra às suas próprias custas, e no limite, o levaria à morte. "Um aparentemente altruísta é aquele que parece, superficialmente, tender a aumentar (não importa quão ligeiramente) a probabilidade do altruísta morrer e do favorecido sobreviver”, Dawkins (2001:24).

Essa é uma escolha ética ou moral, a qual está, a princípio, à margem da Economia positiva, e de qualquer outra ciência positiva, como, por exemplo, do Direito Positivo.

A tentativa de considerar valores éticos ou morais como padrões (ou guias) para a ação não é produtiva. A começar pelas questões tradicionais. Ética ou moral de quem? De quando? Da onde? É possível um conjunto abrangente de critérios morais que contemple todas as diversas situações as quais os homens estão expostos e que surgirão no futuro e, ao mesmo tempo, possua validade universal e não esteja exposto à contraditoriedade? Dificilmente.

São perguntas que devem ser respondidas antes de tentar utilizar ética e moral como argumentos contra ou a favor de hipóteses e pressupostos do Homo oeconomicus ou do Homo juridicus em especial porque somente possuem significados quando atrelados ao mundo real - em casos concretos. Não é possível, portanto, generalizar e abstrair certas nuances que fazem parte do comportamento humano e que servem como limitadores da ação humana. 


\subsection{A Teoria dos Três Mundos.}

Para melhor situar o Homo juridicus e o Homo oeconomicus é necessário restringir o seu plano de existência. Não seria racional esperar encontrar com o primeiro nos corredores do fórum, nas calçadas ou em qualquer o outro lugar. O segundo também não será encontrado nas instituições financeiras e nas empresas.

Isto porque são entidades abstratas, ficções metodológicas, tipos-ideais construídos com fins determinados. Sua existência somente pode ser concebida no que Popper denominou terceiro mundo.

Karl Popper ${ }^{35}$ elaborou uma teoria que permite identificar e compreender os diferentes mundos com os quais os seres humanos interagem, partindo da tradicional separação entre corpo e mente.

De acordo com Popper, o primeiro mundo (o mundo físico) consiste dos corpos materiais, com existência física, e pode ser dividido em dois sub-mundos: o mundo dos objetos físicos vivos - unidades vivas, por exemplo, plantas e animais - e o mundo dos objetos físicos não-vivos - unidades não vivas, por exemplo, materiais inanimados, radiação e outras formas de energia física.

O segundo mundo (o mental ou psicológico) consiste de estados ou processos mentais ou psicológicos, ou de experiências subjetivas, por exemplo, dor, prazer, pensamentos, observações e decisões. Conseqüentemente este mundo pode ser dividido de várias formas, por exemplo, o mundo das experiências conscientes e o mundo das experiências subconscientes.

O terceiro mundo (o dos produtos da abstração da mente humana) é composto por objetos abstratos, tais como: linguagem, contos e estórias, mitos religiosos, conjecturas e teorias cientificas, construções matemáticas, e outras criações da mente humana. Estas são ferramentas que permitem a realização de mudanças no primeiro mundo. Note-se que alguns dos produtos da mente humana fazem parte do

\footnotetext{
${ }^{35}$ Popper (1999:151-179), Popper e Eccles (1986:36-50), e Popper (1978).
} 
primeiro mundo, como esculturas, pinturas e livros. Tal como nos dois primeiros, o terceiro mundo pode ser dividido em outros, como ficção e ciência, arte e engenharia.

A interação entre os mundos é evidente e necessária, pois existe relação entre os objetos do primeiro mundo e os objetos do terceiro mundo. Os objetos do terceiro mundo somente podem produzir efeitos no primeiro mundo através da intervenção humana. É natural que a interação entre o primeiro mundo e o terceiro mundo sofra necessariamente a intervenção dos processos mentais que ocorrem no segundo mundo ${ }^{36}$.

Da exposição acima, pode-se concluir que os seres humanos estão situados no primeiro mundo, e é nele que os relacionamentos sociais acontecem, enquanto as entidades abstratas encontram-se no terceiros, visto que são criações da mente humana.

Ao demarcar o plano de existência do Homo Juridicus e do Homo oeconomicus fica clara a sua finalidade. Evidente, também, é o seu uso e o motivo pelo qual o homem médio do Direito e o bonus pater familias são insustentáveis metodologicamente.

36 Popper e Eccles (1986:47) e Popper (1999:152) 


\section{CONCLUSÃO.}

Partindo da análise da evolução histórica de alguns termos corriqueiramente utilizados no Direito e comparando-os com a evolução do Homo oeconomicus e a abordagem de Supiot, Del Vecchio e, ainda, da alternativa proposta pela Teoria dos Sistemas, fica claro que nenhum deles tem finalidade metodológica. Este fato sustenta a afirmação feita de que a metodologia jurídica não emprega esforços em teorizar sobre o indivíduo.

Da discussão entre raciocínio e da racionalidade é possível vislumbrar a necessidade de uma tese ontológica para o Direito. Apesar das discussões acerca da racionalidade (ou razão) prática, em voga na doutrina jusfilosófica, entende-se que antes de se empregar grande esforço na análise das decisões judiciais e na realização do Direito faz-se necessário determinar qual figura- a tese ontológica sobre o indivíduo será central à metodologia jurídica e que possibilitará a construção sistemática da teoria necessária para efetuar tais análises. Sem a teoria fica prejudicada toda e qualquer análise mais consistente.

Procurou-se apresentar a dificuldade acerca dessa discussão por meio da apresentação de dois pressupostos bastante fortes que são utilizados pelo Legislador. Pressupostos estes devem ser considerados na construção da tese ontológica. A primeira vista indicariam que o próprio Legislador delineou intencionalmente algumas das características necessárias à construção desta tese. São características individuais que integram os pressupostos necessários para garantir a realização do Direito e permitir que a sociedade esteja sob o controle por meio das decisões judiciais.

Contudo, ainda que presentes, tais características são insuficientes sendo necessário complementá-las. A razão, necessária para que se possibilite o controle social por intermédio do direcionamento das condutas dos indivíduos, é outra destas características. O próprio Direito segrega aqueles que não agem racionalmente.

Outra consideração importante diz respeito ao conceito de pessoa. A debilidade e fragilidade com que foram historicamente tratadas e ainda continuam 
sendo, permite o surgimento de inconsistências no próprio sistema jurídico. O tratamento de exceções para agasalhar eventuais diferenças étnicas, sociais, e preferências sexuais e assim por diante, longe de permitir uma melhor realização do Direito, enfraquecem o conceito de pessoa. A pessoa é única e independe de sexo, raça, religião e preferências.

Uma tese ontológica, qualquer que seja, deve ser suficientemente robusta e incluir todos estes aspectos, não permitindo espaço para incertezas terminológicas que dificultam o uso e prejudica a atribuição de sentido e significado. Estes são problemas que decorrem da característica excessivamente argumentativa do Direito, que acabou por transformá-los em lugares comuns, instáveis e indefinidos.

A solução apresentada foi a substituição destes conceitos por uma tese ontológica que possui raízes históricas similares e cujo papel social se confunde com o próprio Direito e com o uso dado pelo Direito se considerada todas as suas dimensões, não apenas aquelas que são encontradas na doutrina jurídica.

O Homo oeconomicus como resultado evolutivo do oikodespótes e do pater familias assumiria este papel. As principais vantagens de utilizá-lo são:

(a) permite a continuidade histórica e evolutiva do conceito de pater familias. Se o oikodespótes é o ancestral do pater familias ele também o é com relação ao Homo oeconomicus. Inexistiria, assim, ruptura;

(b) o estágio evolutivo atual do Homo oeconomicus, como conseqüência de diversas críticas sofridas, possibilita o reconhecimento de suas limitações bem como das vantagens de seu uso. Não se nega as imperfeições deste tipo-ideal, elas são inerentes ao próprio conceito de tipo-ideal;

(c) por se tratar de um tipo-ideal, diferentemente dos demais conceitos apresentados, devido à sua flexibilidade inerente à abstração, permite que sejam realizados ajustes em suas características de modo a melhor adequá-lo ao Direito. Prova disso é o individualismo institucional em uso na Economia Institucional que considera o próprio Direito como informação para a ação e, para isso, o expôs a outras informações 
que podem ser encontradas na sociedade, não somente nos preços verificados nos mercados. Com relação à racionalidade, quer seja ela econômica ou jurídica, pouco importa. A ênfase deve ser dada na determinação das preferências, pois são elas que serão conciliadas com os fins pretendidos. E estes fins podem ser puramente econômicos ou considerar a moral, a ética;

(d) possibilita que seja criado um mediador para estabilizar o ajuste da norma ao indivíduo, evitando, assim, que o indivíduo seja ajustado á norma. Ao se fazer isso, reduz-se o a instabilidade resultante da determinação do conteúdo e limite do modelo de indivíduo utilizado, a qual é realizada para cada caso concreto. O papel de mediador não estabilizará por definitivo como ocorre na Economia com relação às suas teorias e ao seu uso, mas reduzirá sobremaneira a instabilidade atualmente existente.

Este trabalho, longe de esgotar o tema, buscou trazer à discussão a necessidade de se criar uma tese ontológica sobre o indivíduo própria para o Direito. Na falta desta, não haveria objeção à utilização do Homo oeoconomicus em seu lugar. 


\section{REFERÊNCIAS BIBLIOGRÁFICAS.}

ALVES, José Carlos Moreira. Direito Romano. 14. ed. Rio de janeiro: Forense, 2008.

ARENDT, Hanna. The life of the mind. Nova Iorque: Harcourt Brace \& Company, 1978. pp.254-272.

ARROW, Kenneth J. Methodological individualism and social knowledge. The American Economic Review, Vol. 84, No. 2, Papers and Proceedings of the Hundred and Sixth Annual Meeting of the American Economic Association. (May, 1994), pp. 19.

BAGEHOT, Walter. Economic studies. 17 ed. Londres: Longmans, Green \& Co,1908.

BECKER, Gary S. The economic approach to human behavior. Chicago: The University of Chicago Press, 1990.

BECKERT, Jens. Beyond the market: the social foundations of economic efficiency. Princeton: Princeton University Press, 2002.

BEIRNE, Piers. Adolphe quetelet and the origins of positivist criminology. The American Journal of Sociology, Vol. 92, No. 5 (Mar., 1987), pp. 1140-1169.

BELL, John. The acceptability of legal arguments. In. MACCORMICK, Neil; BIRKS, Peter (ed). The legal mind: essays for tony honoré. Oxford: Claredon Press, 1986.

BEVILAQUA, Clovis. Código civil dos Estados Unidos do Brasil, comentado por Clovis Bevilaqua. Edição histórica. Rio de Janeiro: Ed. Rio, 1973.

BUNGE, Mario. Ten modes of individualism none of which works and their alternatives. Philosophy of the Social Sciences, 2000, 30(3): 384-406.

CARVALHO DE MENDONÇA, Manuel Inácio. Doutrina e prática das obrigações ou tratado geral dos direitos de crédito. 4. Ed. Rio de Janeiro: Forense, 1956.

CASTAN, Nicole. O público e o particular. In CHARTIER, Roger (org). História da vida privada. São Paulo: Companhia das Letras, 2009. v.3: da Renascença ao Século das Luzes. Império Romano ao ano mil. p.p. 402-438.

CASTANLHERIA NEVES, Antônio. Metodologia jurídica. Coimbra: Coimbra Editora, 1993.

CHAMOUN, Ebert. Instituições de Direito Romano. 5 ed. Rio de Janeiro: Forense, 1950.

CHAUÍ, Marilena. Introdução à história da filosofia. v.1, 2. ed, São Paulo: Companhia das Letras, 2003. 
CICERO, Marcus Tullius. Letters to atticus. Londres:William Heinemann Ltd, 1961. v.3.

CLARK, Michael. Paradoxes from a to z. 2 ed. Nova Iorque: Routledge, 2007.

COLLOMP, Alain. Famílias, habitações e coabitações. In: In CHARTIER, Roger (org). História da vida privada. São Paulo: Companhia das Letras, 2009. v.3: da Renascença ao Século das Luzes. Império Romano ao ano mil. p.p. 482-520.

COMTE-SPONVILLE, André. O capitalismo é moral? São Paulo: Martins Fontes, 2005

COOPER, John M. Plato. Complete works. Cambridge: Hackett Publishing, 1997.

CORREIA, Alexandre; SCIASCIA, Gaetano. Manual de direito romano. Rio de Janeiro: Freitas Bastos, 1961.

DAMÁSIO, Antônio. O erro de Descartes: emoção, razão e o cérebro humano. São Paulo: Companhia das Letras, 1996.

DAHRENDORF, Ralf. Homo sociologicus. Ensaio sobre a história, o significado e a crítica da categoria de papel social. 2 ed. Rio de Janeiro: Tempo Brasileiro, 1991

DAWKINS, Richard. O gene egoísta. Belo Horizonte: Itatiaia, 2001.

DIAS, José de Aguiar. Da Responsabilidade Civil. 11. ed. Rio de Janeiro: Renovar, 2006.

Diccionario de la lengua española. 22a ed. Madri: Real Academia Española, 2003. Edición Electrónica. V. 1.0.

Dicionário eletrônico houaiss da língua portuguesa. Versão 1.0. Rio de Janeiro: Editora Objetiva, 2001.

Dizionario interativo etimologico. Bolonha: Zanichelli Editore, 2000.

DURKHEIM, Émile. As regras do método sociológico. São Paulo: Martins Fontes, 2007.

ELSTER, Jon. "The Case for Methodological Individualism." Theory and Society, 11(4): 453-482, 1982.

Encyclopédie de diderot et d'alembert. v.1.0. Édite par Redon.

FERRAZ JR., Tércio. Introdução ao estudo do direito: técnica, decisão, dominação. $4^{\mathrm{a}}$ ed. São Paulo: Atlas, 2003. 
FERREIRA, Aurélio Buarque de Holanda Ferreira. Novo dicionário aurélio século xxi: o dicionário da língua portuguesa. $3^{\text {a }}$ ed. Rio de Janeiro: Nova Fronteira, 1999.

FOUCAULT, Michel. 2007. Microfísica do poder. 24a ed. São Paulo: Graal.

FREYRE, Gilberto. Sobrados e mucambos. Decadência do patriarcado rural e desenvolvimento urbano. 15 ed. São Paulo: Global Editora, 2004.

Casa-grande \& senzala. 51 ed. São Paulo: Global Editora, 2006.

FUSTEL COULANGES, Numa Denis. A cidade antiga. 5.ed. São Paulo: Martins Fontes, 2004.

GOMES, Orlando. Obrigações. 16 ed. Rio de Janeiro: Forense, 2006.

GIANETTIi, Eduardo. Mercado das crenças: filosofia econômica e mudança social, 2003. São Paulo: Companhia das Letras, 2003.

GRIM, Patrick. There is no set of all truths. Analysis, Vol. 44, No. 4 (Oct., 1984), pp. 206-208

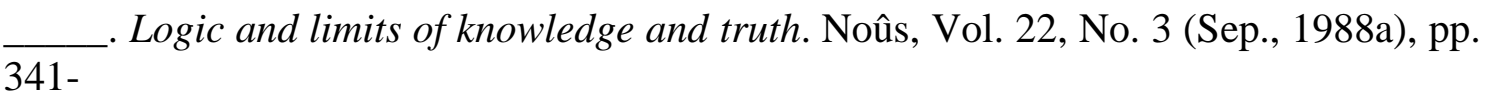

Truth, omniscience, and the knower. Philosophical Studies: An International Journal for Philosophy in the Analytic Tradition, Vol. 54, No. 1 (Jul., 1988b), pp. 9-41

GROVES, John (ed). A greek and english dictionary comprising all the words in the writings of the most popular greek authors; with the difficult inflections in them and in the septuagint and new testament: designed for the use of schools and the undergraduate course of a collegiate education. Boston: Hilliard, Gray and Company. 1834.

HEDSTRÖM, Peter; SWEDBERG, Richard; UDEHN, Lars. "Popper's Situational Analysis and Contemporary Sociology.” Philosophy of Social Sciences, 28(3): 339-364, 1998.

HOBBES, Thomas. "Elements of philosophy”. In: MOLESWORTH, William (ed.). The English works of Thomas Hobbes of Malmesbury. Londres: John Bohn. vol. I, 1839.

Leviatã. São Paulo: Martins Fontes, 2003.

HOMES JR, Oliver Wendell. The path of the law. 10 Harvard Law Review 457, 459 (1897).

HUTCHESON JR, Joseph C. The judgment intuitive: the function of the "hunch" in judicial decision. 39 S. Tex. L. Rev. 889 (1997-1998), pp. 889-903. 
JEVONS, William Stanley. The principles of economics. 3.ed. Londres: Macmillan \& Co,1888.

The principles of science: a treatise on logic and scientific method. 2 ed. Londres: Macmillam \& Co, 1913.

JHERING, Rudolf Von. A finalidade do direito. Campinas: Bookseller, 2002.

JOWETT, Benjamin. The dialogues of Plato translated into English with analysis and introductions. v.2, 3a ed. Oxford: 1892.

KELSEN, Hans. Teoria geral do direito e do estado. São Paulo: Marins Fontes, 2000. Teoria pura do direito. São Paulo: Martins Fontes, 2003.

KIERKEGAARD, Søren. Adquirir a sua alma pela paciência dos quatro discursos edificantes. Lisboa: Assírio \& Alvin, 2007.

KING, James E. The origin of the term "political economy". The Journal of Modern History, Vol. 20, No. 3. (Sep., 1948), pp. 230-231.

KNIGHT, Frank H. Risk, Uncertainty, and Profit. Boston: Houghton Mifflin Company, 1957.

“Social science.” Ethics, 83(1): 1-12, 1972.

KRUGMAN, Paul. Two cheers for formalism. The economic journal, 108, pp. 18291836, 1998.

LA METTRIE, Julien Offray De. Man a machine and man a plant. Hackett Publishing, 1994.

Le CD-ROM Du Grand Robert. Version électronique du Grand Robert de La langue française. Sejer, 2005.

LEWIS, Charlton T., SHORT, Charles. A latin dictionary. Oxford: Clarendon Press, 1958.

LIDELL, Henry George; SCOTT, Robert. A greek-english lexicom. OXFORD: Clarendon Press, 1996.

LIMA, Alvino. Da culpa ao risco. São Paulo: RT, 1938.

LINDLEY, Dennis. Making decisions. Londres: Wiley, 1971.

LOPES, José Reinaldo de Lima. O direito na história: lições introdutórias. São Paulo: Max Limonad, 2000. 
MACCORMICK, Neil. Argumentação jurídica e teoria do direito. São Paulo: Martins Fontes, 2006.

MACPHERSON, C. B. A economia política em hobbes. In MACPHERSON, C. B.. Ascensão e queda da justiça econômica e outros ensaios. o papel do estado, das classes e da propriedade na democracia do século XX. Rio de Janeiro: Paz e Terra, 1991.

MALTHUS, Thomas Robert. Observations on the effects of the corn laws, and of a rise or fall in the price of corn on the agriculture and general wealth of the country. Londres: Johnson \& Co, 1814.

MARKY, Thomas. Curso elementar de direito romano. 2. ed. São Paulo: Resenha Tributária, 1974.

MCCLOSKEY, Donald N. "The rethoric of economics". Journal of Economic Literature, vol 21, $\mathrm{n}^{\circ}$ 2, pp. 481-517, 1983.

MELE, Alfred. R., RAWLING, Piers. Aspects of rationality. In. MELE, Alfred. R.; RAWLING, Piers. (eds) Oxford handbook of rationality. Nova Iorque: Oxford University Press, 2003.

MILL, John Stuart. Essays on Some Unsettled Questions of Political Economy. Londres: Harrison and Co, 1844.

MORGENSTERN, Oskar. Limits to the use of mathematics in economics. Econometric research program. Research Memorandum No. 49. Princeton: Princeton University, 1963. Mimeo.

MOSSELMANS, Bert. Adolphe Quetelet, the average man and the development of economic methodology. European. Journal of History of Economic Thought 12:4 565 582 December 2005

NELSON, Julie. Feminism and economics. Journal of Economic Perspectives, v.9, n.2, 1995, p. 131-148.

NORTH, Douglass C. “Institutions.” Journal of Economic Perspectives, 5(1): 97-112, 1991.

Oxford Latin Dictionary. Oxford: Clarendon Press, 1968

PANTALEONI, Maffeo. Principii di economia pura. Torino: Ditta G.B. Paravia e C, 1889.

PARETO, Vilfredo. Considerations on the fundamental principles of pure political economy. Nova Iorque: Routledge, 2007.

PERELMAN, Chaïm. Lógica jurídica. São Paulo: Martins Fontes, 2004. 
Platão. Protágoras, Górgias, Fedão. 2a ed. Belém: EDUFPA, 2002.

POLANYI, Karl. A Grande Transformação. Rio de Janeiro: Elsevier, 2000.

POPPER, Karl R.. "Three Worlds.” The Tanner Lectures on Human Values delivered at The University of Michigan, 1978.

.. A Sociedade Aberta e seus Inimigos. Vol.2. Belo Horizonte: Itatiaia, 1998..

Conhecimento Objetivo. Belo Horizonte: Itatiaia, 1999.

A Lógica das Ciências Sociais. Rio de Janeiro: Tempo Brasileiro, 2004.

POPPER, Karl R; ECCLES, John C. The Self and its Brain: An Argument for Interactionsm. Nova Iorque: Routledge \& Kegan Paul, 1986.

PRIGOGINE, Ilya. O fim das certezas: tempo, caos e as leis da natureza. São Paulo: Unesp, 1996.

QUETELET, Adolph. A treatise on man and the development of his faculties. Edimburgo:William and Robert Chambers, 1842.

RADBRUCH, Gustav. Filosofia do direito. São Paulo: Martins Fontes, 2004.

REGIS Jr., Edward. “What is Ethical Egoism?” Ethics, 91(1): 50-62, 1980.

ROUSSEAU, Jean-Jacques. Discurso sobre a economia política e do contrato social. Petrópolis: Vozes, 1996.

RUBINSTEIN, Nicolai. The history of the word politicus in early-modern Europe. In. PAGDEN, Anthony. The languages of political theory in early Europe. Cambridge, Inglaterra: Cambridge University Press, 1990.

SALLER, Richard P. Pater famílias, mater famílias, and gendered semantics of the roman household. Classical Philology, vol. 94 (2), 1999, p.p182-197

SANTIAGO NINO, Carlos. Introducción al analisis del derecho. Buenos Aires: Astrea, 1980.

SAVAGE, Leonard J. The foundations of statistics. 2a. ed. Nova Iorque: Dover, $1954 .$.

SCHUMPETER, Joseph Alois. History of economic analysis. Routledge, 1986.

SEN, Amartya. "Rational fools: a critique of the behavioral foundations of economic theory”. Philosophy and public affairs $n^{\circ} 6,1977,99.317-44$.

Sobre ética e economia. São Paulo: Companhia das Letras, 2006. 
SIBLEY, W. M. The Rational versus the reasonable. The Philosophical Review, Vol. 62, No. 4. (Oct., 1953), pp. 554-560.

SOUZA, Fernando Menezes Campello de. Decisões racionais em situações de incerteza. 2 ed. Recife: 2007.

STIGLER, Stephen M. The history of statistics: the measurement of uncertainty before 1900. Cambridge: The Belknap Press, 1986.

SUPIOT, Alain. Homo juridicus: ensaio sobre a função antropológica do direito. São Paulo: Martins Fontes, 2007.

SWEDBERG, Richard. Max Weber e a Idéia de Sociologia Econômica. Rio de Janeiro: Editora UFRJ, 2005.

."Interpretive Economic Sociology: On the Relationship Between Max Weber's Basic Sociological Terms and his Economic Sociology.” Cornell University Center for the Study of Economic and Society. CSES Working Paper Series 29, 2005.

TELLEGEN-COUPERUS, Olga. A short history of roman law. Nova Iorque: Routledge, 2003.

TEUBNER, Gunther. Direito, sistema e policontextualidade. Piracicaba: UNIMEP, 2005, p. 233-268.

TEUBNER, Gunther; HUTTER, Michael. Homo juridicus and homo oeconomicus: communicative fictions? In: BAUMS, Theodor; HOPT, Baums, HORN, Norbert (eds.) 2000. Corporations, capital markets and business in the Law. Kluwer: Den Haag, pp. 569-584.

UDEHN, Lars. Methodological Individualism: Background, History and Meaning. Londres: Routledge, 2001.

"The Changing Face of Methodological Individualism." Annual Review of Sociology, 28: 479-507, 2002.

VELJANOVSKI, Cento. A economia do direito e da lei: uma introdução. Rio de janeiro: Instituto Liberal, 1994.

VEYNE, Paul. O império romano. In: VEYNE, Paul (org). História da vida privada. São Paulo: Companhia das Letras, 2009. v.1:do Império Romano ao ano mil. p.p. 17-42.

VILLEY, Michel. A formação do pensamento jurídico moderno. São Paulo: Martins Fontes, 2005.

WALD, Arnoldo. Direito das Obrigações. teoria geral das obrigações e contratos civis e comerciais. 15 ed. São Paulo: Malheiros, 2001. 
WALRAS, Léon. De l'application des mathématiques à l'économie politique. (1876). In: Revue française d'économie.Volume 4 N², 1989. pp. 145-173.

WATKINS, J. W. N. "The Principle of Methodological Individualism.” The British Journal for the Philosophy of Science, 3(10): 186-189, 1952a.

"Ideal Types and Historical Explanation." The British Journal for the Philosophy of Science, 3(9): 22-43, $1952 b$.

WEBER, Max. História agrária romana. São Paulo: Martins Fontes, 1994.

Economia e sociedade: fundamentos da sociologia compreensiva. $4^{\mathrm{a}}$ ed. São Paulo: Imprensa Oficial, v.1, 2004.

2006.

A “objetividade” do conhecimento nas ciências sociais. São Paulo: Ática,

WILLIAMSON, Oliver E. "Calculativeness, Trust, and Economic Organization." Journal of Law and Economics, 36(1): 453-486, 1993. 